\title{
Sensitive Resources Assessment and Forest Analysis for the Proposed Versatile Test Reactor, Oak Ridge, Tennessee
}

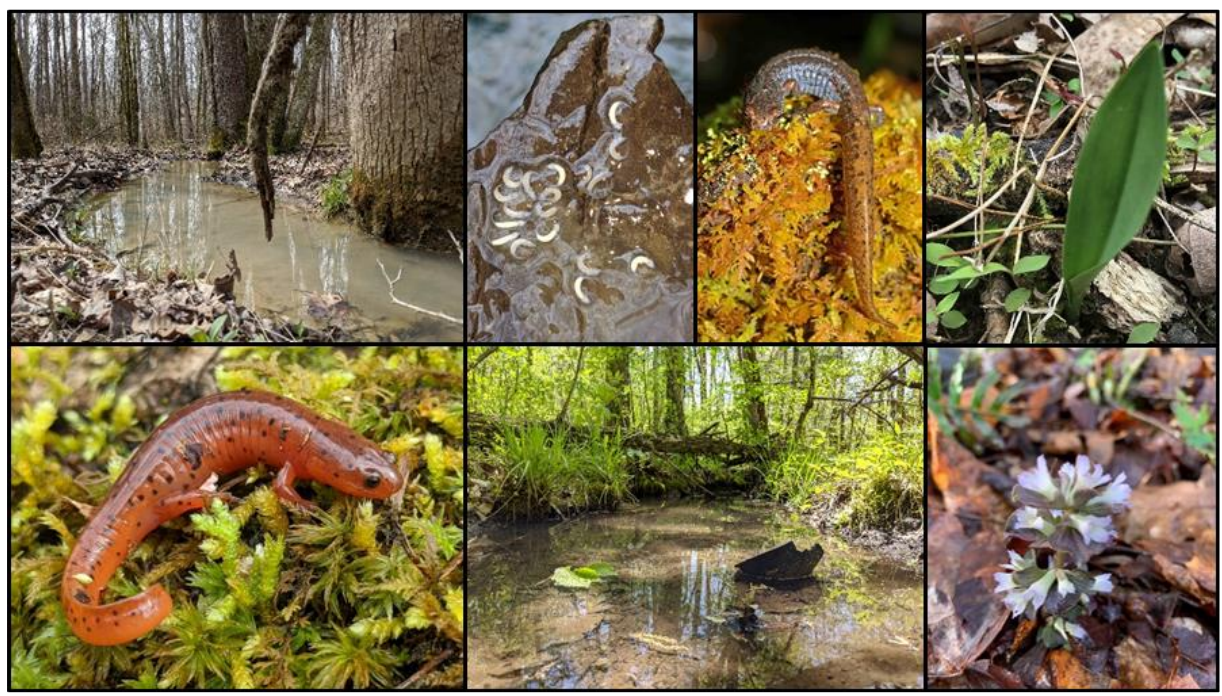

Approved for public release. Distribution is unlimited.

Evin Carter

Greg Byrd Jamie Herold Sara Darling Kitty McCracken Lindsey Hayter Bryce Wade Neil Giffen

September 2020 


\title{
DOCUMENT AVAILABILITY
}

Reports produced after January 1, 1996, are generally available free via US Department of Energy (DOE) SciTech Connect.

Website www.osti.gov

Reports produced before January 1, 1996, may be purchased by members of the public from the following source:

\author{
National Technical Information Service \\ 5285 Port Royal Road \\ Springfield, VA 22161 \\ Telephone 703-605-6000 (1-800-553-6847) \\ TDD 703-487-4639 \\ Fax 703-605-6900 \\ E-mail info@ntis.gov \\ Website http://classic.ntis.gov/
}

Reports are available to DOE employees, DOE contractors, Energy Technology Data Exchange representatives, and International Nuclear Information System representatives from the following source:

Office of Scientific and Technical Information

PO Box 62

Oak Ridge, TN 37831

Telephone 865-576-8401

Fax 865-576-5728

E-mail reports@osti.gov

Website http://www.osti.gov/contact.html

This report was prepared as an account of work sponsored by an agency of the United States Government. Neither the United States Government nor any agency thereof, nor any of their employees, makes any warranty, express or implied, or assumes any legal liability or responsibility for the accuracy, completeness, or usefulness of any information, apparatus, product, or process disclosed, or represents that its use would not infringe privately owned rights. Reference herein to any specific commercial product, process, or service by trade name, trademark, manufacturer, or otherwise, does not necessarily constitute or imply its endorsement, recommendation, or favoring by the United States Government or any agency thereof. The views and opinions of authors expressed herein do not necessarily state or reflect those of the United States Government or any agency thereof. 
Environmental Sciences Division

\title{
SENSITIVE RESOURCES ASSESSMENT AND FOREST ANALYSIS FOR THE PROPOSED VERSATILE TEST REACTOR, OAK RIDGE, TENNESSEE
}

\author{
Evin Carter $^{1}$ \\ Greg Byrd ${ }^{2}$ \\ Jamie Herold ${ }^{2}$ \\ Sara Darling ${ }^{2}$ \\ Kitty McCracken ${ }^{1}$ \\ Lindsey Hayter ${ }^{2}$ \\ Bryce Wade ${ }^{1}$ \\ Neil Giffen ${ }^{2}$
}

${ }^{1}$ Environmental Sciences Division

${ }^{2}$ Facilities and Operations Directorate

Natural Resources Management Program

Oak Ridge National Laboratory

Prepared for
Reactor and Nuclear Systems Division
Oak Ridge National Laboratory
$\&$
DOE - ORNL Site Office
Operations \& Oversight Division

September 2020

Prepared by

OAK RIDGE NATIONAL LABORATORY

Oak Ridge, TN 37831-6283

managed by

UT-BATTELLE, LLC

for the

US DEPARTMENT OF ENERGY

under contract DE-AC05-00OR22725 



\section{CONTENTS}

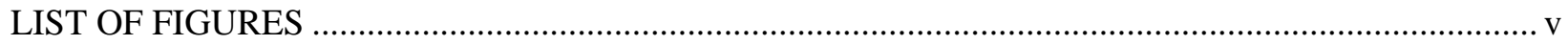

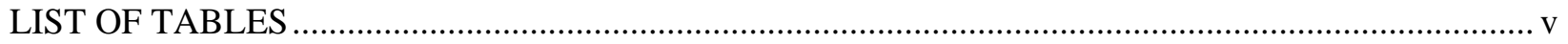

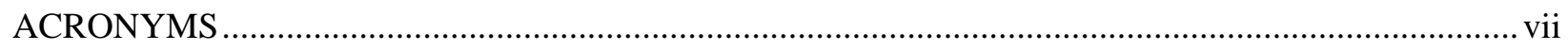

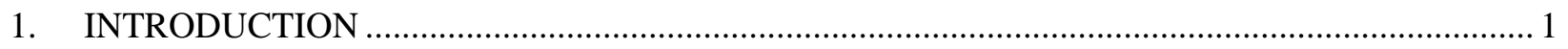

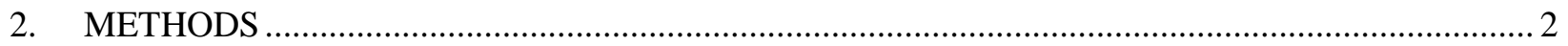

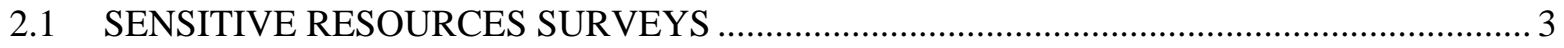

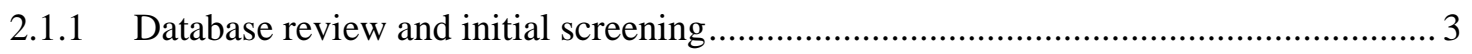

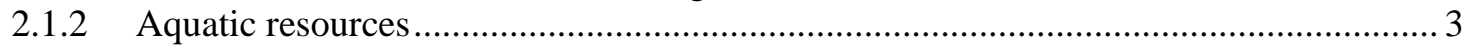

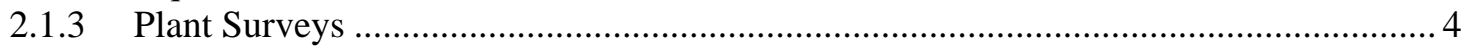

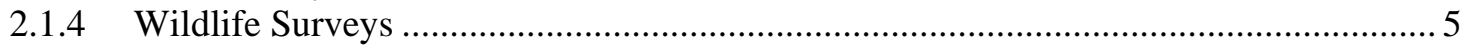

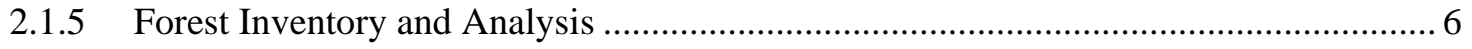

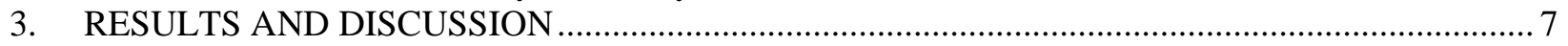

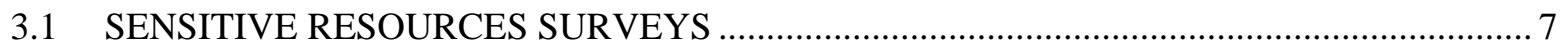

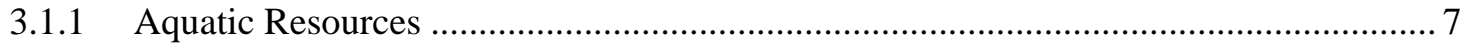

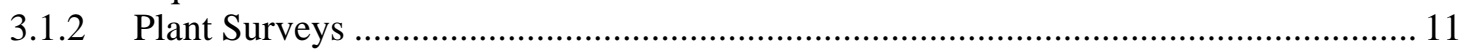

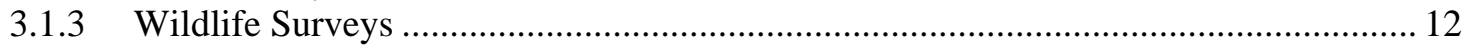

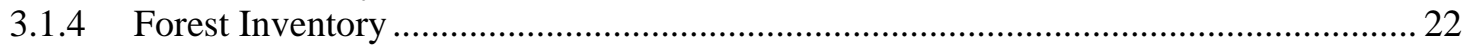

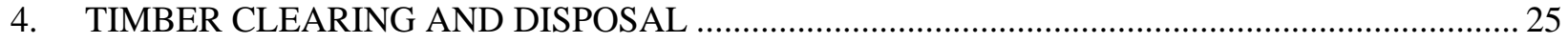

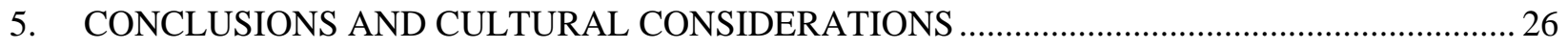

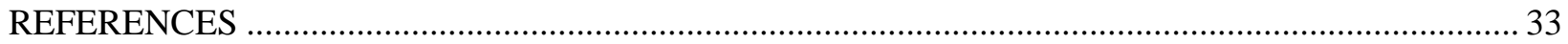

APPENDIX I. PRE-SURVEY SCREENING OF FEDERALLY LISTED TAXA, HABITAT SUITABILITY, AND HISTORICAL AND CONTEMPORARY PRESENCE WITHIN THE

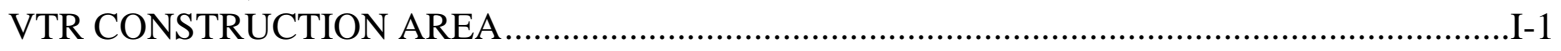

APPENDIX II. COMPLETE LIST OF VERTEBRATE WILDLIFE DOCUMENTED WITHIN

THE VTR CONSTRUCTION AREA ….................................................................................. II 1

APPENDIX III. ADDITIONAL DETAILS FROM 2013 FOREST INVENTORY ............................. III-1 



\section{LIST OF FIGURES}

Figure 1. Review area for the proposed VTR project on DOE's ORR, Oak Ridge, Tennessee, USA.

Figure 2. Previously assessed aquatic resources from the ORNL Natural Resources and

Environmental Sciences Division databases.

Figure 3. Aquatic resource review priority transects, color shaded according to connectivity to known sites of high natural area scores (updated with new data from Baranski 2009, 2011, 2018).

Figure 4. 2020 field-based stream mapping.....

Figure 5. 2020 field-based wetland mapping.

Figure 6. Field-mapped aquatic features overlaid on final model-based predictions of aquatic features.

Figure 7. Examples of flora encountered during 2020 field surveys.

Figure 8. All known locations within the vicinity of the VTR review area with records for stateor federal-listed bat species (see Table 2).

Figure 9. Examples of four-toed salamander (Hemidactylium scutatum) habitat within the VTR construction area and operations area footprints.

Figure 10. Four-toed salamander (Hemidactylium scutatum) core populations (brighter cores indicate larger population size) and dispersal corridors (darker reds indicate presence of barriers) on the ORR as modeled by the Circuitscape toolkit (McRae et al. 2013) with a compositive cost surface (vegetation height, soil saturation, infrastructure, and landscape "ruggedness") at $<1-\mathrm{m}$ raster cell resolution (adapted from Wade and Carter, 2020).

Figure 11. Left: Recently metamorphosed mud salamander (Pseudotriton montanus) observed on March 13, 2020 in a seep associated with Melton Brach and wetland MBNT1-5 in the VTR operations area.

Figure 12. Distribution of Pseudotriton spp in the White Oak Creek and Melton Branch watershed based on targeted survey from 2019 to 2020 .

Figure 13. 2011 forest inventory map for the proposed VTR site and vicinity. ................................... 24

Figure 14. Spatial distribution of land use types for the proposed VTR site. 24

\section{LIST OF TABLES}

Table 1. Results from acoustic bat detectors at the VTR survey area. Recordings are from May 15 to 21,2020 .

Table 2. Bat acoustic results from caves near the VTR project area from March 26 to April 2, 2020.

Table 3. Migratory birds recorded within the VTR construction area during 2020 field surveying........... 15

Table 4. Wildlife observed during 2020 visual encounter and nighttime call surveys (anurans).............. 21

Table 5. Overview of effects on known resources to result from development of the VTR and associated infrastructure. 



\section{ACRONYMS}

\begin{tabular}{ll} 
ARA & aquatic reference area \\
BCC & USFWS bird of conservation concern \\
bf & board feet (international 1/4 in. rule) \\
BMC & USFWS bird of management concern \\
CBSD & common bird in steep decline \\
DOE & US Department of Energy \\
dbh & diameter at breast height (4.5 ft) \\
ESA & US Endangered Species Act \\
ETW & Exceptional Tennessee Water \\
FS & ORNL Focal Species \\
HPRR & Health Physics Research Reactor \\
LiDAR & light detection and ranging \\
MA & in need of management action \\
MBTA & Migratory Bird Treaty Act \\
NERP & National Environmental Research Park \\
NM & In Need of Management by rule of TWRA \\
OSWDF & On-Site Waste Disposal Facility \\
ORNL & Oak Ridge National Laboratory \\
ORR & Oak Ridge Reservation \\
RC & regional concern \\
TDEC & Tennessee Department of Environment and Conservation \\
TRAM & Tennessee Rapid Assessment Method \\
TWRA & Tennessee Wildlife Resources Agency \\
USFWS & US Fish and Wildlife Service \\
VES & visual encounter survey \\
VTR & Versatile Test Reactor \\
WWC & wet weather conveyance \\
YWL & Yellow Watch List \\
\hline
\end{tabular}





\section{INTRODUCTION}

The US Department of Energy's (DOE's) Oak Ridge National Laboratory (ORNL) is a leading institution in advanced materials, supercomputing, neutrons, and nuclear science. As a research laboratory managed by UT-Battelle, LLC for DOE, ORNL has national priorities in energy, security, and scientific discovery that necessitate facility improvements and expansions. DOE is also committed to environmental stewardship. The laboratory is located on the $\sim 32,000$-acre ( 13,000-ha) Oak Ridge Reservation (ORR), much of which is categorized as a National Environmental Research Park (NERP) and a state Wildlife Management Area. DOE works with the Tennessee Wildlife Resources Agency (TWRA), Tennessee Department of Environment and Conservation (TDEC), US Fish and Wildlife Service (USFWS), US Department of Agriculture, and other agencies to serve as an effective steward of the ORR. Accordingly, project managers must conform to environmental regulations, agreements, and policies at the federal, state, and institutional levels. Per 40 CFR (Code of Federal Regulations) 1508.14, potential effects on research and science education also represent potential effects of federal actions on the NERP, and impacts on, e.g., deer harvest, must be considered on the Oak Ridge Wildlife Management Area when other aspects of the human environment are affected.

The United States currently has no fast neutron testing capability to support advanced nuclear research and development. The proposed Versatile Test Reactor (VTR) will take advantage of current investments by the US government and private industry in nuclear reactors to expedite the design and construction process, using proven technology to create a world-class scientific infrastructure. The VTR will take advantage of fast neutrons provided by this proven technology, along with a capability to rapidly insert, conduct, and remove state-of-the-art experiments. An advantage of the VTR is that it can support future innovations in experimental capabilities without modifying the facility. The VTR will support progress in a variety of science and technology areas, including testing and qualification of advanced reactor fuels; testing and qualification of innovative structural materials; testing of innovative components and instruments; validation of advanced modeling and simulation tools; and versatility for future technical missions. Through proven technology, the VTR can take advantage of existing reactor designs and operating experience to reduce the risk, cost, and time for design and construction. The top available resources of DOE laboratories, industry, and universities will be used to expedite reactor design and construction toward developing the scientific infrastructure that affords a strong testing capability that can be sustained over many years.

This report summarizes current knowledge of natural and cultural resources primarily within the VTR construction area. At the time of this report, the proposed VTR site design includes a construction area of $\sim 150.4$ acres ( 69.9 ha), which contains an $\sim 51.3$-acre ( 20.8-ha) operations area, located within forested natural areas of the ORR (Figure 1). The primary goal of the work presented here was to evaluate potential effects on sensitive resources that might result from development and construction activities associated with VTR. In addition to on-the-ground surveys during spring and summer 2020 by the ORNL Natural Resources Management Program and Aquatic Ecology Group staff, this report makes use of historical (pre-1995) and contemporary (1995 to present) data from additional confirmed sources (e.g., TDEC). Likewise, forest conditions were compiled from a 2011 forest inventory and supplemented with limited ground observations in 2020. The individuals who obtained and compiled the data presented here are familiar with and routinely assess sensitive resources on the ORR.

Anyone who references this report must consider that the timing of surveys did not permit a complete delineation of the resources that will be affected. If the VTR project proceeds, additional surveys will be required to account for the seasonal patterns of various threatened and endangered species. Data deficiencies and potential resources that likely went undetected are indicated where possible. Accordingly, this report should facilitate more environmentally sound decisions during planning and 
development of the VTR site, provide a foundation for further assessment of sensitive and cultural resources, and help project managers better address regulatory guidance and DOE policies on sustainable development in compliance with, for example, the US Endangered Species Act (ESA), Migratory Bird Treaty Act (MBTA), Tennessee Rare Plant Protection and Conservation Act of 1985, Tennessee Nongame and Endangered or Threatened Wildlife Species Conservation Act of 1974, several federal and state regulations regarding aquatic resource protection, and site-specific policies as outlined in various ORR management plans developed by ORNL and TWRA for DOE (e.g., Carter et al. 2020).

\section{METHODS}

Overview - In addition to on-the-ground surveys by ORNL Natural Resources Management Program and Aquatic Ecology Group staff, who routinely assess and are familiar with sensitive resources on the ORR, this report makes use of historical (pre-1995) and contemporary (1995 to present) data, as obtained from (1) previous reports and observations by ORNL Natural Resources, (2) reports made available to the ORNL Natural Resources Management Program by researchers and contractors on the ORR, and (3) TDEC's Natural Heritage Inventory Program. Historical observations (pre-1995) are especially relevant to quantify rare species, which are inherently difficult to detect. Thus, historical observations were presumed valid unless subsequent targeted surveys failed to detect those resources, and/or-in the case of sensitive flora and fauna - other resources that are critical to their persistence were no longer present or adequate to support viable populations with the VTR project area or connectivity between populations of sensitive taxa elsewhere on the ORR.

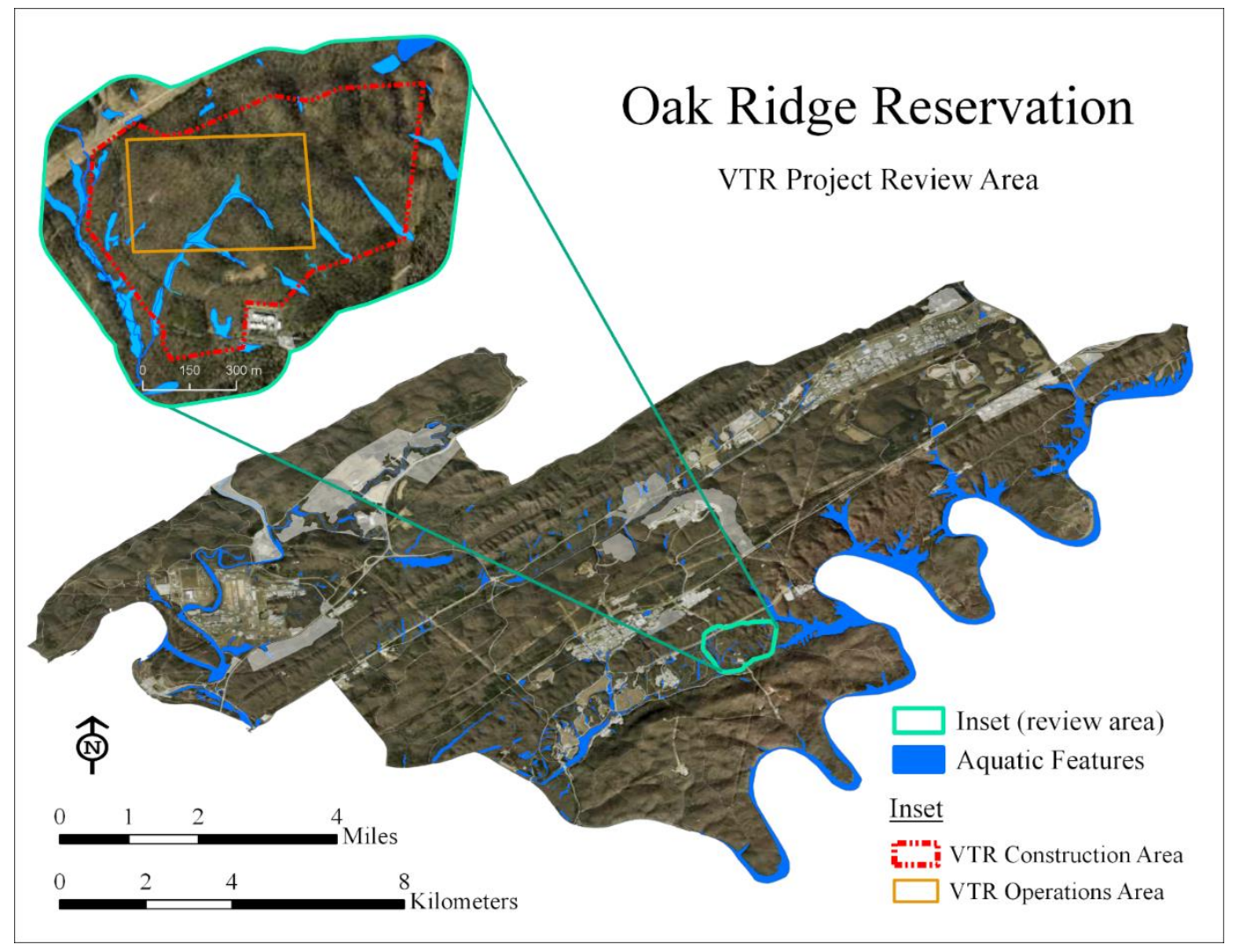

Figure 1. Review area for the proposed VTR project on DOE's ORR, Oak Ridge, Tennessee, USA. 


\subsection{SENSITIVE RESOURCES SURVEYS}

\subsubsection{Database review and initial screening}

Species-specific habitat inventory - We compiled a list of endangered, threatened, rare, or otherwise sensitive focal taxa with potential to occur within the VTR construction area. We first reviewed the ORNL natural resources database for spatial records of sensitive resources confirmed within the vicinity of the review area. These taxa were considered contemporary records if they were documented after 1995. All others were considered unconfirmed historical records unless later survey confirmed their presence within the VTR construction area. We then compiled a list of additional sensitive resources with reasonable potential to occur within the VTR construction area based on occurrence elsewhere on the ORR, rare and sensitive resources known to occur within the Tennessee counties of Anderson and Roane as identified through TDEC's online Rare Species database (http://environmentonline.state.tn.us:8080/pls/enf reports/f? $\mathrm{p}=9014: 3: 0$ ), and resources identified by USFWS's Information for Planning and Consultation tool (https://ecos.fws.gov/ipac/), using the VTR construction area footprint as the input area. Habitat parameters for each of the potential sensitive resources were compiled through the same sources (Appendix I). These parameters were later used to help guide field-based survey and data collection.

\subsubsection{Aquatic resources}

Environmental management and protection of aquatic features on the ORR is a priority for DOE and thus a major focus of several divisions within ORNL. Accordingly, substantial efforts have been made on inventory and understanding the connectivity of surface and subterranean aquatic features (Figure 2). Thus, we first reviewed previous aquatic resource delineation efforts and reports to determine locations of known streams, wetlands, and seeps within the VTR construction area (e.g., Rosensteel, 1996; Baranski 2011, 2018). We then used these data alongside new quantitative hydrology models to focus current fieldbased mapping. Field-mapped seeps/springs, stream, and wetland boundaries presented here represent aquatic features within and adjacent to the VTR construction area that were mapped by an experienced hydrologic technician via a Trimble Geo 7x. However, this preliminary assessment did not include complete wetland delineations or stream determinations, which will be required by TDEC if the VTR project proceeds as currently planned. Additional detailed procedures for the preliminary aquatic feature assessment are outlined in the following paragraphs.

Modeling hydrology within the VTR construction area-The many capabilities at ORNL in advanced geographic information system mapping and modeling that have occurred since the original mapping efforts allowed us to focus on potential new wetlands, shallow ephemeral pools, streams, and wet weather conveyances (WWCs). Specifically, LiDAR (light detection and ranging) data at $<1-\mathrm{m}$ resolution were obtained from a winter 2015/2016 flyover (USGS 2015, 2016) of the ORR. These data-in conjunction with an inventory of 3,442 seeps, active springs, sinks, and caves within the ORR by the ORNL Natural Resources Program - were used to develop several hydrologic models. These models included surface water flow to identify streams and WWCs by catchment area via the hydrology toolset in ArcMap 10.7 (ESRI 2018), and surface porosity (owing to karst features) via a diffusion model with elevation as a cumulative barrier in $\mathrm{R}$ version 4.0.2 ( $\mathrm{R}$ Core Team, 2020). The extensive inventory of macropores and other karst windows were used to either add or subtract from surface water according to their depth relative to the water table at originally mapped resolutions. These models were used to focus the fieldbased surveys herein via stream, wetland, and soil saturation predictions for the VTR construction area. 


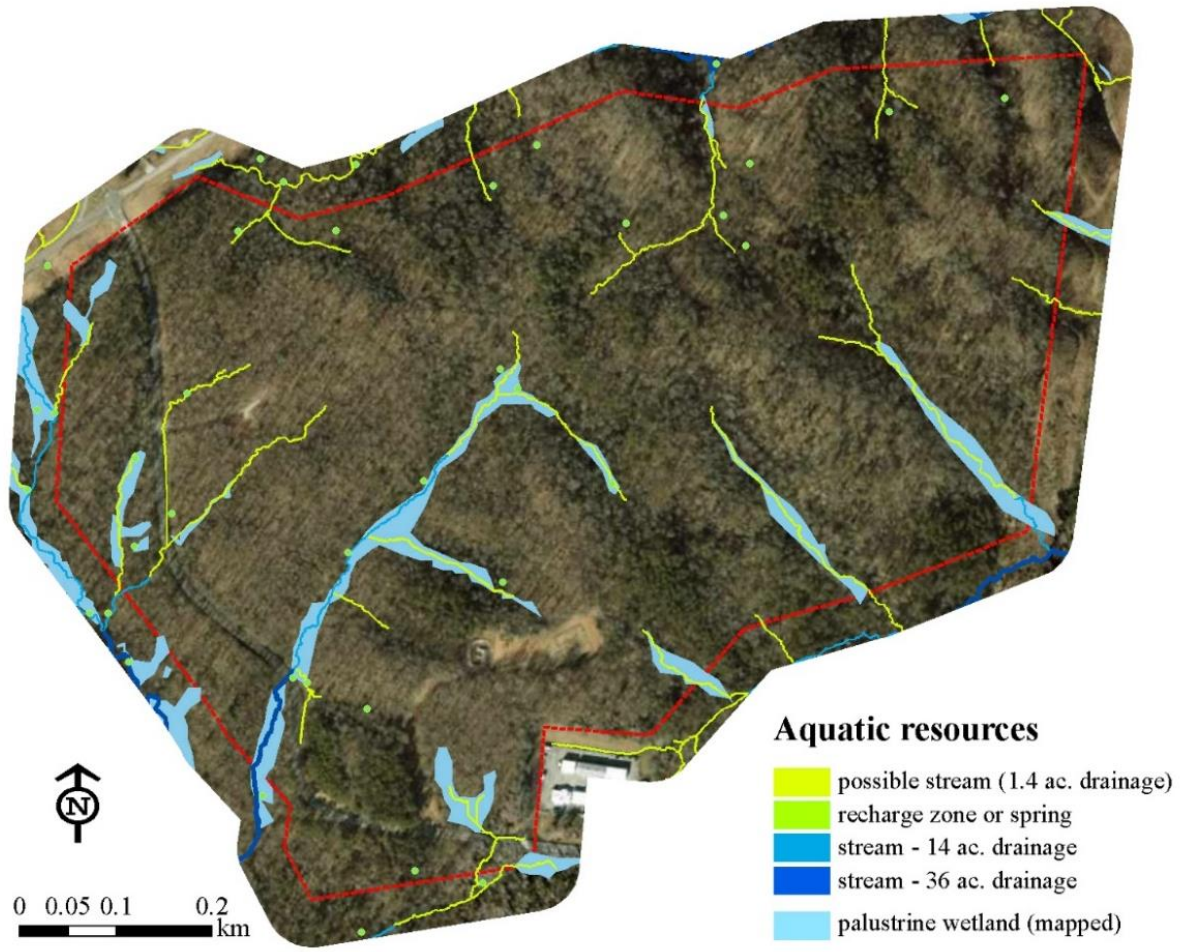

Figure 2. Previously assessed aquatic resources from the ORNL Natural Resources and Environmental Sciences Division databases. Wetlands are based on a 1999 inventory of wetlands on the ORR, springs are based on ongoing field inventory, and streams and drainages are based on remote-sensing efforts by the ORNL

Environmental Sciences Division at $<1-\mathrm{m}$ resolution (LiDAR, aerial imagery, and satellite imagery), followed by ground delineations. Results of contemporary mapping efforts are included in Section 3.3.1.

Field-based aquatic feature inventory within the VTR construction area-Aquatic surveys were conducted between February and July 2020. Wetland surveys that required plant identification were predominantly conducted in May or June 2020. When possible, surveys for sensitive aquatic or semiaquatic species were conducted at the best time to locate those species. Additional details pertaining to wildlife and plant surveys can be found in Sections 2.1.3 and 2.1.4.

Integrating field and model based delineations - Newly acquired data were used to retrain models as new data were collected. We used updated maps to document the extensive aquatic resources within the proposed VTR site, gain a clear picture of the aquatic connectivity in this area, and understand their relation to other sensitive resources such as stream or wetland obligate flora and fauna.

Field-mapped seeps/springs and stream and wetland boundaries presented here do not represent complete wetland delineations and stream determinations. Instead, they represent aquatic features within and adjacent to the VTR construction area that were mapped by an experienced hydrologic technician via a Trimble Geo 7x. New data on plants and other unique natural features were also collected during aquatic feature surveys.

\subsubsection{Plant Surveys}

Plant surveys were conducted between May and July 2020 when vegetation could most easily be identified. Any potential rare species that could not be positively identified given the time frame of this study were documented and will be monitored through the remaining growing season. These species mainly include taxa that require blooms to identify beyond genus or species that are inconspicuous when 
not flowering. Rare plant surveys were conducted primarily to confirm the presence or absence of suitable habitat for taxa with state or federal listing status. Existing maps and reports revealed no previously documented rare plants within the review area. Therefore, surveys prioritized habitats identified through the initial screening of sensitive resources with potential to occur within the VTR project area (see Section 2.1.1). During this initial screening, we determined that the review area has suitable habitat for multiple plant species that are threatened, endangered, or of otherwise special interest. In particular, surveys focused on federally listed Virginia spiraea (Spiraea virginiana) and white fringeless orchid (Platanthera integrilabia), and the state-listed tubercled rein orchid (Platanthera flava var. herbiola). All three species have known occurrences either on the ORR or the surrounding area. Additional rare plant species with potentially suitable habitat can be found in Appendix I. Dominant vegetation was also recorded while surveying wetlands, streams, and ridgetop locations.

\subsubsection{Wildlife Surveys}

Bat acoustic surveys-Bats are a primary focus of the ORNL Natural Resources Program because the ORR's forests, wetlands, and caves have the potential to support several state- and federal-listed bats. Of the bats on the ORR (McCracken et al. 2015), the Indiana bat (Myotis sodalis) and gray bat (Myotis grisescens) are listed by USFWS as federally Endangered, and the northern long-eared bat (Myotis septentrionalis) is listed as federally Threatened under ESA. Additionally, the little brown bat (Myotis lucifugus) and tricolored bat (Perimyotis subflavus) are currently under federal review for listing under ESA. All federally listed bats and several additional bats of the ORR carry various special protection statuses specific to the state of Tennessee (see Appendix I for details).

Six bat acoustic monitors (Wildlife Acoustics Song Meter SM4Bat FS Ultrasonic Recorders equipped with SMM-U2) were positioned in likely flyways and foraging zones throughout or immediately adjacent to the survey area from 15-21 May, 2020. Sites for acoustic recording were selected based on likelihood of use by bats as flyways to foraging grounds and/or for foraging. Microphones were mounted on 3-m poles and directed along the likely flyway. Recording began 30 min before sunset and ended 30 min after sunrise each night. All SM4Bat monitors were deployed for seven consecutive nights, beginning May 15, 2020. Additionally, four cave entrances were surveyed using bat acoustic monitors as described. Caves that may serve as hibernacula for federal- or state-listed bat species and are within 2 miles of the survey area were selected. Cave surveys were conducted from 26 March-2 April, 2020. Monitors were placed close to cave entrances to record calls of bats as they exited for nightly foraging. Data were collected and analyzed using Kaleidoscope Pro Analysis Software, version 5 with both zero-crossing and full-spectrum analysis methods, as approved by USFWS.

Bird point counts-Migratory birds also represent a major management focus for ORNL and DOE. For example, Carter (2020) provides details related to DOE's responsibilities specific to the ORR, and the 2013 memorandum of understanding between USFWS and DOE can be found at https://www.energy.gov/sites/prod/files/2013/10/f3/Final\%20DOEFWS\%20Migratory\%20Bird\%20MOU.pdf.

To assess occupancy and potential importance of the site by migratory birds, we combined historical species occurrence primarily via ongoing Partners in Flight surveys across the ORR. To provide a more detailed assessment specific to VTR, we also implemented avian point counts at 12 equally spaced locations within the VTR construction area. All bird species seen or heard within a period of $10 \mathrm{~min}$ at each point were recorded. The first six points were surveyed on 7 May 2020, and the last six points were surveyed on 6 July 2020. We also recorded birds seen or heard opportunistically during visual encounter surveys (VESs). 
$V E S s$-We implemented VESs along all streams, wetlands, and ridgetops within the review area three times between February and July 2020. We focused on the topographic/habitat extremes because the preliminary review indicated that potential sensitive flora and fauna within the review area were associated either with aquatic or ridgetop features or were more easily detected via alternative methods (Figure 3). VES transects were generated in ArcMap 10.7 (ESRI, 2018) based on previous habitat and aquatic resource mapping efforts (Rosensteel 1996; Baranski 2009, 2011, 2018). Transects and search methods were prioritized according to their level of connectivity (e.g., hydrologic or contiguous natural area) to areas with known records of rare and sensitive wildlife outside of the VTR construction area (Wade and Carter 2020; Wade, DeRolph, and Carter, in preparation). However, search areas were adjusted in the field according to current conditions and to prioritize those habitats identified through the initial screening of sensitive resources (Section 2.1.1). All wildlife encountered were recorded and photographed where possible, and surveyors maintained an active inventory of rare and sensitive species' habitat suitability by referencing the previously compiled list of potential rare and sensitive taxa (see Section 2.1.1 and Appendix I).

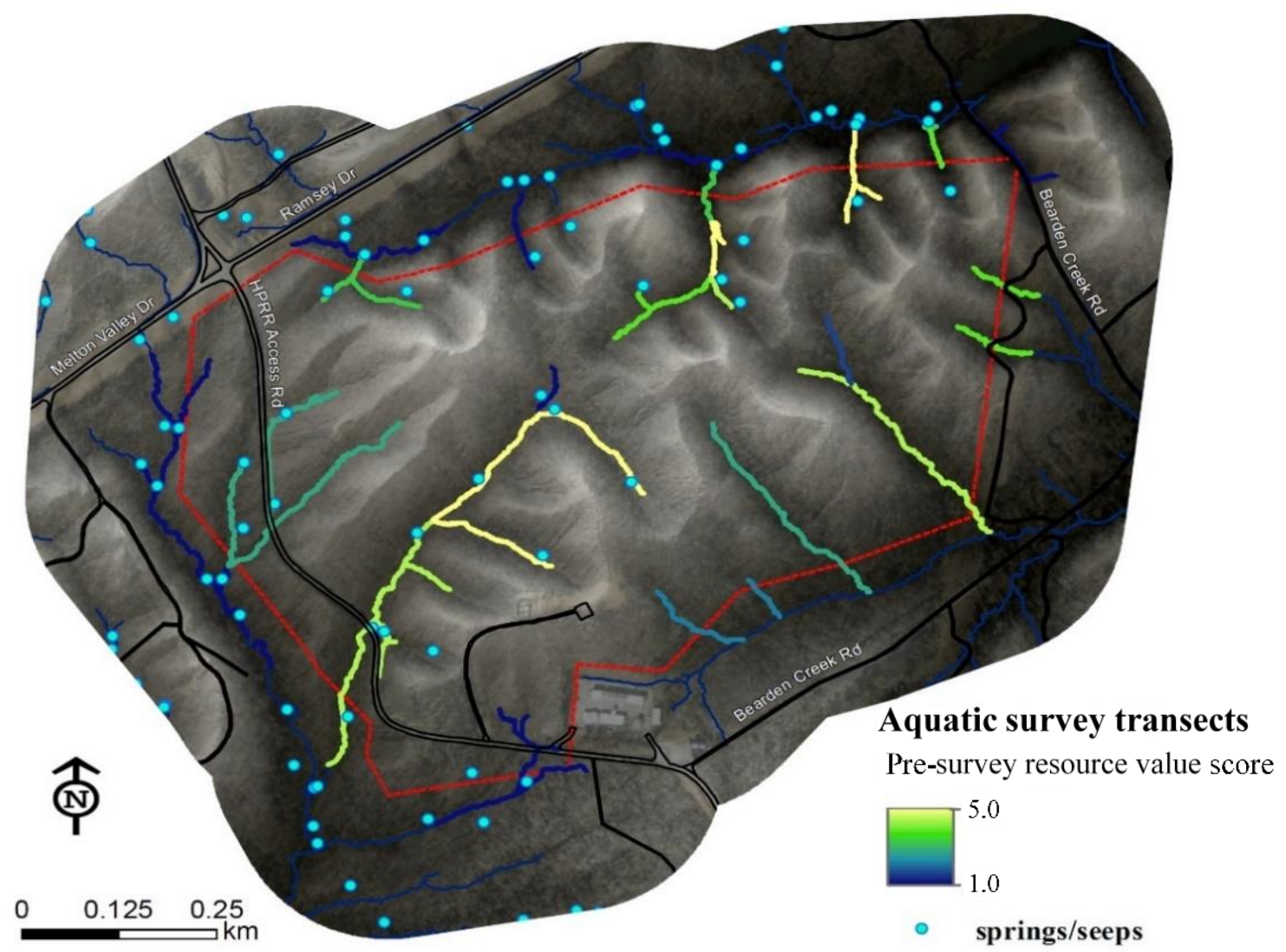

Figure 3. Aquatic resource review priority transects, color shaded according to connectivity to known sites of high natural area scores (updated with new data from Baranski 2009, 2011, 2018). Background: the lightest and darkest background areas (composite grayscale wetness/terrain exposure overlay) received the highest search efforts during VESs. The darkest areas are more likely to contain wetlands and streams, and the lightest areas represent ridgetops.

\subsubsection{Forest Inventory and Analysis}

Forest conditions were assessed based on previous forest inventory and contemporary ground observations. A forest inventory for Forest Management Compartment 21, which contains the VTR 
review area, was concluded in September 2011 (Johnston, unpublished report to the ORNL Natural Resources Management Program).

\section{RESULTS AND DISCUSSION}

\subsection{SENSITIVE RESOURCES SURVEYS}

\subsubsection{Aquatic Resources}

Seeps, springs, and WWCs - The VTR construction area contains $\geq 30$ seeps/active springs and extensive WWCs (Figures 4 and 5). Because springs are inherently difficult to assess, they were mapped as point features near their source. Additional surveys will be required if the VTR project proceeds.

Streams - Approximately 1,490 ft (454 m) of mapped streams are within the VTR construction area. This does not include currently unclassified channels and WWCs that will require hydrological determinations (Figure 4). The VTR construction area is drained by Melton Branch and Bearden Creek. The first- and second-order reaches of Melton Branch in the construction area eventually become a major tributary of the main stem of White Oak Creek, an aquatic system contained within the ORR that drains into the Clinch River. Sections of Melton Branch and White Oak Creek are part of the Biological Monitoring and Abatement Program that was established in the 1980s (Baranski 2009, 2011), and portions of Melton Branch and its riparian buffer zone and wetlands comprise the Melton Branch Aquatic Reference Area (ARA). ARAs were established on the ORR to protect special habitats and serve as reference or control areas for various ecological monitoring, research, and remediation activities. Impacts to Melton Branch or its associated catchment, tributaries, or wetlands might represent a significant impact to sensitive resources and decades of biological monitoring and research at ORNL. 


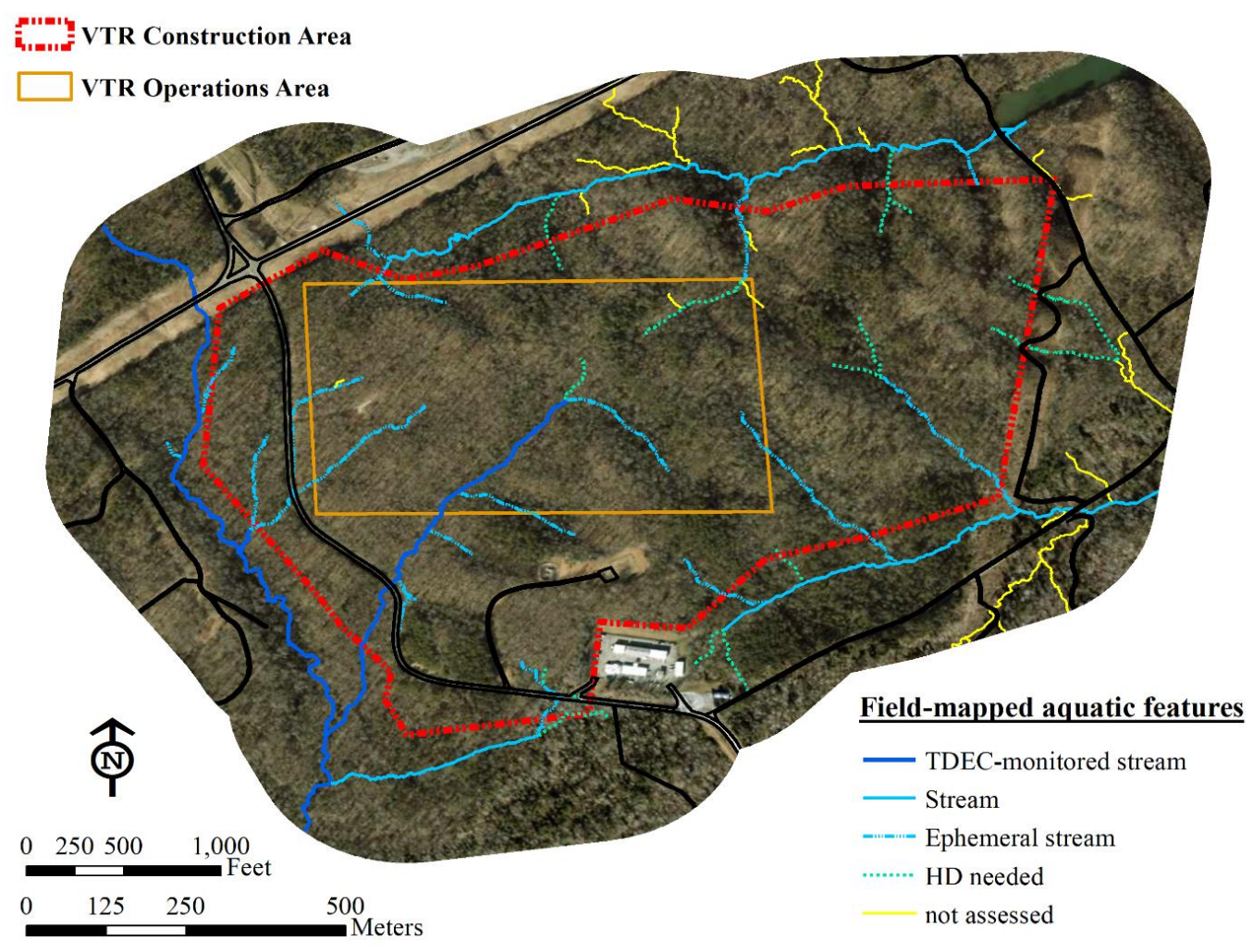

Figure 4. 2020 field-based stream mapping. Wetlands included in the Melton Branch ARA are indicated by dark blue (TDEC-monitored stream). This ARA (wetlands and tributaries included) serve as a decades-long research and reference sampling area for multiple DOE/ORNL programs.

Wetlands-Approximately 7.3 acres (2.95 ha) of previously mapped wetland occur within the VTR construction area. Field surveys documented an additional 0.8 acres ( $0.32 \mathrm{ha})$ of previously unmapped wetland for a total of $>8.1$ acres (3.3 ha). Wetlands were associated with tributaries, drainages, and topographic depressions (Figures 5 and 6). All wetlands in the footprint are classified as palustrine forested broad-leaved deciduous wetlands (PFO1) (Cowardin et al. 1979). Wetlands within the Melton Branch system were associated primarily with the stream and accompanying drainages at the bottom of steep sloped ravines, although some were located in lower elevation areas near the road. These wetlands are a mosaic of unvegetated alluvial flats, herbaceous vegetation, shrubs, and trees. Woody vegetation was located primarily along the wetland edges and along streams. Bearden Creek wetlands were associated with ravines but had a more complex network of drainages and WWCs (Figure 6). Two newly documented wetlands contained large populations of brown widelip orchid and over 50 Jack-in-the-pulpit plants. Another wetland in this system contained a similar sized population of Jack-in-the-pulpit, but these were predominantly female plants that were substantially taller, reaching heights between 2 and $3 \mathrm{ft}$. The latter plant characteristics are usually indicative of an area with nutrient rich soils that can support the additional energy it takes the female plant to bear fruit. Although neither brown widelip orchid nor Jackin-the-pulpit are considered rare, these abbreviated surveys suggest that wetlands within the VTR construction area are characteristic of systems that support less common species or communities.

Wetlands within the VTR construction are likely to be deemed Exceptional Tennessee Waters (ETWs) owing to (1) their history and utility in ORNL/DOE research and compliance sampling programs, (2) the presence of the only known state-listed four-toed salamanders (Hemidactylium scutatum) south of the ORNL campus (on the ORR), (3) the presence of the only known mud salamanders, an ORNL Focal Species (FS) for research and management, in Roane or Anderson County Tennessee (Carter et al. 2020; 
Carter and Wade 2020), and (4) probable occurrence of state- and/or federally listed orchids (i.e., Platanthera flava var. herbiola and/or Platanthera integrilabia).

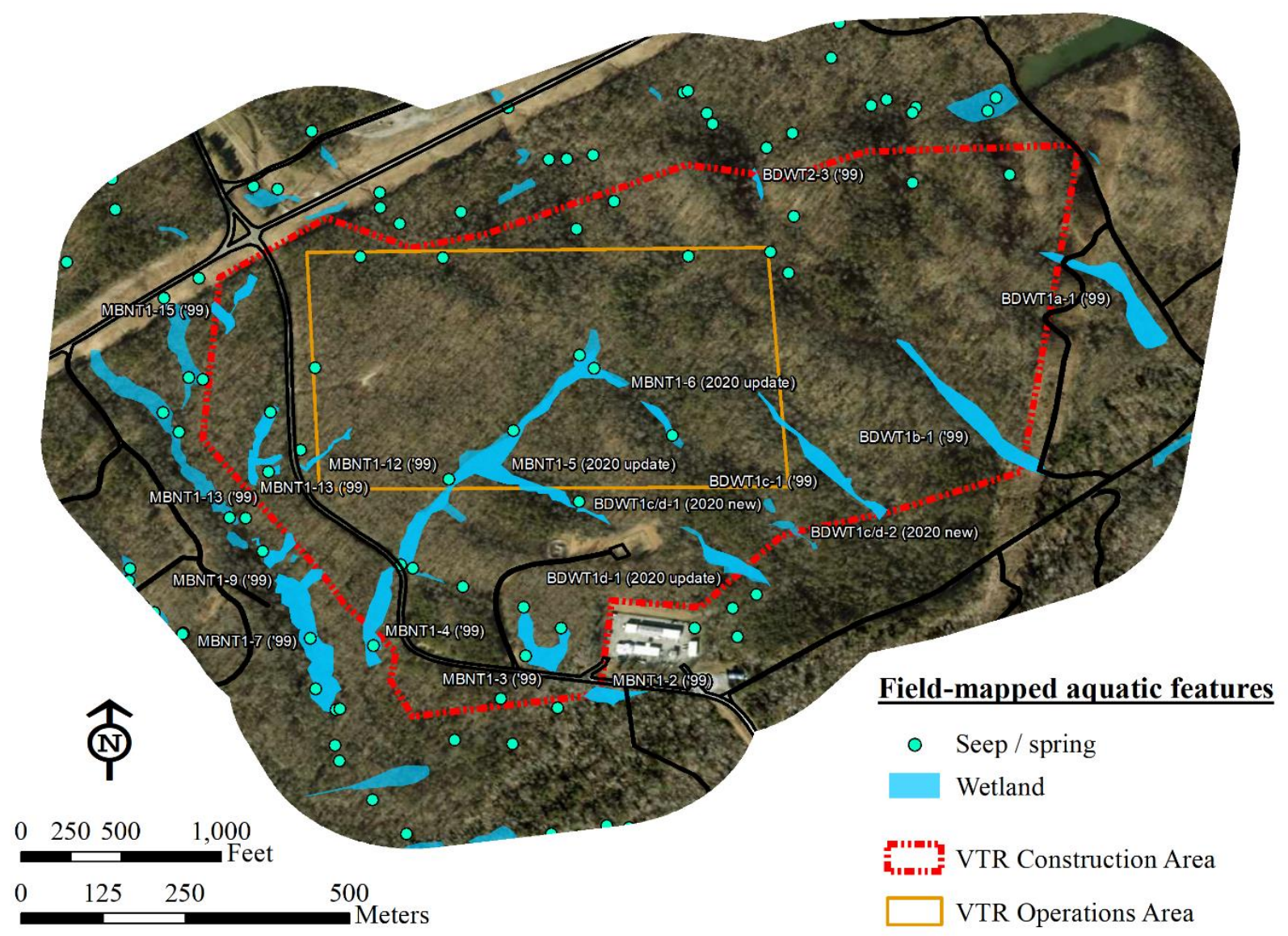

Figure 5. 2020 field-based wetland mapping. Wetlands included in the Melton Branch ARA contain the prefix MBTN. This ARA serves as a decades-long reference sampling area for multiple DOE/ORNL programs.

Additional regulatory considerations - ETWs are aquatic resources with features that merit special attention or consideration and are significant at the national, state, or regional level. An ETW designation is expected for aquatic features within the VTR construction and operations areas (Figures 4-6). The ETW designation is determined via the Tennessee Rapid Assessment Method (TRAM), a tool designed by TDEC for mitigation planning (TDEC 2015). The requirements for a wetland to be considered ETW are outlined in Rule 0400-40-03-.06(4)a of the TDEC General Water Quality Criteria (TDEC Chapter 0400-40-03, 2015). If this project proceeds, additional assessment will be required. Minimally, this would include wetland delineations (USACE 1987), stream evaluations (TDEC 2019), and hydrologic determinations of currently unclassified channels and WWCs (TDEC 2020). Any potential ETW will require the additional assessment using TRAM (TDEC 2015). 


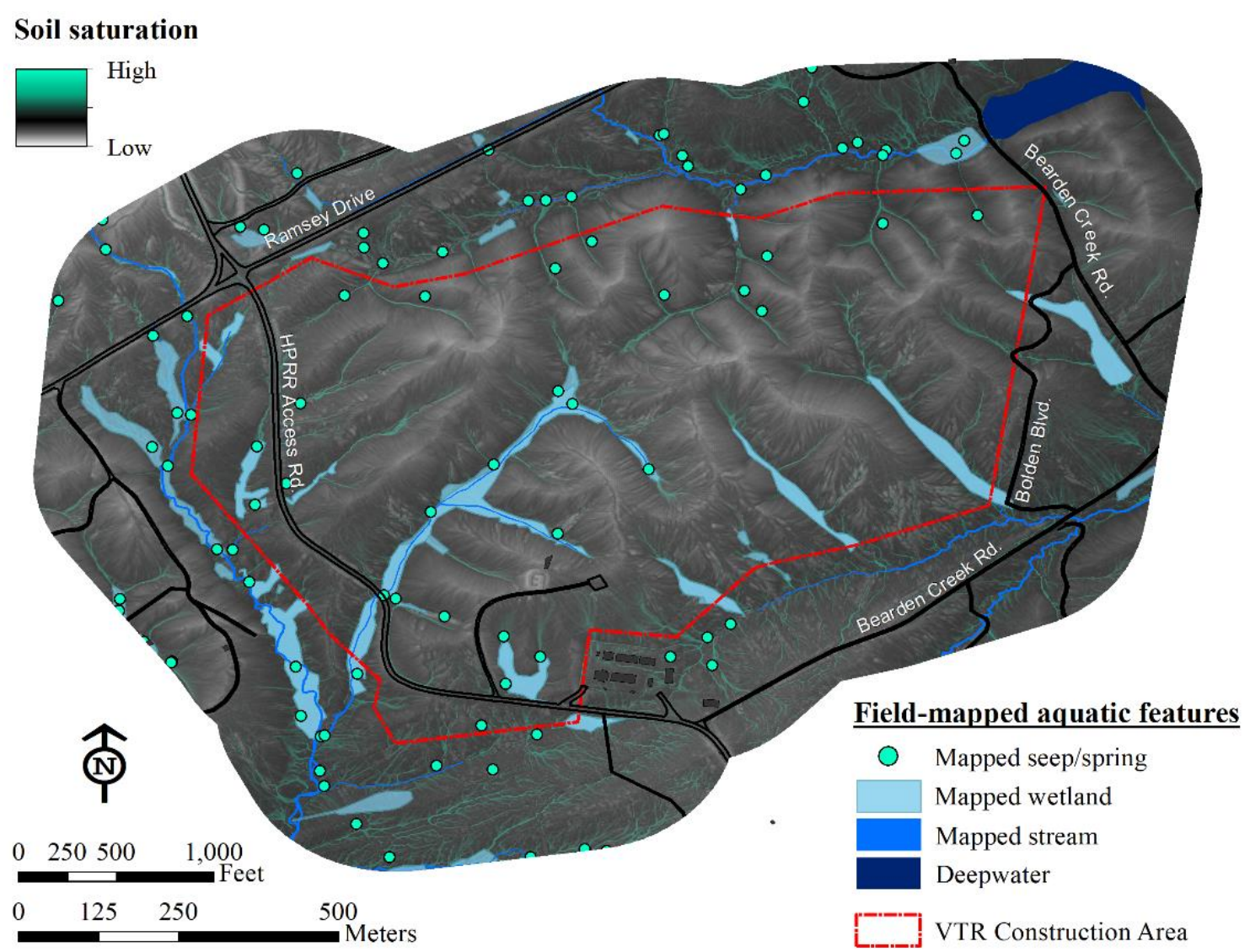

Figure 6. Field-mapped aquatic features overlaid on final model-based predictions of aquatic features. Delineated streams represent perennial streams only. Ephemeral and intermittent streams are shown in Figure 4 but strongly agree with soil saturation predictions here. Those streams will also require hydrologic determination and potential mitigation under TDEC regulation if they are affected by VTR construction.

Mitigation-Evaluation of aquatic resources at proposed mitigation sites might be required to assess adequate mitigation actions (TDEC, 2019; TDEC, 2015). Mitigation ratios are broadly defined as 2:1 for restoration, 4:1 for creation/enhancement, and 10:1 for preservation. For ETW, TDEC often prefers that equivalent quality habitat within the same watershed be placed into permanent conservatorship (preservation) and at rates higher than non-ETW. A preliminary look at the Melton Branch watershed suggests that the headwaters and upper reaches of Melton Branch represent the only areas within the Melton Branch or White Oak Creek watershed considered to be Reservation Clean Areas, and, even so, similar headwater seep and mucky riparian wetlands do not exist elsewhere in the Melton Branch watershed. Importantly, sensitive aquatic features occur throughout and adjacent to the VTR construction area, but the most substantial wetlands and stream environments occur within the planned VTR operations area (Figures 4-6). Moreover, the nearest known similar combination of wetland features on the ORR (in terms of quantity, structure, and species composition) is subject either to future development or to alternative land use plans. Thus, additional efforts would be required to assess the full scale of effects and to determine appropriate mitigation strategies given the number, complexity, and quality of aquatic resources (i.e., wetlands, streams, and conveyances) within the review area. The ORNL Natural Resources Program is equipped for such assessment should the project proceed. 


\subsubsection{Plant Surveys}

Individual orchids were identified within the VTR construction area during spring and early summer 2020 as possible Platanthera flava var. herbiola (state-listed Threatened) and/or Platanthera integrilabia (listed Threatened under ESA). However, individuals could not be positively identified given seasonal growth patterns and the abbreviated period that was provided to conduct surveys. Additional longer-term surveying of these populations is necessary to determine impacts.

Although no rare plants were positively identified as of the timing of 1 August 2020, suitable habitat for Virginia spiraea, white fringeless orchid, and tubercled rein orchid were recorded for future reference. Additional rare and sensitive plant species that have potential habitat within the VTR project area are listed in Appendix I. Plant communities of management or research importance to the ORNL Natural Resources Program or Environmental Sciences Division were also documented during plant field surveys. A dense population of brown widelip orchids (Liparis liliifolia) were located in a wetland associated with Bearden Creek. Although not a federal- or state-listed species, the population consisted of $>30$ individuals. Wide-lip orchid populations of this size are otherwise unknown on the ORR or surrounding area. The species is known to occur with only occasional frequency in East Tennessee (Chester, et al. 2015) and is listed as threatened or endangered in multiple eastern US states (USDA NRCS, 2016). At least five other orchid species occur within the VTR construction area, which highlights the extent and variability of moist soil habitat within the construction area.

The VTR construction area primarily comprises forested wetlands with intervening steep slopes and drymesic ridgetops. The majority of plant community data was collected within aquatic areas and lowerelevation areas during wetland surveys. Specific tree species data and basal area can be found in Section 3.1.4. Upland herbaceous vegetation included common woodland species such as rattlesnake plantain, bedstraws, Virginia creeper, Christmas fern, Japanese honeysuckle, false Solomon's seal, and white avens. Dominant understory vegetation in the forested wetlands included saplings of red maple, sweetgum, sycamore, green ash, ironwood; understory trees and shrubs, including ironwood, spicebush, and strawberry bush; and herbaceous species, including bulbus cardimine, false nettle, marsh violet, sensitive fern, polygonum, poison ivy, rice cutgrass, Microstegium, hog peanut, jewelweed, agrimony, and multiple hydrophytic sedge and grass species. Additional species included pawpaw, Jack-in-thepulpit, foam flower, and brown widelip orchid. Several representative plants found within the VTR construction area are shown in Figure 7. 


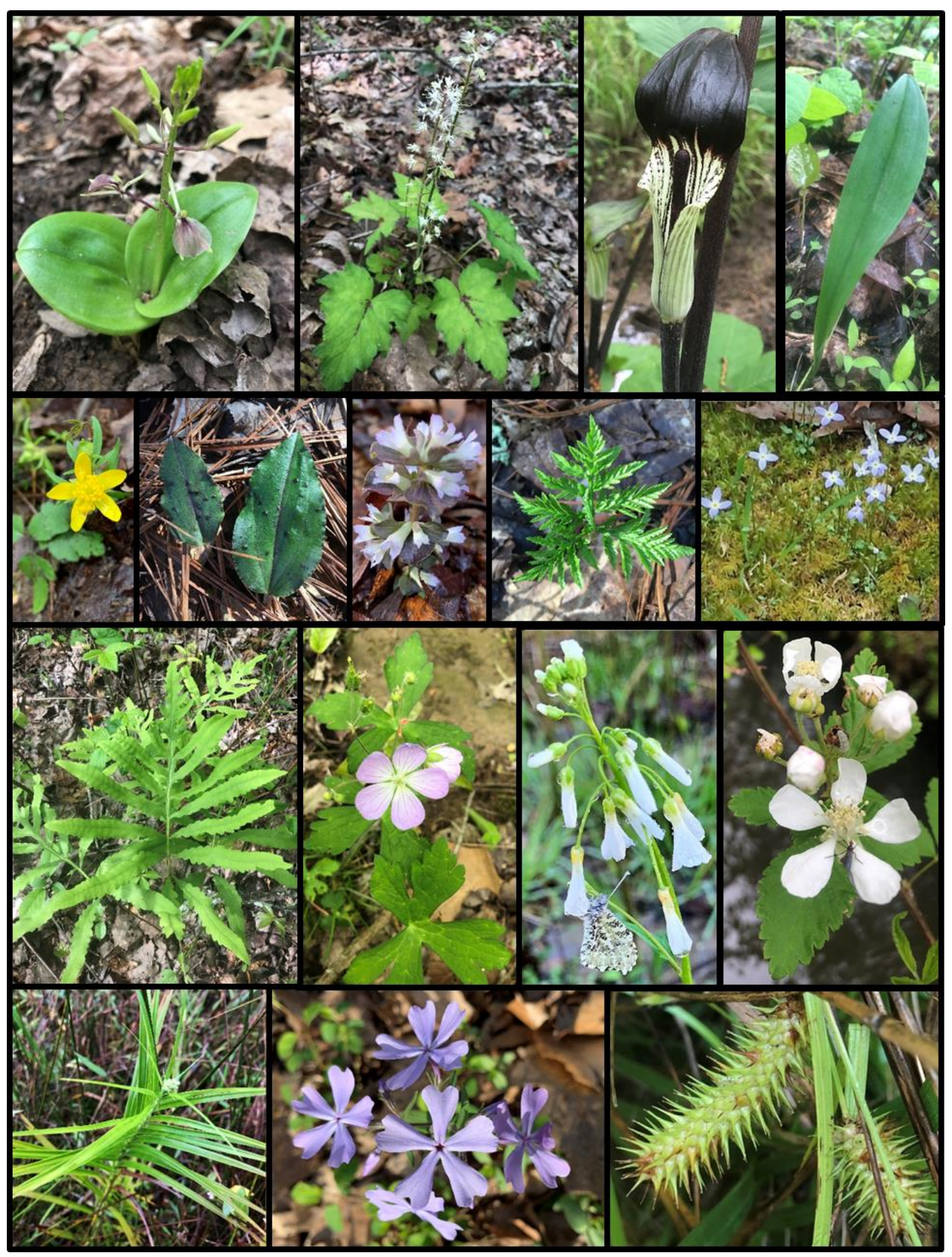

Figure 7. Examples of flora encountered during 2020 field surveys.

\subsubsection{Wildlife Surveys}

Bat acoustic surveys (70 survey nights)—Results from bat acoustic detectors (Figure 8) are included in Tables 1 and 2. In total, 15 native bat species were detected at cave entrances. Of these, detection frequencies provide strong evidence of the occurrence of 10 species, reasonable evidence of 4 species, and 1 species was considered unlikely at cave entrances near the VTR survey area. Of the 12 native bat species detected at the VTR survey area, detection frequencies provide strong evidence of 6 species, 
reasonable evidence of 3 species, and 3 species were considered unlikely within the survey area. Both state- and federally listed species - including federally Endangered gray bats (Myotis grisescens), state Threatened little brown bats (Myotis lucifugus), and state Threatened tricolored bats (Perimyotis subflavus) (also under federal review) - were detected at a relatively high frequency within the survey area and at cave entrances. Three additional species with state and/or federal listing status were considered probable residents given either moderate detection frequency or incidental observation that occurred outside of the 2020 survey (Tables 1 and 2).

Table 1. Results from acoustic bat detectors at the VTR survey area. Recordings are from 15-21 May 2020. The number of call detections is included for each detector. A low number of detections is considered poor evidence of presence. (SR: considered rare or regionally important by the state of Tennessee; SD: state-listed In Need of Management; ST: state-listed Threatened; SE: state-listed Endangered; FT: federally Threatened; FE: federally Endangered; UR: federal listing status currently Under Review).

\begin{tabular}{|c|c|c|c|c|c|c|c|c|c|}
\hline \multirow{2}{*}{ Species } & \multirow{2}{*}{$\begin{array}{l}\text { Ref. } \\
\text { site }\end{array}$} & \multicolumn{6}{|c|}{ VTR forest/wetlands } & \multirow{2}{*}{$\begin{array}{c}\text { Suspected } \\
\text { impact }\end{array}$} & \multirow{2}{*}{ Status } \\
\hline & & $\begin{array}{l}\text { VTR-1 } \\
\end{array}$ & VTR-2 & VTR-3 & VTR-4 & VTR-5 & VTR-6 & & \\
\hline Myotis grisescens & 1050 & 6 & 1 & 84 & 0 & 0 & 10 & Yes & FE, SE \\
\hline Myotis lucifugus & 2 & 24 & 97 & 16 & 0 & 4 & 182 & Yes & UR, ST \\
\hline Myotis septentrionalis & 0 & 0 & 0 & 0 & 0 & 0 & 1 & Uncertain & FT, ST \\
\hline Myotis sodalis & 1 & 0 & 1 & 0 & 0 & 1 & 0 & Uncertain & FE, SE \\
\hline Perimyotis subflavus & 0 & 11 & 0 & 64 & 0 & 1 & 2 & Yes & $\mathrm{UR}, \mathrm{ST}$ \\
\hline Eptesicus fuscus & 202 & 2 & 3 & 6 & 0 & 2 & 1 & & \\
\hline Lasiurus borealis & 143 & 21 & 9 & 392 & 0 & 2 & 42 & & \\
\hline Lasiurus cinereus & 79 & 11 & 9 & 1 & 0 & 7 & 16 & & \\
\hline Lasiurus seminolus & 286 & 0 & 0 & 0 & 0 & 0 & 0 & & \\
\hline Lasionycteris noctivagans & 380 & 13 & 11 & 4 & 0 & 11 & 6 & & \\
\hline Myotis leibii & 0 & 0 & 0 & 0 & 0 & 1 & 1 & Uncertain & SD \\
\hline Nycticeius humeralis & 61 & 12 & 3 & 5 & 0 & 3 & 0 & & \\
\hline Tadarida brisiliensis & 699 & 4 & 4 & 0 & 0 & 6 & 0 & & \\
\hline
\end{tabular}

Table 2. Bat acoustic results from caves near the VTR project area from 26 March - 2 April 2020. Only bat species that may hibernate in caves and are state- or federal-listed are included in this table.

\begin{tabular}{lcccccc}
\hline \multicolumn{1}{c}{ Species } & Cave 1 & Cave 2 & Cave 3 & Cave 4 & Suspected impact & Status \\
\hline Myotis grisescens & 32 & 5 & 461 & 119 & Additional survey required & FE, SE \\
Myotis lucifugus & 54 & 1 & 22 & 23 & Additional survey required & UR, ST \\
Myotis septentrionalis & 89 & 2 & 92 & 66 & Additional survey required & FT, ST \\
Myotis sodalis & 22 & 0 & 48 & 23 & Additional survey required & FE, SE \\
Perimyotis subflavus & 23 & 8 & 24 & 63 & Additional survey required & UR, ST \\
\hline
\end{tabular}

Note: See Table 1 for explanation of status codes. 


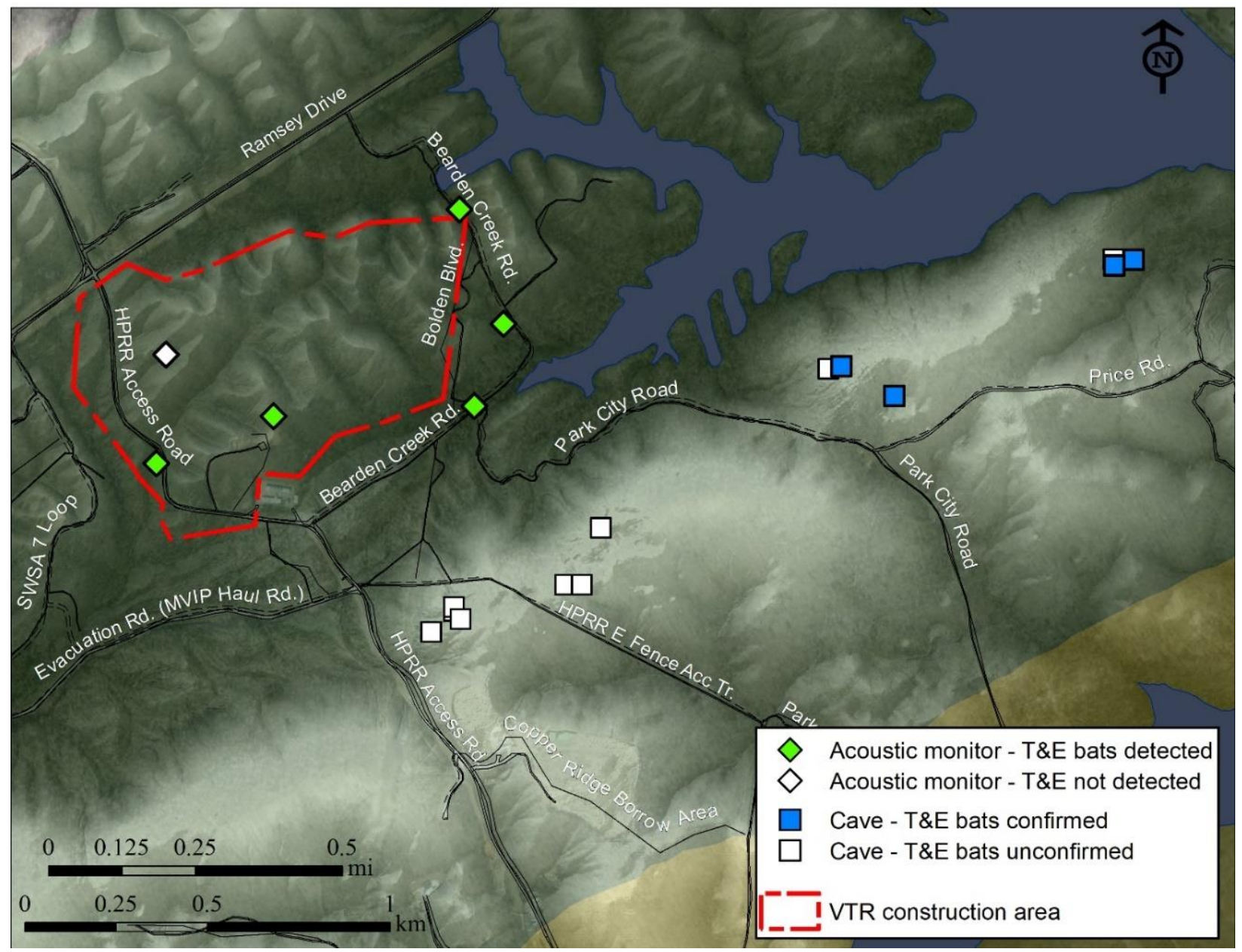

Figure 8. All known locations within the vicinity of the VTR review area with records for state- or federallisted bat species (see Table 2). Green diamonds depict bat detector locations with positive detections of threatened and endangered bats $(n=5)$, and the single white diamond represents a detector with zero calls detected (possibly due to a malfunctioning unit). Blue squares represent caves with both acoustic and visual confirmation of threatened or endangered bat activity (e.g., visual surveys, fresh guano), and white squares represent caves with potential for bat activity but that were not confirmed through visual or acoustic survey.

Bird point counts (13 person-hours) —In total, 46 bird species were identified from March to July 2020 from approximately 13 survey hours of survey efforts. These species included 46 taxa protected under MBTA, with 1 species listed by the TWRA as In Need of Management (NM; TCA $\S \S 70-1-206,70-8$ 104, 70-8-106, and 70-8-107, TWRA 2018), 3 species considered by USFWS to be birds of conservation concern (BCCs), 5 species considered by USFWS to be birds of management concern (BMCs), and one ORNL focal species for research and management. Additionally, nine species were considered by Partners in Flight to be species of regional concern (RC) and in need of management action (MA), there was one common bird in steep decline (CBSD), and one species was on the Yellow Watch List (YWL) (Table 3). No other state- or federally listed bird species were detected. Additional migratory birds and $\mathrm{BCC}$ and BMC taxa known from the VTR review area are included in Appendices I and II. 
Table 3. Migratory birds recorded within the VTR construction area during 2020 field survey. Additional migratory birds are known from the site. All vertebrate fauna known from the VTR construction area are included in Appendix II.

\begin{tabular}{|c|c|c|c|c|c|}
\hline Common name & Scientific name & Federal status & $\begin{array}{l}\text { State } \\
\text { status }\end{array}$ & $\begin{array}{l}\text { Partners in } \\
\text { Flight status }\end{array}$ & Notes \\
\hline Acadian flycatcher & Empidonax virescens & & & $\mathrm{RC}, \mathrm{MA}$ & Migrant, summer \\
\hline American crow & Corvus brachyrhynchos & & & & Year-round \\
\hline American goldfinch & Spinus tristis & & & & Year-round \\
\hline American robin & Turdus migratorius & & & & Year-round \\
\hline Barred owl & Strix varia & & & & Year-round \\
\hline Blue jay & Cyanocitta cristata & & & & Year-round \\
\hline Blue-gray gnat-catcher & Polioptila caerulea & & & & Migrant, summer \\
\hline Blue-winged warbler & Vermivora cyanoptera & $\mathrm{BCC}, \mathrm{BMC}$ & & & Migrant, summer \\
\hline Brown thrasher & Toxostoma rufum & & & & Migrant, summer \\
\hline Brown-headed cowbird & Molothrus ater & & & & Migrant, summer \\
\hline Canada goose & Branta canadensis & $\mathrm{BMC}$ & & & Migrant, summer \\
\hline Carolina chickadee & Poecile carolinensis & & & & Year-round \\
\hline Carolina wren & $\begin{array}{l}\text { Thryothorus } \\
\text { ludovicianus }\end{array}$ & & & & Year-round \\
\hline Downy woodpecker & Dryobates pubescens & & & & Year-round \\
\hline Eastern phoebe & Sayornis phoebe & & & & Migrant, summer \\
\hline Eastern towhee & Pipilo erythrophthalmus & & & $\mathrm{RC}, \mathrm{MA}$ & Migrant, summer \\
\hline Eastern wood-pewee & Contopus virens & & & $\mathrm{RC}, \mathrm{MA}$ & Migrant, summer \\
\hline Field sparrow & Spizella pusilla & & & $\begin{array}{l}\text { CBSD, RC, } \\
\text { MA }\end{array}$ & Migrant, summer \\
\hline Hooded warbler & Setophaga citrina & & & & Migrant, summer \\
\hline Indigo bunting & Passerina cyanea & & & & Migrant, summer \\
\hline Kentucky warbler & Geothlypis formosa & $\mathrm{BCC}, \mathrm{BMC}$ & & & Migrant, summer \\
\hline Mourning dove & Zenaida macroura & BMC & & & Year-round \\
\hline Northern cardinal & Cardinalis cardinalis & & & & Year-round \\
\hline Northern flicker & Colaptes auratus & & & $\mathrm{RC}, \mathrm{MA}$ & Migrant, summer \\
\hline Northern parula & Setophaga americana & & & & Migrant, summer \\
\hline Osprey & Pandion haliaetus & & & & Migrant, summer \\
\hline Ovenbird & Seiurus aurocapilla & & & & Migrant, summer \\
\hline Pileated woodpecker & Dryocopus pileatus & & & & Year-round \\
\hline Pine warbler & Setophaga pinus & & & & Migrant, summer \\
\hline Red-bellied woodpecker & Melanerpes carolinus & & & & Year-round \\
\hline Red-eyed vireo & Vireo olivaceus & & & & Migrant, summer \\
\hline Red-shouldered hawk & Buteo lineatus & & & & Year-round \\
\hline Red-tailed hawk & Buteo jamaicensis & & & & Year-round \\
\hline Rose-breasted grosbeak & Pheucticus ludovicianus & & & $\mathrm{RC}, \mathrm{MA}$ & Migrant, summer \\
\hline $\begin{array}{l}\text { Ruby-throated } \\
\text { hummingbird }\end{array}$ & Archilochus colubris & & & & Migrant, summer \\
\hline Scarlet tanager & Piranga olivacea & & & & Migrant, summer \\
\hline Summer tanager & Piranga rubra & & & $\mathrm{RC}, \mathrm{MA}$ & Migrant, summer \\
\hline Swainson's thrush & Catharus ustulatus & & & & Migrant, summer \\
\hline Tufted titmouse & Baeolophus bicolor & & & & Year-round \\
\hline White-breasted nuthatch & Sitta carolinensis & & & & Year-round \\
\hline White-eyed vireo & Vireo griseus & & & & Migrant, summer \\
\hline
\end{tabular}


Table 3. Migratory birds recorded within the VTR construction area during 2020 field survey (continued). Additional migratory birds are known from the site. All vertebrate fauna known from the VTR construction area are included in Appendix II.

\begin{tabular}{|c|c|c|c|c|c|}
\hline Common name & Scientific name & Federal status & $\begin{array}{c}\text { State } \\
\text { status }\end{array}$ & $\begin{array}{l}\text { Partners in } \\
\text { Flight status }\end{array}$ & Notes \\
\hline Wild turkey & Meleagris gallopavo & & & & Year-round \\
\hline Wood thrush & Hylocichla mustelina & $\begin{array}{c}\text { USFWS Focal } \\
\text { Species, BCC, } \\
\text { BMC, FS }\end{array}$ & $\mathrm{NM}^{*}$ & YWL, RC, MA & Migrant, summer \\
\hline Yellow warbler & Setophaga petechia & & & & Migrant, summer \\
\hline Yellow-breasted chat & Icteria virens & & & $\mathrm{RC}, \mathrm{MA}$ & Migrant, summer \\
\hline Yellow-throated warbler & Setophaga dominica & & & & Migrant, summer \\
\hline
\end{tabular}

Federal status codes: MBTA: protected under the Migratory Bird Treaty Act; BCC: USFWS Bird of Conservation Concern; MC: USFWS Bird of Management Concern

State status codes: NM: In Need of Management by rule of TWRA (TWRA 2018)

Partners in Flight status codes: CBSD: Common Bird in Steep Decline; YWL: Yellow Watch List; RC: Regionally

Important; MA: Management Attention needed

VESs (75 person-hours)-Based on VESs within the VTR construction from February to July 2020, we observed 9 reptile species ( 8 squamates and 1 turtle), 16 amphibian species ( 8 anurans and 8 caudates), and 12 mammals species. We also recorded several eyeless isopods (Caecodotea $\mathrm{sp}$ ) from a spring at the southeast corner of the review area. Based on lack of pigment and absence of eyes, specimens were identified as likely Caecodotea incurva/recurvata, considered Rare by TDEC (Table 4). Additional vertebrate taxa known from the VTR construction area based on preliminary database review (see Section 2.1.1) are included in Appendix II.

Most notably among vertebrate fauna, breeding populations and active nests of four-toed salamanders (Hemidactylium scutatum) were found in wetlands and mucky streams within the VTR construction area and operations area footprints (Figure 9). This species is listed as In Need of Management by the state of Tennessee and represents an ORNL FS owing to its highly specialized breeding biology-a requirement for unique bog or muck wetlands with abundant mats of moss that are used for oviposition and egg development. The species is highly sensitive to even minor changes in hydroperiod because eggs develop in moss immediately over water until hatching as aquatic larvae (Pasachnik and Niemiller 2011). The VTR construction area serves as a considerable source $(\sim 33 \%)$ of all known four-toed salamanders on the ORR based on around two seasons of extensive sampling and population connectivity modeling efforts (Figure 10, Wade and Carter 2020).

An additional FS for research and management, the mud salamander (Pseudotriton montanus), occurs at low detection frequency within the isolated seeps and springs in the VTR construction area and operations area, particularly along headwater streams with mucky substrates (Figure 11). Two juvenile mud salamanders - one observed near the center of wetland MBNT1-5 on 13 March 2020, and one observed near the extreme southwest edge of MBNT1-5 on 30 March 2020 (see Figure 5 for wetland IDs) represent the first and only mud salamanders recorded and verified on the ORR or in Roane County Tennessee (Figures 11 and 12). The individuals were officially verified by A. Floyd Scott of The Center for Field Biology, Austin Peay State University, and catalogued as APSU20008 (photo vouchers in the Atlas of Amphibians in Tennessee). Although mud salamanders were not previously known from Anderson County or Roane County, the ORNL Natural Resources Program expected that they occur within select uncontaminated mucky wetlands and seeps on the ORR, and considerable efforts were made to locate populations within the White Oak Creek and Melton Branch watersheds from February to July 2020 and the Bear Creek watershed from March 2019 to July 2020. Thus far, red salamanders are known 
from several headwater streams and seeps throughout the White Oak, Melton Branch, and Bear Creek watersheds, whereas mud salamanders have been identified only within wetland MBTN1-5 (Figure 12).

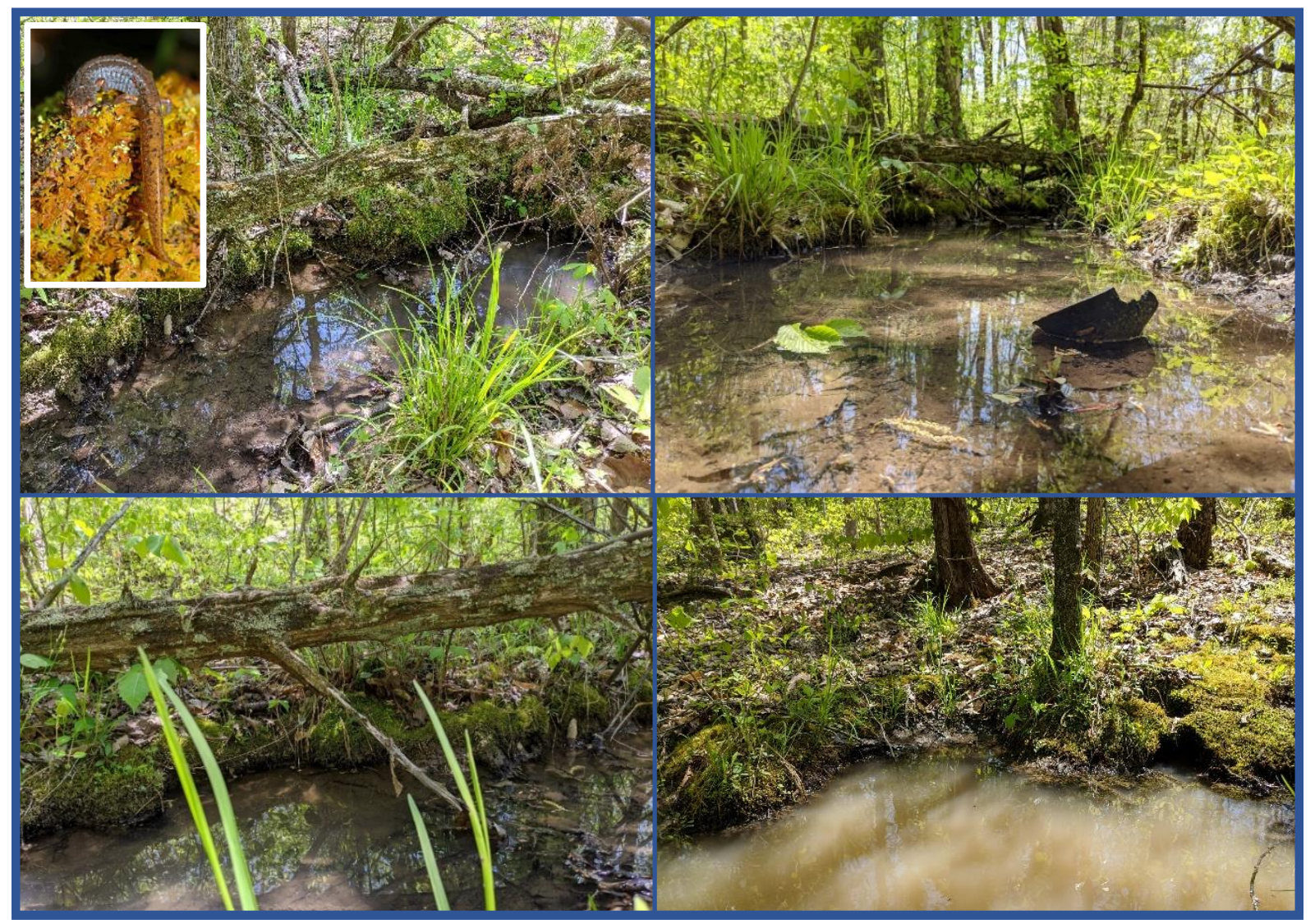




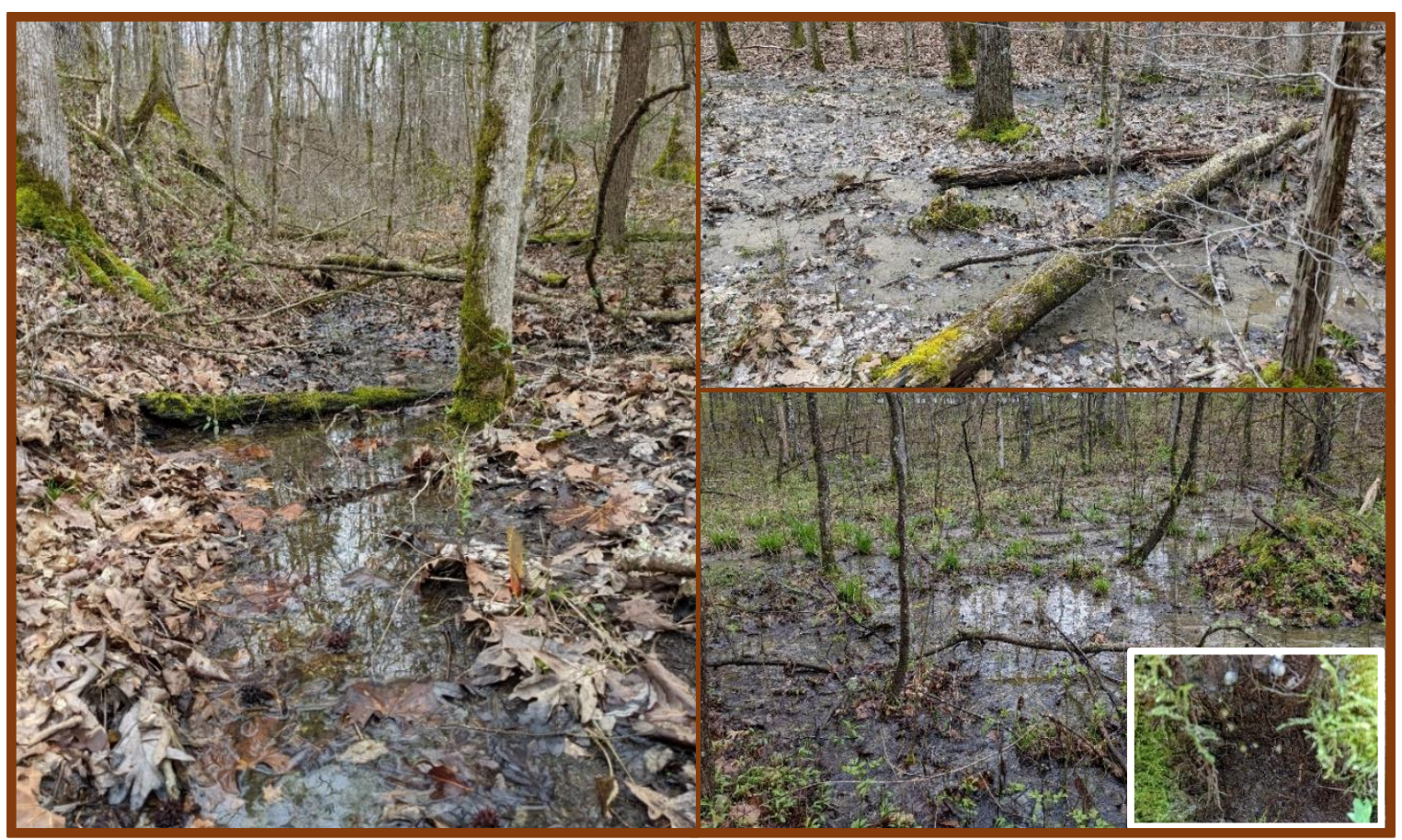

Figure 9. Examples of four-toed salamander (Hemidactylium scutatum) habitat within the VTR construction area and operations area footprints. Top group: Wetlands associated with Bearden Creek; top left inset: adult four-toed salamander. Bottom group: wetlands associated with Melton Branch; Bottom right inset: four-toed salamander nest with eggs. 


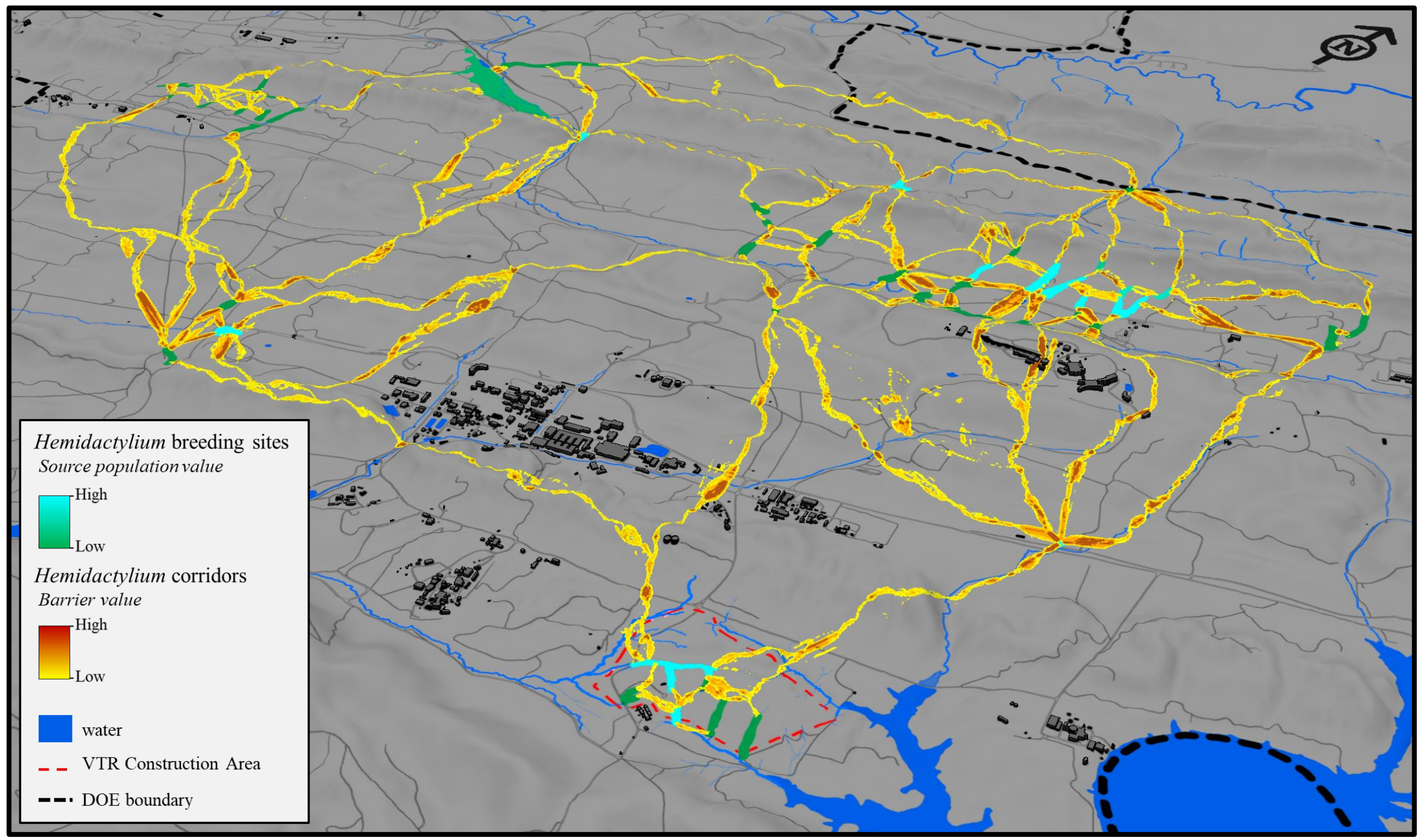

Figure 10. Four-toed salamander (Hemidactylium scutatum) core populations (brighter cores indicate larger population size) and dispersal corridors (darker reds indicate presence of barriers) on the ORR as modeled with the Circuitscape toolkit (McRae et al. 2013) with a compositive cost surface (vegetation height, soil saturation, infrastructure, and landscape "ruggedness") at <1-m raster cell resolution (adapted from Wade and Carter, 2020). 

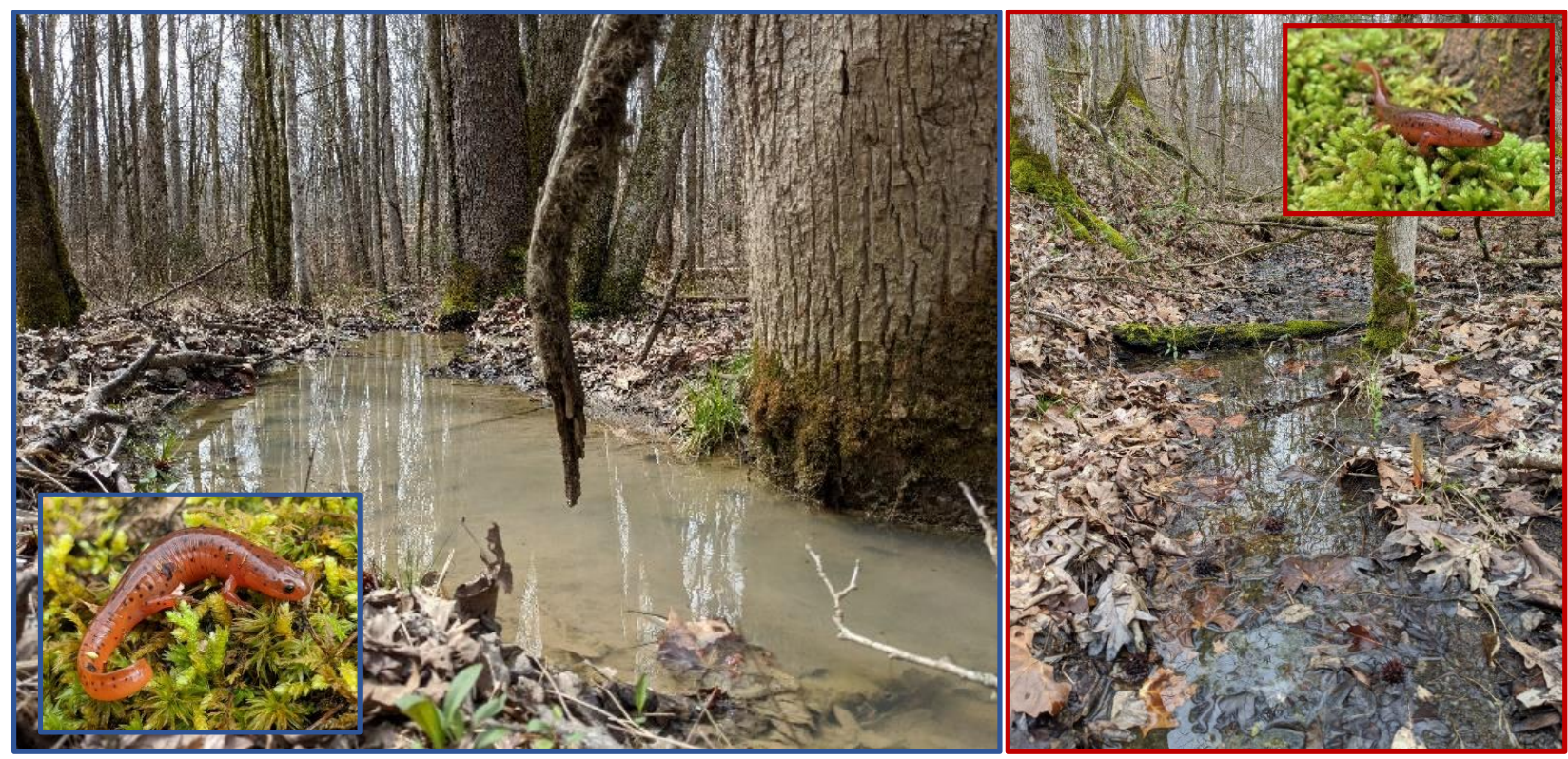

Figure 11. Left: Recently metamorphosed mud salamander (Pseudotriton montanus) observed on 13 March 2020 in a seep associated with Melton Brach and wetland MBNT1-5 in the VTR operations area. Right:

Second metamorph mud salamander observed on 30 March 2020 in a seep at the lower end of MBNT1-5 near where Melton Branch passes under the HPPR (Health Physics Research Reactor) Access Road. Mud salamanders have not been recorded outside of the VTR construction area, despite decades of aquatic sampling by the ORNL Environmental Sciences Division within other portions of the Melton Branch watershed. The two individuals pictured here represent the first and only mud salamanders verified within Roane County, Tennessee. Their associated wetlands fall within the comparatively less disturbed portion of Melton Branch watershed (see Figure 12).

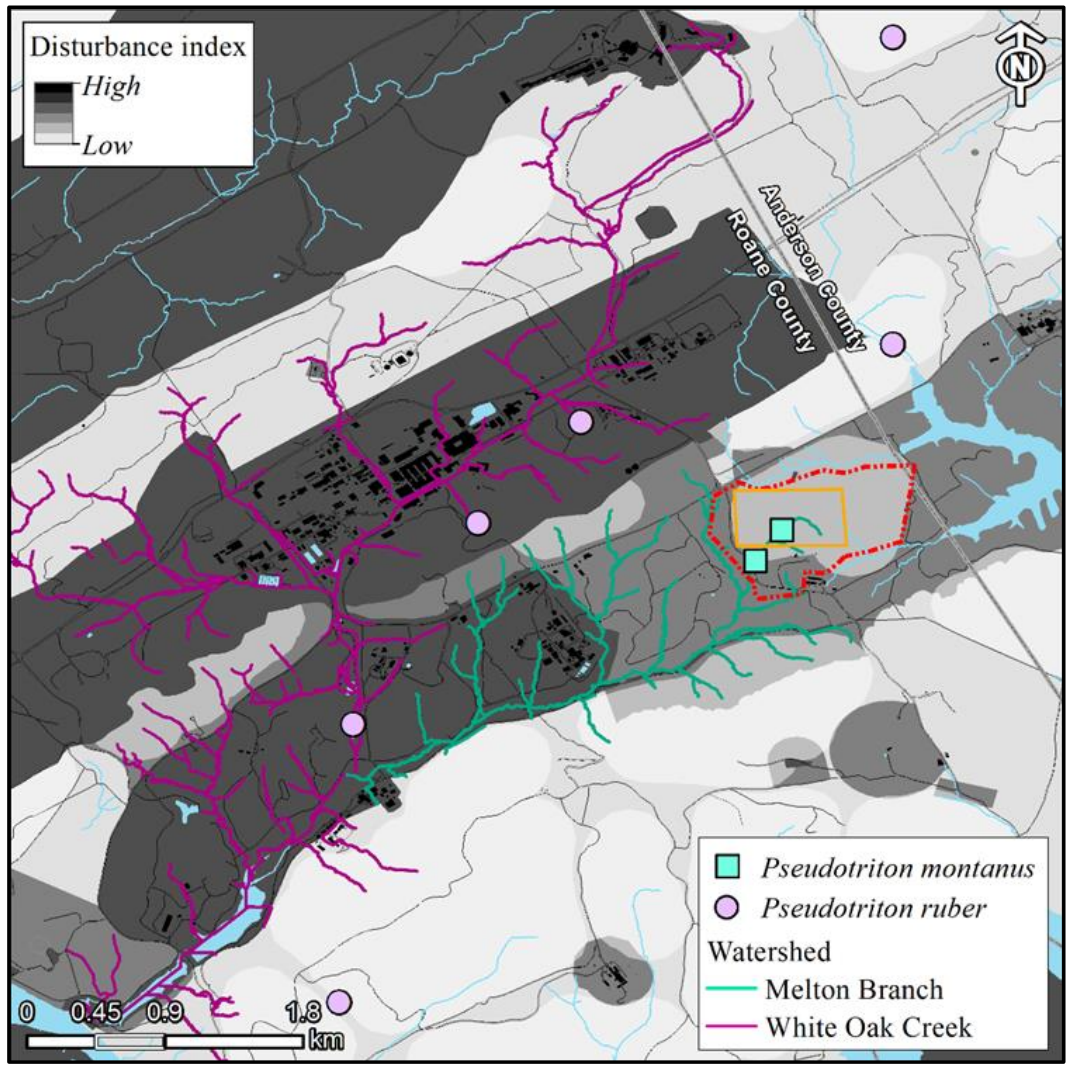

Figure 12. Distribution of Pseudotriton spp in the White Oak Creek and Melton Branch watershed based on targeted survey from 2019 to 2020. The mud salamander (Pseudotriton montanus) has been observed only in the smaller and comparatively less disturbed Melton Branch watershed, within the VTR construction area (red) and operations area (orange). Lighter areas indicate lower frequency and extent of human disturbance.

Disturbance index was defined as the scaled sum effect of development, contaminant presence, and frequency of forest thinning through time. 
Table 4. Wildlife observed during 2020 visual encounter and nighttime call surveys (anurans). Appendix II includes all contemporary and historical vertebrate fauna known from the VTR review area.

\begin{tabular}{|c|c|c|}
\hline Common name & Scientific name & Status \\
\hline \multicolumn{3}{|c|}{ Amphibians } \\
\hline \multicolumn{3}{|c|}{ Anurans (including calls) } \\
\hline American toad & Anaxyrus americanus & \\
\hline Cope's gray treefrog & Hyla chrysoscelis & \\
\hline Bullfrog & Lithobates catesbeianus & \\
\hline Green frog & Lithobates clamitans & \\
\hline Pickerel frog & Lithobates palustris & \\
\hline Southern leopard frog & Lithobates sphenocephalus & \\
\hline Spring peeper & Pseudacris crucifer & \\
\hline Upland chorus frog & Pseudacris feriarum & \\
\hline \multicolumn{3}{|c|}{ Caudates } \\
\hline Spotted salamander & Ambystoma maculatum & \\
\hline Dusky salamander & Desmognathus fuscus complex & \\
\hline Two-lined salamander & Eurycea bislineata complex & \\
\hline Four-toed salamander & Hemidactylium scutatum & $\mathrm{SD}, \mathrm{FS}$ \\
\hline Eastern newt & Notophthalmus viridescens & \\
\hline Slimy salamander & Plethodon glutinosis & \\
\hline Zigzag salamander & Plethodon ventralis & \\
\hline Mud salamander & Pseudotriton montanus & FS \\
\hline \multicolumn{3}{|c|}{ Mammals } \\
\hline \multicolumn{3}{|c|}{ Small mammals } \\
\hline Short-tailed shrew & Blarina brevicauda & \\
\hline Long-tailed weasel & Mustela frenata & \\
\hline White-footed mouse & Peromyscus leucopus & \\
\hline Peromyscus & Peromyscus spp & \\
\hline Eastern gray squirrel & Sciurus carolinensis & \\
\hline Cotton rat & Sigmodon hispidus & \\
\hline Eastern cottontail & Sylvilagus floridanus & \\
\hline Eastern chipmunk & Tamias striatus & \\
\hline \multicolumn{3}{|c|}{ Other (including sign) } \\
\hline Coyote & Canis latrans & \\
\hline Bobcat & Lynx rufus & \\
\hline Raccoon & Procyon lotor & \\
\hline Deer & Odocoileus virginianus & \\
\hline \multicolumn{3}{|c|}{ Reptiles } \\
\hline \multicolumn{3}{|c|}{ Squamates } \\
\hline Wormsnake & Carphophis amoenus & \\
\hline Racer & Coluber constrictor & \\
\hline Watersnake & Nerodia sipedon & \\
\hline Ratsnake & Pantherophis spiloides & \\
\hline Five-lined skink & Plestiodon fasciatus & \\
\hline
\end{tabular}


Table 4. Wildlife observed during 2020 visual encounter and nighttime call surveys (anurans) (continued). Appendix II includes all contemporary and historical vertebrate fauna known from the VTR review area.

\begin{tabular}{ll}
\hline \multicolumn{1}{c}{ Common name } & \multicolumn{1}{c}{ Scientific name } \\
\hline Gartersnake & Thamnophis sirtalis \\
Little brown skink & Scincella lateralis \\
Redbellied snake & Storeria occipitomaculata \\
Box turtle & Testudines \\
& Terrapene carolina \\
Cave isopods & Notable invertebrates \\
\hline
\end{tabular}

SD - State-listed In Need of Management

\subsubsection{Forest Inventory}

Current condition of the VTR footprint forest - The VTR construction area footprint occupies 150.4 acres (60.86 ha) in the Ramsey Drive and HPRR (Health Physics Research Reactor) Access Road area southeast of the main ORNL campus. The current condition of the VTR footprint forest can most easily be determined from a previous forest inventory undertaken in 2011 covering portions of Wildland Management Unit (Compartment) \#21, which lies near the southcentral portion of the ORR. Fieldwork for the inventory was conducted from 9-15 September 2011. Sampling points were established on a 300 by $300 \mathrm{ft}$ grid. A subset of 66 sampling points that fell within the review area was extracted from the original inventory data set to prepare the following analysis (Figure 13).

The following analysis describes the forest on a 135.1-acre (54.67-ha) portion of the footprint east of HPRR Access Road. Although no recent inventory can be used to describe the remaining 15.3 acres (6.19 ha) of the footprint west of HPRR Access Road, general observations and records maintained the ORNL Forester indicate that the area is slightly more mature forest than east of HPRR Access Road. Unlike the area east of HPRR Access Road, much of this forest was not subject to pine salvage during the 1965 to 1966 southern pine beetle outbreak. The area also was used as an ORNL Ecology Field Area during the 1960s and 1970s.

Land use-Spatial distribution of land use categories in the proposed VTR review area corresponding to habitat types are shown in Figure 14. The uses include forest, right-of-way, and developed areas. Forest comprises approximately $94.6 \%$ (127.9 acres) of the area, right-of-way comprises $3.0 \%$ (4.0 acres), developed areas occupy $1.9 \%$ (2.5 acres), and early successional vegetation occurs on $0.5 \%$ (0.6 acres). Sections 3.1.1-3.1.4 provide details of finer-scale forest plant community and water resources.

Basal area - The total basal area of the VTR forest in 2011 was $17,686 \mathrm{ft}^{2}$ with standing dead trees accounting for approximately 5.6\%. However, because of the loss ash trees caused by a subsequent Emerald Ash Borer infestation, this figure may approach $10.6 \%$ by now. Basal area per acre for live trees averaged $123 \mathrm{ft}^{2}$ per acre.

A list of species and live tree basal area statistics for the study area are provided in Table A3.1 (Appendix III). Thirty-five species were identified. Trees with a diameter at breast height ( $\mathrm{dbh}, 4.5 \mathrm{ft}) \geq 10.0 \mathrm{in}$. accounted for $61.0 \%$ of the total basal area. Among trees $\geq 10.0$ in. dbh, 6 species contributed $>5 \%$ of forest basal area, including white oak (21\%), tulip poplar (13\%), Virginia pine (13\%), sweetgum (9\%), northern red oak (8\%), and red maple (7\%). Among sapling-size trees ( $\mathrm{dbh} \geq 2$ in. and $<10 \mathrm{in}$.), species ranking based on basal area representing $>5 \%$ included 8 species: red maple (14\%), sweetgum (14\%), 
white oak (9\%), ash (7\%), mockernut hickory (6\%), sourwood (6\%), Virginia pine $(6 \%)$, and eastern redcedar $(5 \%)$.

At the genus level, oaks in the review area accounted for $38 \%$ of the live basal area of trees $\geq 10 \mathrm{in}$. dbh (Table A3.2) but provided only 11\% of the sapling-size class basal area (a typical symptom of mature oak forests in the absence of fire and canopy disturbances, and also increased herbivory. Under these conditions, oak faces an eventual diminishment within the stand). White oaks (including white, post, and chinkapin oaks) provided $21 \%$ of the live basal area of trees $\geq 10$ in. dbh but only represented $9 \%$ of the sapling-size class basal area. Red oaks (including northern red, southern red, scarlet, and black oaks) provided $17 \%$ of the live basal area of trees $\geq 10$ in. dbh but only represented $2 \%$ of the sapling-size class basal area. Pines accounted for $17 \%$ of the live basal area of trees $\geq 10 \mathrm{in}$. dbh and $9 \%$ of the total basal area for trees $<10 \mathrm{in}$. dbh. Maples accounted for $8 \%$ of the live basal area of trees $\geq 10 \mathrm{in}$. dbh and $19 \%$ of the live basal area of trees $<10 \mathrm{in}$. dbh. Hickories accounted for $5 \%$ of trees $\geq 10 \mathrm{in}$. dbh and $6 \%$ of the saplings.

Tree number and density - The number of live trees and saplings in the VTR review area forest in 2011 totaled 64,178, averaging 475 stems per acre of trees $>2$ in. dbh (Table A3.3). There were 68.2 trees $>10$ in. dbh per acre on average across all forested sample points in the area, totaling 9,214 trees. There was an average of 406.8 sapling trees ( $<10 \mathrm{in}$. $\mathrm{dbh}$ ) per acre in this forest, totaling 54,964 saplings. For trees $\geq 10$ in. dbh, white oak (12.5) provided the greatest average number of stems per acre, followed by Virginia pine (10.8), sweetgum (7.7), yellow poplar (7.2), and red maple (5.8). Among sapling-size trees, species ranking for the average number of stems per acre included sweetgum (78.8), red maple (46.9), dogwood (39.8), black gum (27.6), and sourwood (27.3).

Volume of merchantable timber-The volume of merchantable timber in the VTR footprint in 2011 totaled 750,319 board $\mathrm{ft}$ (bf, international $1 / 4$ in. rule), averaging 5,554 bf per acre (Table A3.4). White oak (174,201 bf), yellow poplar (152,698 bf), Virginia pine (97,584 bf), and sweetgum (80,285 bf) collectively contributed $67 \%$ of the merchantable timber in this area. Species rank for number of merchantable stems (Table A3.3) included white oak (1260), Virginia pine (1063), yellow poplar (906), sweetgum (875), and shortleaf pine (334). At the genus level, oaks collectively with yellow poplar accounted for $60 \%$ of the marketable timber in the area (Table A3.5). To estimate the current volume of marketable timber, the volumes determined from the 2011 inventory may be adjusted by compounding over the 8 intervening growing seasons. A modest annual volume growth rate of $3 \%$ was assumed and applied to reflect an estimate of present stand volume. For example, the total volume at the time of this report would approach 930,304 bf, or 6,886 bf per acre. Ash volumes were excluded from the compounding due to near complete tree mortality following emerald ash borer infestations following the original inventory.

Large-diameter trees - Table A3.6 provides a list of the largest-diameter trees of selected species and a count of all tally trees $>30 \mathrm{in}$. dbh, measured at sample points in the area. Only 2 trees were tallied with a $\mathrm{dbh}>30 \mathrm{in}$. in the study area; both were oaks, and each measured at $30.5 \mathrm{in}$. One, a southern red oak, is located near the center of the proposed VTR operations area.

Additional observations-Because of the effect of the introduction of an invasive exotic insect (the emerald ash borer), ash (Fraxinus spp) on the site, originally representing approximately 5\% of live basal area and $2.1 \%$ of the merchantable volume, may now be considered absent from the live component of the current VTR forest.

No chestnut oak was recorded in the inventory, but there was an abundance of white oak and sweetgum; this would be expected given the low elevations ( $<950 \mathrm{ft}$ ). 


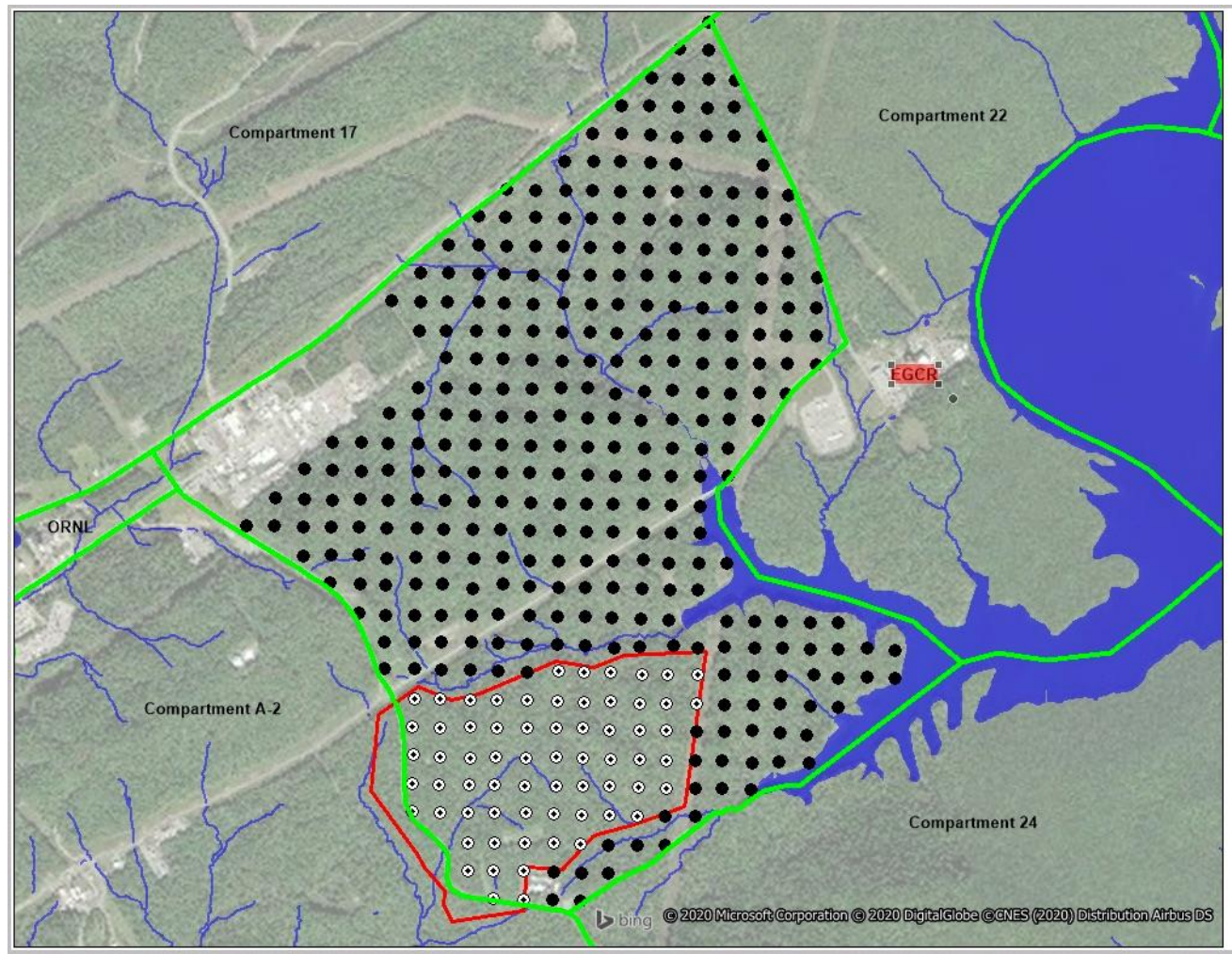

Figure 13. 2011 forest inventory map for the proposed VTR site and vicinity.

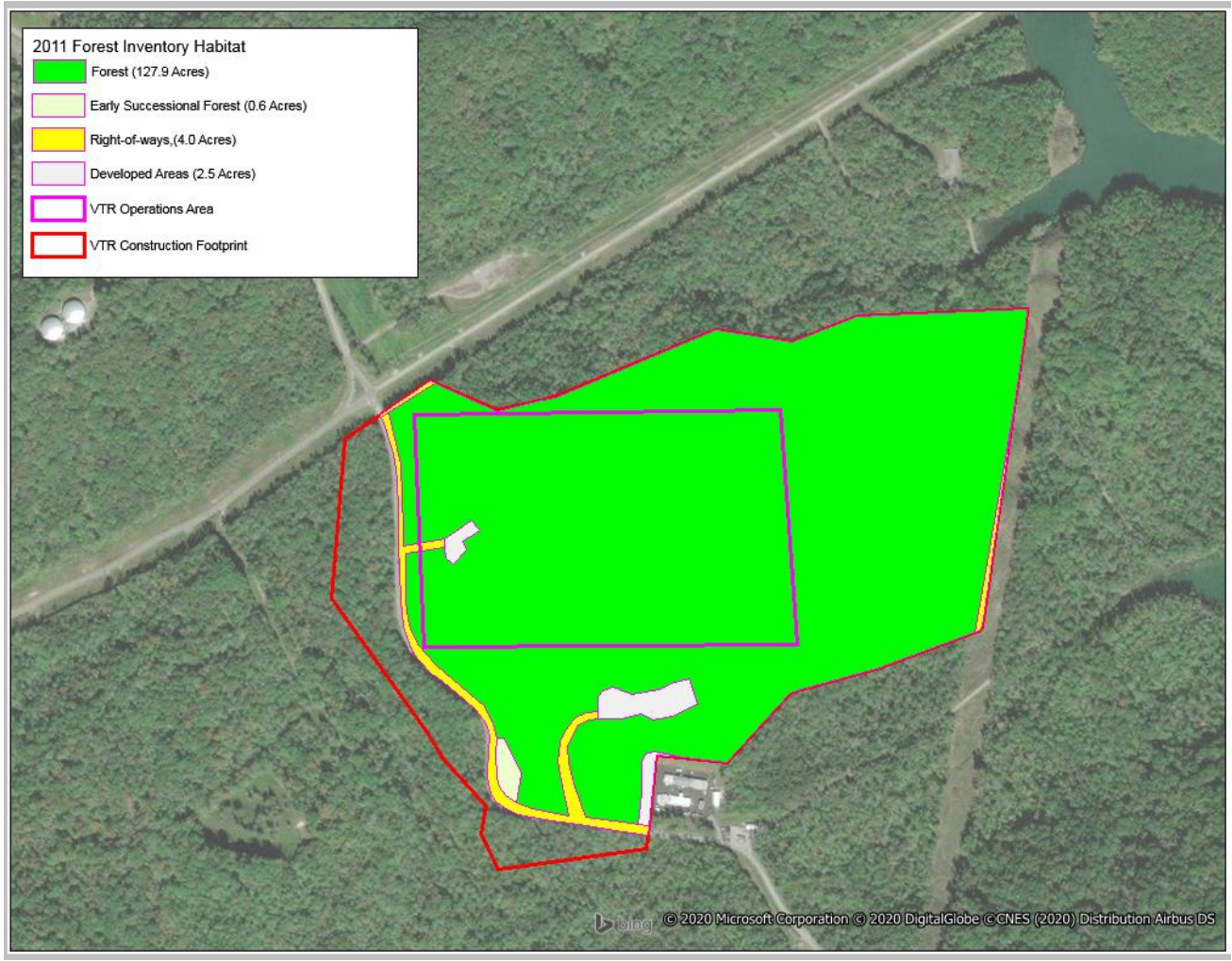

Figure 14. Spatial distribution of land use types for the proposed VTR site. 


\section{TIMBER CLEARING AND DISPOSAL}

Timber clearing-Timber is a realty asset and must therefore be properly disposed. DOE currently has a timber sale agreement in place with a local wood-using business, Oak Ridge Hardwoods, LLC (RETimber-03-0001). This contractor has the option to harvest or otherwise recover merchantable wood from project sites, and in return agrees to remit to DOE an established stumpage (price per unit of wood removed). The designated reservation forester facilitates this operation on behalf of DOE to ensure agreement terms and state logging regulations are followed. There would be no cost to the project for these actions. Furthermore, a project may experience a significant cost abatement as the volume of the site vegetation to be disposed is greatly reduced.

The contractor should be allowed to examine the site as soon as possible prior to VTR construction area footprint clearing to verify timber quality, volume estimates, and access requirements and should be made aware of project startup dates and deadlines to arrange a qualified logging crew to perform the harvest. The duration of logging operations varies with site size, terrain and access limitations, and seasonal weather and may be further constrained by timing considerations to protect endangered species or by administrative delays caused by competing site security or utility operations. Ideally, for a project of this size, a planning allowance of at least 12 months in advance of construction startup should be adequate for the logging period and potential delays.

Residual vegetation woody and debris would remain following the harvest, and the land use would still be considered "forestland." The VTR project would be responsible for taking the defining steps converting the harvested forestland to "developed" land use classification by initiating activities that are more purely "clearing" (e.g., removal of all vegetation, leaf litter, stumps, soil grading). The DOE timber sale agreement does not include any requirement for performance of land clearing; state forestry best management practices would apply to the site until development is initiated.

Logging access/egress - The VTR site is easily accessible from the HPRR Access Road from two existing points that avoid wetland crossings. Wood taken from the site would likely be sent in two directions depending on markets used; the following describes routes least impactful for ORNL operations.

For wood taken to Oak Ridge and other points to the northeast, the recommended routing would be northward along the HPRR Access Road, then northeastward along Ramsey Drive to the EGCR (Experimental Gas Cooled Reactor) Access Road, then northward to Bethel Valley Road, northeastward through the ORNL East Portal to Scarboro Road; transporting vehicles exit the ORR either by turning northward onto Scarboro Road to SR 62 or by continuing northeastward as Bethel Valley Road becomes SR 170 (under various names) to US $25 \mathrm{~W}$ or 1-75.

For wood taken toward Kingston and pointed west, the recommended routing would be northward along the HPRR Access Road, then southwest along Melton Valley Drive to First Street, northward to Bethel Valley Road, and then southwestward to SR 95. Traveling northward on SR 95 and then westward at SR 58 allows wood to be taken to a chipping facility at the East Tennessee Technology Park on the ORR or onward to I-40.

Disposal of residual vegetation-The preferred method for disposing of remaining vegetation is grinding/mulching. The mulched material may be repurposed as erosion control cover and berms, although depths may be recommended to promote biotic recovery and discourage leachates entering nearby waterways. Nearby reservation sites should be identified beforehand that could accommodate staging of any surplus mulch. To limit the effect of complete vegetation removal, this can be performed 
piecemeal, depending on the pace of the site grade work, although care must be taken to avoid leaving inaccessible pockets of debris that would increase residual wildfire fuel loads.

Alternatively, woody debris may be burned in place with trench, pile, or windrow burning. Per the DOE ORR Wildland Fire Management Plan, all open burning on the ORR requires review and authorization by the federal reservation manager, the appropriate site office, and the reservation forester; prerequisite burn plan development, review, and authorization can typically require 6-8 weeks to complete.

Given the size of the proposed clearing, the amount of residual debris would likely overwhelm the capacity of the nearby Hawk's Nest Woody Debris Disposal Facility and so this option is not recommended.

Because of wildfire risk, under no circumstances should woody debris be left on site.

Wildland fire planning - Construction of the VTR at the proposed location will create an additional wildland interface of site operations with the ORR's wildfire fuels, requiring the application of current, applicable National Fire Protection Association Standards (1141, 1143, and 1144). The proposed VTR site lies within portions of two fire management units, \#20 Melton Valley and \#21 Ramsey, and construction would require modification to the corresponding existing wildland fire pre-plans. The site is also currently within the ORNL emergency response zone; response times to and through the area following project completion should remain unchanged. Fuel beds may need to be modified (clearing and maintaining setbacks, reducing residual fuel loads presented by dead and dense vegetation or logging slash) to ensure safe conditions remain post-construction.

\section{CONCLUSIONS AND CULTURAL CONSIDERATIONS}

This report includes a compilation of new and existing data regarding aquatic resources, sensitive flora and fauna, forest condition, and cultural and historical resources that might be impacted if the proposed VTR project proceeds at the Oak Ridge site. Table 5 outlines effects that have the potential to be deemed significant impacts, alongside social and cultural considerations. This assessment is limited to resources that are known contemporary components of the VTR review area. Appendix I provides additional resources that were identified during pre-survey screening, and Appendix II identifies all vertebrate wildlife known from the VTR review area.

In total, 151 vertebrate wildlife and at least 1 notable invertebrate are known from the review area (Appendix II). We observed few rare plant species during spring and summer 2020, but additional survey is required to confirm presence of state- and/or federally listed orchids (Platanthera integrilabia and $P$. flava var. herbiola). Of all the species known from the VTR construction area, at least 10 are afforded special legal protection under state or federal law, 5 species are considered to be both BCCs and BMCs, 3 species are BCC-only, and 2 species are BMC-only (in addition to $\geq 98$ bird species afforded protection under MBTA 16 U.S.C. $\S \S 703-711)$. Additionally, at least 1 species is considered rare by TDEC, and 10 species represent ORNL FS for management and/or research (Appendix II).

Impacts to FS and the Melton Branch ARA would represent impacts to long-term research and monitoring programs that involve ORNL, TDEC, DOE, and many of their government and university partners (Baranski 2009, 2011, Carter et al. 2020). Moreover, considerable effort is placed into development of management plans for FS (e.g., Giffen et al. 2012; Roy et al. 2014; McCracken et al. 2015; Par et al. 2015; McCracken et al. 2017; Carter et al. 2020), and loss of diversity or natural area on the ORR, and Oak Ridge National Environmental Research Park represents additional potential impacts to research and science education. 
Considering other longer-term surveys elsewhere on the ORR (e.g., DeRolph et al. 2019a; Carter et al. 2019), the VTR construction area contains above average quantity and quality of natural and culturally important resources (Baranski 2009, 2011). The highest richness and diversity within the site appear to be associated with wetland MBTN1-5, the seeps that feed it, and stream riparian along Melton Branch (Melton Branch ARA). Unidentified (potentially state- and/or federally listed) Platanthera spp, statelisted in-need-of-management four-toed salamanders (Hemidactylium scutatum, a FS for both research and management on the ORR), and a second FS, the mud salamander (Pseudotriton montanus), were each observed within wetland MBTN1-5. Nevertheless, sensitive and focal resources are present in all wetlands in the VTR construction area, and higher apparent diversity in MBTN1-5 might reflect the relatively greater amount of search effort that it received. For instance, four-toed salamanders were not detected in MBTN1-5 until the third survey, in which 5 nests were located within $10 \mathrm{~m}$ of young Platanthera spp. In contrast, additional wetlands within the Bearden Creek watershed portion of the VTR construction area (Figure 5) were surveyed for the first time in June 2020, yet several individuals were located along wetland BDWT1d-1 during a single survey. Given habitat characteristics, we expect that state-listed $H$. scutatum occurs in wetlands and moist forest throughout the VTR review area. Under either scenario, presence either Platanthera species, wetlands within the review area comprise a significant number of all known demes for this sensitive FS on the ORR (Figure 10).

The combination of Platanthera spp, H. scutatum, and Pseudotriton on the ORR is indicative of acidic seep wetlands connected by complex ephemeral drainages, often with losing reaches along first-order streams (Chester et al. 2015; Baranski 2009, 2011; Carter et al. 2020). The only other wetland-stream complex on the ORR in which Platanthera flava var. herbiola, H. scutatum, and Pseudotriton (albeit a separate species, $P$. ruber) each occur is in a portion of Bear Creek Valley that is also under strong consideration for development. Indeed, many of the associated wetlands in Bear Creek Valley were already lost or hydrologically compromised during development of the Environmental Management Waste Management Facility and the extension of the UPF Haul Road (Peterson et al. 2005). Additional adjacent wetlands were compromised by construction of access roads during site characterization for the planned On-Site Waste Disposal Facility (OSWDF). These and nearly all other wetlands with the described species composition - or characteristics to support them - are found within the footprint of the proposed OSWDF (DeRolph et al. 2019a, 2019b). Overall, the area proposed for the OSWDF represents a higher-value natural area by nearly all definitions (Peterson et al. 2018, DeRolph et al. 2019b), but additive effects from these current land use plans deem the VTR review area to be of exceptional natural and cultural value. 
Table 5. Overview of potential impacts on known resources to result from development of the VTR and associated infrastructure. Impacts stated here represent the opinion of the ORNL Natural Resources Program only. In providing this opinion, the ORNL Natural Resources Program considered federal and state listing status, current state of the given resource(s) elsewhere on the ORR, concurrent or imminent loss of habitat from additional projects, and additive, cumulative, and long-term effects of the VTR project. Additional sensitive resources identified during pre-survey analysis but concluded to be absent or unlikely within the VTR review area are outlined in Appendix I.

\begin{tabular}{|c|c|c|c|}
\hline Resource & Summary & Natural resource value & $\begin{array}{l}\text { Additional considerations: social/cultural value and } \\
\text { anticipated level of impact }\end{array}$ \\
\hline $\begin{array}{l}\text { - Gray bat (Myotis } \\
\text { grisescens) }\end{array}$ & $\begin{array}{l}\text { - Gray bats were detected within or } \\
\text { adjacent to the VTR construction } \\
\text { area at relatively high frequency } \\
\text { - Caves within } 1 \text { mile of VTR } \\
\text { construction area contain gray bats }\end{array}$ & $\begin{array}{l}\text { - Federal- and state-listed } \\
\text { Endangered species }\end{array}$ & $\begin{array}{l}\text { - Impact to federal- and state-listed species or habitat } \\
\text { - Impacts to gray bats would result primarily from loss of } \\
\text { foraging habitat } \\
\text { - Additional surveys within the VTR operations area are needed } \\
\text { - Winter and early- to mid-summer surveys of caves adjacent to } \\
\text { VTR are needed } \\
\text { - Impact likely less than significant } \\
\text { - Additive effects might be significant }\end{array}$ \\
\hline $\begin{array}{l}\text { - Northern long- } \\
\text { eared bat (Myotis } \\
\text { septentrionalis) }\end{array}$ & $\begin{array}{l}\text { - Northern long-eared bats were } \\
\text { detected at extremely low } \\
\text { frequency within the VTR } \\
\text { construction area } \\
\text { - Caves within } 1 \text { mile of VTR } \\
\text { construction area contain northern } \\
\text { long-eared bats }\end{array}$ & $\begin{array}{l}\text { - Federal- and state-listed } \\
\text { Threatened species }\end{array}$ & $\begin{array}{l}\text { - Impact to federal and state-listed species or habitat } \\
\text { - Impacts to northern long-eared bats would result from loss of } \\
\text { foraging and maternity roost habitat } \\
\text { - Despite low detection frequency within the VTR construction } \\
\text { area, preliminary surveys did not occur within much of the } \\
\text { forest interior } \\
\text { - Additional surveys are needed within the VTR operations area } \\
\text { to detect potential summer roosts } \\
\text { - Winter hibernaculum surveys of caves adjacent to VTR are } \\
\text { needed per USFWS } \\
\text { - Impact likely less than significant } \\
\text { - Additive effects might be significant }\end{array}$ \\
\hline $\begin{array}{l}\text { - Indiana bat } \\
\text { (Myotis sodalis) }\end{array}$ & $\begin{array}{l}\text { - Indiana bats were detected at } \\
\text { extremely low frequency within } \\
\text { the VTR construction area } \\
\text { - Caves within } 1 \text { mile of VTR } \\
\text { construction area contain Indiana } \\
\text { bats }\end{array}$ & $\begin{array}{l}\text { - Federal- and state-listed } \\
\text { Endangered species }\end{array}$ & $\begin{array}{l}\text { - Impact to federal and state-listed species or habitat } \\
\text { - Impacts to Indiana bats would result from loss of foraging and } \\
\text { maternity roost habitat } \\
\text { - Despite low detection frequency within the VTR construction } \\
\text { area, preliminary surveys did not occur within much of the } \\
\text { forest interior } \\
\text { - Additional surveys are needed within the VTR operations area } \\
\text { to detect potential summer roosts } \\
\text { - Winter hibernaculum surveys of caves adjacent to VTR are } \\
\text { needed per USFWS } \\
\text { - Impact likely less than significant } \\
\text { - Additive effects might be significant }\end{array}$ \\
\hline
\end{tabular}


Table 5. Overview of potential impacts on known resources to result from development of the VTR and associated infrastructure (continued). Impacts stated here represent the opinion of the ORNL Natural Resources Program only. In providing this opinion, the ORNL Natural Resources Program considered federal and state listing status, current state of the given resource(s) elsewhere on the ORR, concurrent or imminent loss of habitat from additional projects, and additive, cumulative, and long-term effects of the VTR project. Additional sensitive resources identified during pre-survey analysis but concluded to be absent or unlikely within the VTR review area are outlined in Appendix I.

\begin{tabular}{|c|c|c|c|}
\hline Resource & Summary & Natural resource value & $\begin{array}{c}\text { Additional considerations: social/cultural value and } \\
\text { anticipated level of impact }\end{array}$ \\
\hline $\begin{array}{l}\text { - Little brown bat } \\
\text { (Myotis } \\
\text { lucifugus) }\end{array}$ & $\begin{array}{l}\text { - Little brown bats were detected at } \\
\text { relatively high frequency within } \\
\text { the VTR construction area }\end{array}$ & - State-listed Threatened & $\begin{array}{l}\text { - Impact to state-listed species or habitat } \\
\text { - Currently under review for ESA listing } \\
\text { - Impact likely less than significant } \\
\text { - Additive effects might be significant }\end{array}$ \\
\hline $\begin{array}{l}\text { - Tricolored bat } \\
\text { (Perimyotis } \\
\text { subflavus) }\end{array}$ & $\begin{array}{l}\text { - Tricolored bats were detected at } \\
\text { relatively high frequency within } \\
\text { the VTR construction area }\end{array}$ & - State-listed Threatened & $\begin{array}{l}\text { - Impact to state-listed species or habitat } \\
\text { - Currently under review for ESA listing } \\
\text { - Impact likely less than significant } \\
\text { - Additive effects might be significant }\end{array}$ \\
\hline $\begin{array}{l}\text { - Small-footed bat } \\
\text { (Myotis leibii) }\end{array}$ & $\begin{array}{l}\text { - Small-footed bats were detected at } \\
\text { relatively low frequency in the } \\
\text { VTR construction area }\end{array}$ & $\begin{array}{l}\text { - State-listed In Need of } \\
\text { Management }\end{array}$ & $\begin{array}{l}\text { - Impact to state-listed species or habitat } \\
\text { - Habitat within the VTR construction area is less than ideal for } \\
\text { small-footed bats } \\
\text { - Impact likely not significant } \\
\text { - Additive effects might be significant }\end{array}$ \\
\hline $\begin{array}{l}\text { - Migratory birds } \\
\text { - } \text { BCCs } \\
\text { - BMCs }\end{array}$ & $\begin{array}{l}\text { - } 98 \text { species of migratory birds have } \\
\text { been recorded within the VTR } \\
\text { construction area, including birds } \\
\text { detected during adjacent Partners } \\
\text { in Flight surveys } \\
\text { - } 2020 \text { field surveys confirmed } \\
\text { current occupancy of the VTR } \\
\text { construction area by } 48 \text { migratory } \\
\text { bird species } \\
\text { - } 6 \text { bird species that are considered } \\
\text { as both BCCs and BMCs occur } \\
\text { within the VTR construction area } \\
\text { - } 2 \text { additional species are BCC-only } \\
\text { - } 2 \text { additional species are BMC-only }\end{array}$ & $\begin{array}{l}\text { - MBTA } \\
\text { - USFWS focal species } \\
-2 \text { BCC taxa } \\
\text { - } 2 \text { BMC taxa } \\
\text { - } 6 \text { BCC + BMC taxa } \\
\text { - FS }\end{array}$ & $\begin{array}{l}\text { - By definition of "migratory bird," timing of survey insufficient } \\
\text { to provide the full extent of occupancy of the VTR construction } \\
\text { area by migratory species } \\
\text { - Observable impacts to overall ORR populations require } \\
\text { additional surveys and analyses } \\
\text { - Impacts to migratory birds from VTR alone are likely less than } \\
\text { significant } \\
\text { - If one considers additional impending development on the } \\
\text { ORR, additive effects highly likely to be significant }\end{array}$ \\
\hline $\begin{array}{l}\text { - Bald eagle } \\
\text { (Haliaeetus } \\
\text { leucocephalus) }\end{array}$ & $\begin{array}{l}\text { - Bald eagle breeding pairs have } \\
\text { been noted in recent years within } \\
\text { the VTR construction area }\end{array}$ & $\begin{array}{l}\text { - Bald and Golden Eagle } \\
\text { Protection Act }\end{array}$ & $\begin{array}{l}\text { - Impact to federal and state-listed species or habitat } \\
\text { - Habitat within VTR less than ideal for bald eagles }\end{array}$ \\
\hline
\end{tabular}


Table 5. Overview of potential impacts on known resources to result from development of the VTR and associated infrastructure (continued). Impacts stated here represent the opinion of the ORNL Natural Resources Program only. In providing this opinion, the ORNL Natural Resources Program considered federal and state listing status, current state of the given resource(s) elsewhere on the ORR, concurrent or imminent loss of habitat from additional projects, and additive, cumulative, and long-term effects of the VTR project. Additional sensitive resources identified during pre-survey analysis but concluded to be absent or unlikely within the VTR review area are outlined in Appendix I.

\begin{tabular}{|c|c|c|c|}
\hline Resource & Summary & Natural resource value & $\begin{array}{l}\text { Additional considerations: social/cultural value and } \\
\text { anticipated level of impact }\end{array}$ \\
\hline & & $\begin{array}{l}\text { - State-listed In Need of } \\
\text { Management } \\
\text { - BCC } \\
\text { - BMC } \\
\text { - FS }\end{array}$ & $\begin{array}{l}\text { - Impacts likely less than significant on local bald eagle } \\
\text { populations } \\
\text { - Additive effects likely less than significant }\end{array}$ \\
\hline $\begin{array}{l}\text { - Wood thrush } \\
\text { (Hylocichla } \\
\text { mustelina })\end{array}$ & $\begin{array}{l}\text { - Wood thrush breeding pairs were } \\
\text { observed within the VTR } \\
\text { construction area }\end{array}$ & $\begin{array}{l}\text { - State-listed In Need of } \\
\text { Management } \\
\text { - USFWS focal species } \\
\text { - } \text { BCC } \\
\text { - } \text { BMC } \\
\text { - FS }\end{array}$ & $\begin{array}{l}\text { - Impact to state-listed species or habitat } \\
\text { - Impact to NERP diversity / research opportunities } \\
\text { - Impact to ongoing management effort } \\
\text { - Impact not quantifiable without additional surveys } \\
\text { - Additive effects might be significant }\end{array}$ \\
\hline - Platanthera spp & $\begin{array}{l}\text { Platanthera spp sprouts were } \\
\text { observed in wetland MBNT1-5, } \\
\text { inside the VTR construction area, } \\
\text { but could not be positively } \\
\text { identified at this time because of } \\
\text { seasonal growth patterns } \\
\text { - Likely to be state-listed } \\
\text { Threatened } P \text {. flava var. herbiola, } \\
\text { but unable to rule out presence of } \\
\text { federally listed, Threatened, } P \text {. } \\
\text { integrilabia } \text { without additional } \\
\text { monitoring }\end{array}$ & $\begin{array}{l}\text { - Federal- and/or state- } \\
\text { listed species } \\
\text { - Rare }(P . \text { flava var. } \\
\text { herbiola) and/or } \\
\text { otherwise unknown }(P \text {. } \\
\text { integrilabia }) \text { on the ORR } \\
\text { - Wetland indicator } \\
\text { - FS }\end{array}$ & $\begin{array}{l}\text { - Impact to federal- and/or state-listed species or habitat } \\
\text { - Impact to NERP diversity/research opportunities } \\
\text { - NERP and ORR historically recognized for its } P \text {. flava var. } \\
\text { herbiola populations } \\
\text { - Largest P. flava var. herbiola populations elsewhere on the } \\
\text { ORR are under imminent threat of development } \\
\text { - Impact highly likely to be significant } \\
\text { - Additive effects significant }\end{array}$ \\
\hline - Ginseng & - Panax quinquefolius & $\begin{array}{l}\text { - State-listed Of Special } \\
\text { Concern-Commercially } \\
\text { Exploited }\end{array}$ & $\begin{array}{l}\text { - Impact to state-listed species or habitat } \\
\text { - Impacts likely less than significant } \\
\text { - Additive effects might be significant }\end{array}$ \\
\hline $\begin{array}{l}\text { Four-toed } \\
\text { salamander } \\
\text { (Hemidactylium } \\
\text { scutatum) }\end{array}$ & $\begin{array}{l}\text { - Several four-toed salamander } \\
\text { adults and nests with eggs were } \\
\text { observed throughout the VTR } \\
\text { construction and operations area }\end{array}$ & $\begin{array}{l}\text { - State-listed In Need of } \\
\text { Management } \\
\text { - FS } \\
\text { - VTR populations } \\
\text { represent } ~ 33 \% \text { of }\end{array}$ & $\begin{array}{l}\text { - Impact to state-listed species or habitat } \\
\text { - Largest populations elsewhere on the ORR are under imminent } \\
\text { threat of development } \\
\text { - Impact to NERP diversity/research opportunities and ongoing } \\
\text { management effort }\end{array}$ \\
\hline
\end{tabular}


Table 5. Overview of potential impacts on known resources to result from development of the VTR and associated infrastructure (continued). Impacts stated here represent the opinion of the ORNL Natural Resources Program only. In providing this opinion, the ORNL Natural Resources Program considered federal and state listing status, current state of the given resource(s) elsewhere on the ORR, concurrent or imminent loss of habitat from additional projects, and additive, cumulative, and long-term effects of the VTR project. Additional sensitive resources identified during pre-survey analysis but concluded to be absent or unlikely within the VTR review area are outlined in Appendix I.

\begin{tabular}{|c|c|c|c|}
\hline Resource & Summary & Natural resource value & $\begin{array}{c}\text { Additional considerations: social/cultural value and } \\
\text { anticipated level of impact }\end{array}$ \\
\hline & & $\begin{array}{l}\text { Hemidactylium source } \\
\text { populations on the ORR } \\
\text { - Wetland indicator } \\
\text { - Contaminants indicator }\end{array}$ & $\begin{array}{l}\text { - Populations are subject to ongoing research in the ORNL } \\
\text { Environmental Sciences Division } \\
\text { - Impact would be significant } \\
\text { - Additive effects would be significant }\end{array}$ \\
\hline $\begin{array}{l}\text { - Mud salamander } \\
\text { (Pseudotriton } \\
\text { montanus) }\end{array}$ & $\begin{array}{l}\text { - Two recently metamorphosed mud } \\
\text { salamanders were observed in wet } \\
\text { MBTN1-5, inside the VTR } \\
\text { operations area }\end{array}$ & $\begin{array}{l}\text { - Wetland/stream indicator } \\
\text { - Contaminants indicator } \\
\text { - Exceedingly rare on ORR } \\
\text { - FS }\end{array}$ & $\begin{array}{l}\text { - Loss would represent } 100 \% \text { loss of known mud salamanders in } \\
\text { Anderson and Roane Counties, Tennessee } \\
\text { - Impact to NERP diversity/research opportunities and ongoing } \\
\text { management effort } \\
\text { - Populations are subject to ongoing research in the ORNL } \\
\text { Environmental Sciences Division } \\
\text { - Impact would be significant } \\
\text { - Additive effects would be significant }\end{array}$ \\
\hline - Wetlands & $\begin{array}{l}\text { - No less than } 8.1 \text { acres ( } 3.3 \text { ha) of } \\
\text { wetland occur within the VTR } \\
\text { construction area } \\
\text { - Additional wetland would require } \\
\text { delineation if the project proceeds }\end{array}$ & $\begin{array}{l}\text { - Aquatic resource } \\
\text { - Subject to all applicable } \\
\text { state and federal } \\
\text { regulation } \\
\text { - Provide habitat for FS, } \\
\text { state-listed species, and } \\
\text { possible federal-listed } \\
\text { species }\end{array}$ & $\begin{array}{l}\text { - Impact to an aquatic resource } \\
\text { - Wetlands are likely to be classified as ETWs } \\
\text { - In-kind mitigation likely not possible on ORR } \\
\text { - Impact to NERP diversity/research opportunities } \\
\text { - ORNL/TDEC ARA (Melton Branch ARA) } \\
\text { - ORNL Biological Monitoring and Abatement Program focal } \\
\text { watershed } \\
\text { - Habitat for only Pseudotriton montanus in Anderson County or } \\
\text { - Roane County, Tennessee } \\
\text { - Ampact would be significant } \\
\text { - Additive effects would be significant }\end{array}$ \\
\hline - Streams & $\begin{array}{l}\text { - } 1,490 \mathrm{ft} \text { of mapped stream and } \\
\text { extensive WWCs within the VTR } \\
\text { construction area will require } \\
\text { additional hydrological } \\
\text { determination }\end{array}$ & $\begin{array}{l}\text { - Aquatic resource } \\
\text { - Subject to all applicable } \\
\text { state and federal } \\
\text { regulation } \\
\text { - Provide habitat for FS, } \\
\text { state-listed species, and } \\
\text { possible federal-listed } \\
\text { species }\end{array}$ & $\begin{array}{l}\text { - Impact to an aquatic resource } \\
\text { - Impact to NERP diversity/research opportunities } \\
\text { - ORNL/TDEC ARA (Melton Branch ARA) } \\
\text { - ORNL Biological Monitoring and Abatement Program focal } \\
\text { watershed } \\
\text { - Habitat for only Pseudotriton montanus in Anderson County or } \\
\text { Roane County, Tennessee } \\
\text { - Impact would be significant }\end{array}$ \\
\hline
\end{tabular}


Table 5. Overview of potential impacts on known resources to result from development of the VTR and associated infrastructure (continued). Impacts stated here represent the opinion of the ORNL Natural Resources Program only. In providing this opinion, the ORNL Natural Resources Program considered federal and state listing status, current state of the given resource(s) elsewhere on the ORR, concurrent or imminent loss of habitat from additional projects, and additive, cumulative, and long-term effects of the VTR project. Additional sensitive resources identified during pre-survey analysis but concluded to be absent or unlikely within the VTR review area are outlined in Appendix I.

\begin{tabular}{|c|c|c|c|}
\hline Resource & Summary & Natural resource value & $\begin{array}{c}\text { Additional considerations: social/cultural value and } \\
\text { anticipated level of impact }\end{array}$ \\
\hline - Seeps/springs & $\begin{array}{l}\text { - } \geq 30 \text { seeps and active springs occur } \\
\text { within the VTR construction area }\end{array}$ & $\begin{array}{l}\text { - Aquatic resource } \\
\text { Subject to all applicable } \\
\text { state and federal } \\
\text { regulation } \\
\text { Provide habitat for FS, } \\
\text { state-listed species, and } \\
\text { possible federal-listed } \\
\text { species }\end{array}$ & $\begin{array}{l}\text { - Additive effects would be significant } \\
\text { - Impact to an aquatic resource } \\
\text { - Impact to NERP diversity/research opportunities } \\
\text { - Habitat for only Pseudotriton montanus in Anderson County or } \\
\text { Roane County, Tennessee } \\
\text { - Impact would be significant } \\
\text { - Additive effects would be significant }\end{array}$ \\
\hline $\begin{array}{l}\text { - Hemlock } \\
\text { treatment area }\end{array}$ & $\begin{array}{l}\text { - } 37 \text { treated hemlocks occur within } \\
\text { the VTR operations area }\end{array}$ & $\begin{array}{l}\text { - FS } \\
\text { - Vulnerable in } \\
\text { Southeastern United } \\
\text { States owing to hemlock } \\
\text { woolly adelgid }\end{array}$ & $\begin{array}{l}\text { - Hemlocks within the VTR operations area are among the } \\
\text { largest-diameter hemlocks on the ORR } \\
\text { - Impact to NERP diversity, research opportunities, and ongoing } \\
\text { management effort } \\
\text { - Additive effects might be significant }\end{array}$ \\
\hline
\end{tabular}

Mitigation-Mitigation is anticipated if the VTR project proceeds as proposed at the Oak Ridge site. We cannot provide recommendations for mitigation options without additional assessment. However, our current results and ongoing assessment of the ORR's resources suggest that inkind mitigation (i.e., protection or enhancement of ecologically similar resources) could entail greater acreage than might be available elsewhere on the ORR. Acceptable mitigation measures for many resources - notably, aquatic features (under Tennessee regulations) and federally listed bats - depend on the quality and type of habitat (e.g., foraging, roosting, hibernacula). Thus, additional surveys may be required by USFWS and TDEC to adequately assess the extent and nature of occupancy by status species. Minimally, these should include targeted surveys for federally listed bats from early summer to late winter, additional monitoring of unidentified Platanthera spp through late summer, and additional assessment of ETWs via TRAM. Thus, avoidance of sensitive resources during construction and operations activities is the preferred first approach. If avoidance is not possible, at least informal consultation between DOE, USFWS, and TDEC should be initiated immediately. Owing to agreements between DOE, TDEC, and TWRA (Giffen et al. 2012; Carter et al. 2020), TDEC and TWRA must also be notified and/or engaged in consultation concerning known or suspected impacts to state-listed fauna. 


\section{REFERENCES}

Baranski, M. J. 2009. Natural Areas Analysis and Evaluation: Oak Ridge Reservation. ORNL/TM2009/201, Oak Ridge National Laboratory, Oak Ridge, Tennessee. DOI: 10.2172/1023815.

Baranski, M. J. 2011. Aquatic Natural Areas Analysis and Evaluation: Oak Ridge Reservation. ORNL/TM-2011/13, Oak Ridge National Laboratory, Oak Ridge, Tennessee. DOI: 10.2172/1023838.

Baranski, M. J. 2018. Natural Areas Analysis and Evaluation: Oak Ridge Reservation. Oak Ridge National Laboratory, Oak Ridge, Tennessee. Not for public release.

Carter, E. T., G. Byrd, S. Darling, K. McCracken, L. Pounds, and N. R. Giffen. 2019. Natural Resources Assessment for the Proposed Spallation Neutron Source Second Target Station: Supplement to the 1999 SNS Environmental Impact Statement. Oak Ridge National Laboratory, Oak Ridge, Tennessee.

Carter, E. T., N. R. Giffen, K. McCracken, S. E. Darling, A. Deck, G. Byrd. 2020. Wildlife Management Plan for the Oak Ridge Reservation. ORNL/TM-2012/387/R1, Oak Ridge National Laboratory, Oak Ridge, Tennessee.

Chester, E. W., E. B. Wofford, J. Shaw, D. Estes, and D. H. Webb. 2015. Guide to the Vascular Plants of Tennessee. University of Tennessee Press. Knoxville, Tennessee.

Cowardin, L. M., V. Carter, F. C. Golet, and E. T. LaRoe. 1979. Classification of wetlands and deepwater habitats of the United States. FWS/OBS-79/31. US Fish and Wildlife Service, Washington, DC.

DeRolph, C. R., E. T. Carter, M. K. McCracken, G. Byrd, J. M. Herold, R. T. Jett, S. Darling, N. S. Gladstone, N. R. Giffen, T. J. Mathews, and M. J. Peterson. 2019a. Natural Resource Assessment for the Proposed Central Borrow Area, Oak Ridge, Tennessee. ORNL/TM-2019/1257, Oak Ridge National Laboratory, Oak Ridge, Tennessee.

DeRolph, C. R., E. T. Carter, M. K. McCracken, G. Byrd, J. M. Herold, R. T. Jett, S. Darling, N. R. Giffen, T. J. Mathews, and M. J. Peterson. 2019b. Preliminary Mitigation Screening for the On-Site Waste Disposal Facility and Central Borrow Area, Oak Ridge, Tennessee. ORNL/TM-2019/1260, Oak Ridge National Laboratory, Oak Ridge, Tennessee.

Giffen, N. R., J. W. Evans, and P. D. Parr. 2012. Wildlife Management Plan for the Oak Ridge Reservation. ORNL/TM-2012/387, Oak Ridge National Laboratory, Oak Ridge, Tennessee.

McCracken, M. K., N. R. Giffen, A. M. Haines, B. J. Guge, and J. W. Evans. 2015. Bat Species Distribution on the Oak Ridge Reservation. ORNL/TM-2015/248, Oak Ridge National Laboratory, Oak Ridge, Tennessee.

McRae, B. H., V. B. Shah, and T. K. Mohapatra. 2013. Circuitscape 4 User Guide. The Nature Conservancy. http://www.circuitscape.org.

Parr, P. D., G. S. Byrd, J. W. Johnston, Jr., N. R. Giffen. 2015. Forest Management Plan for the DOE Oak Ridge Reservation: An Interdisciplinary Approach for Managing a Heritage Resource. ORNL/TM-2015/98, Oak Ridge National Laboratory, Oak Ridge, Tennessee.

Partners in Flight. 2020. Avian Conservation Assessment Database, version 2020. Available at http://pif.birdconservancy.org/ACAD. Accessed on July 31, 2020.

Pasachnik, S. and M. L. Niemiller. 2011. "Four-toed Salamanders (Hemidactylium scutatum)." In The Amphibians of Tennessee. M. L. Niemiller and R. G. Reynolds (Eds.) University of Tennessee Press. Knoxville, Tennessee.

Peterson, M. J., J. M. Herold, M. K. McCracken, R. T. Jett, G. Byrd, S. Darling, B. Guge, N. R. Giffen, C. R. DeRolph. 2018. Natural Resource Assessment for the Proposed Environmental Management 
Disposal Facility (EMDF). ORNL/TM-2018/515, Oak Ridge National Laboratory, Oak Ridge, Tennessee.

Peterson, M. J., N. R. Giffen, M. G. Ryon, L. R. Pounds, E. L. Ryan. 2005. Environmental Survey Report for the ETTP: Environmental Management Waste Management Facility (EMWMF) Haul Road Corridor. ORNL/TM-2005/215, Oak Ridge National Laboratory, Oak Ridge, Tennessee.

Rosensteel, B. A. 1996. Wetland Survey of the X-10 Bethel Valley and Melton Valley Groundwater Operable Units at Oak Ridge National Laboratory, Oak Ridge, Tennessee. ORNL/ER-350. Oak Ridge National Laboratory, Oak Ridge, Tennessee. https://www.osti.gov/servlets/purl/224263

Roy, W. K., N. R. Giffen, M. C. Wade, A. M. Haines, J. W. Evans, R. T. Jett. 2014. ORR Bird Records and Population Trends. ORNL/TM-2014/109. Oak Ridge National Laboratory, Oak Ridge, Tennessee.

TDEC (Tennessee Department of Environment and Conservation). 2016. Tennessee Natural Heritage Program Rare Plant List, TDEC Division of Natural Areas, Nashville, Tennessee. https://www.tn.gov/content/dam/tn/environment/documents/na rare-plant-list-2016.pdf.

TDEC (Tennessee Department of Environment and Conservation). 2019. Stream Mitigation Guidelines. https://www.tn.gov/content/dam/tn/environment/water/policy-and-guidance/dwr-nr-g-01-streammitigation-guidelines-052019.pdf.

TDEC (Tennessee Department of Environment and Conservation). 2020. Guidance for Making Hydrologic Determinations Version 1.5. Division of Water Pollution Control, Nashville, Tennessee. https://www.tn.gov/content/dam/tn/environment/water/policy-and-guidance/dwr-nr-g-03-hydrologicdeterminations \%E2\%80\%9304012020.pdf.

TDEC (Tennessee Department of Environment and Conservation). Tennessee Rapid Assessment Method (TRAM.) 2015. Division of Water Resources Natural Resources Unit, Nashville, Tennessee.

TWRA (Tennessee Wildlife Resources Agency). 2016. Threatened and Endangered Species List Rules. Available at https://www.tn.gov/content/tn/twra/wildlife.html\#endangered. Accessed on July 12, 2020.

TWRA (Tennessee Wildlife Resources Agency). 2018. Chapter 1660-01-32, Rules of the Tennessee Wildlife Resources Agency: Biodiversity. Nashville, Tennessee.

USACE (US Army Corps of Engineers) 2018. National Wetland Plant List, version 3.4. Engineer Research and Development Center. Cold Regions Research and Engineering Laboratory, Hanover, New Hampshire http://wetland-plants.usace.army.mil/.

USACE (US Army Corps of Engineers) 2018. National Wetland Plant List, version 3.4. Engineer Research and Development Center. Cold Regions Research and Engineering Laboratory, Hanover, New Hampshire http://wetland-plants.usace.army.mil/.

USACE (US Army Corps of Engineers) 2018. National Wetland Plant List, version 3.4. Engineer Research and Development Center. Cold Regions Research and Engineering Laboratory, Hanover, New Hampshire http://wetland-plants.usace.army.mil/.

USACE (US Army Corps of Engineers). 1987. Wetlands Delineation Manual. Technical Report Y-87-1. Waterways Experiment Station, Vicksburg, Mississippi.

USDA (US Department of Agriculture), NRCS (Natural Resources Conservation Service). 2016. The PLANTS Database. National Plant Data Team, Greensboro, North Carolina. http://plants.usda.gov. Accessed on July 10, 2020.

USDA, NRCS. 2016. The PLANTS Database (http://plants.usda.gov, 7/10/20). National Plant Data Team, Greensboro, North Carolina. http://plants.usda.gov. 
USFWS (US Fish and Wildlife Service). 2011. "Birds of Management Concern and Focal Species." Available at https://www.fws.gov/migratorybirds/pdf/management/BMCFocalSpecies.pdf. Accessed on 1 February 2020.

USFWS (US Fish and Wildlife Service). 2017. Conservation Strategy for Forest-dwelling Bats in Tennessee. Available at https://www.fws.gov/cookeville/pdfs/TN Conserv Strat forest dwelling bats 171005.pdf. Accessed on July 12, 2020.

USFWS (US Fish and Wildlife Service). 2020. ECOS Environmental Conservation Online System. Retrieved from https://ecos.fws.gov/ecp0/reports/ad-hoc-species-report-input. Accessed on 1 February 2020.

USFWS (US Fish and Wildlife Service). 2020. Endangered Species. Retrieved from https://www.fws.gov/endangered/index.html. Accessed on July 1, 2020.

Wade, B. and E. T. Carter. 2020. Modelling barriers to aquatic-terrestrial wildlife movement on the Oak Ridge Reservation. Oak Ridge National Laboratory, Oak Ridge, Tennessee.

Wade, B., C. R. DeRolph, and E. T. Carter. In preparation. Optimizing connectivity of imperiled fourtoed salamanders (Hemidactylium scutatum) on the Oak Ridge Reservation, Oak Ridge National Laboratory, Oak Ridge, Tennessee. 


\section{APPENDIX I. PRE-SURVEY SCREENING OF FEDERALLY LISTED TAXA, HABITAT SUITABILITY, AND HISTORICAL AND CONTEMPORARY PRESENCE WITHIN THE VTR CONSTRUCTION AREA}

Table I.1. Federally listed species with the potential to occur within the VTR construction area. Table A1.2 includes BCC or BMC.

\begin{tabular}{|c|c|c|c|c|c|c|c|}
\hline $\begin{array}{c}\text { Common } \\
\text { name }\end{array}$ & $\begin{array}{l}\text { Scientific } \\
\text { name }\end{array}$ & Status & $\begin{array}{c}\text { ECOS } \\
\text { doc }\end{array}$ & $\begin{array}{c}\text { ORR } \\
\text { historical }\end{array}$ & $\begin{array}{c}\text { Habitat } \\
\text { within VTR } \\
\text { project area }\end{array}$ & $\begin{array}{c}\text { VTR } \\
\text { confirmed } \\
\text { contemporary }\end{array}$ & $\begin{array}{l}\text { Notes/ } \\
\text { suspected } \\
\text { Impacts }\end{array}$ \\
\hline \multicolumn{8}{|l|}{ Amphibians } \\
\hline $\begin{array}{l}\text { Berry Cave } \\
\text { salamander }\end{array}$ & $\begin{array}{l}\text { Gyrinophilus } \\
\text { gulolineatus }\end{array}$ & $\mathrm{CS}$ & $\begin{array}{l}\frac{\text { Link }}{\text { Link }} \\
\underline{\text { Link }}\end{array}$ & no & $\begin{array}{l}\text { Underlying } \\
\text { karst and } \\
\text { aquatic } \\
\text { subterranean } \\
\text { habitat exists, } \\
\text { but a lack of } \\
\text { human- } \\
\text { accessible caves } \\
\text { might prevent } \\
\text { detection under } \\
\text { the provided } \\
\text { timeline }\end{array}$ & No* & $\begin{array}{l}\text { Disturbance of } \\
\text { deeper karst and } \\
\text { groundwater } \\
\text { would be } \\
\text { detrimental to this } \\
\text { and other } \\
\text { subterranean taxa }\end{array}$ \\
\hline \multicolumn{8}{|l|}{ Mammals } \\
\hline Gray bat & $\begin{array}{l}\text { Myotis } \\
\text { grisescens }\end{array}$ & $\mathrm{FE}$ & $\underline{\text { Link }}$ & Yes & Foraging habitat & Yes & $\begin{array}{c}\text { Known } \\
\text { hibernaculum and } \\
\text { maternity habitat } \\
\text { within } 0.5 \text { miles } \\
\text { of project area }\end{array}$ \\
\hline Indiana bat & Myotis sodalis & $\mathrm{FE}$ & $\underline{\text { Link }}$ & Yes & $\begin{array}{c}\text { Foraging and } \\
\text { maternity } \\
\text { habitat }\end{array}$ & Probable $^{\dagger}$ & $\begin{array}{c}\text { Probable } \\
\text { hibernacula within } \\
\text { regulatory limits } \\
\text { of project area- } \\
\text { numerous caves } \\
\text { with previous } \\
\text { observations }\end{array}$ \\
\hline $\begin{array}{l}\text { Northern } \\
\text { long-eared bat }\end{array}$ & $\begin{array}{l}\text { Myotis } \\
\text { septentrionalis }\end{array}$ & FT & $\underline{\text { Link }}$ & Yes & $\begin{array}{c}\text { Foraging and } \\
\text { maternity } \\
\text { habitat }\end{array}$ & Probable $^{\dagger}$ & $\begin{array}{c}\text { Suitable } \\
\text { hibernaculum } \\
\text { within } 0.5 \text { miles } \\
\text { of project area }\end{array}$ \\
\hline Tricolored bat & $\begin{array}{l}\text { Perimyotis } \\
\text { subflavus }\end{array}$ & UR & $\underline{\text { Link }}$ & Yes & Foraging habitat & Yes & \\
\hline $\begin{array}{l}\text { Little brown } \\
\text { bat }\end{array}$ & $\begin{array}{l}\text { Myotis } \\
\text { lucifugus }\end{array}$ & UR & $\underline{\text { Link }}$ & Yes & Forging habitat & Yes & \\
\hline \multicolumn{8}{|l|}{ Clams } \\
\hline $\begin{array}{l}\text { Alabama } \\
\text { lampmussel }\end{array}$ & $\begin{array}{l}\text { Lampsilis } \\
\text { virescens }\end{array}$ & $\mathrm{FE}$ & $\underline{\text { Link }}$ & No & No & No & No impact \\
\hline
\end{tabular}


Table I.1. Federally listed species with the potential to occur within the VTR construction area (continued). Table A1.2 includes BCC or BMC.

\begin{tabular}{|c|c|c|c|c|c|c|c|}
\hline $\begin{array}{c}\text { Common } \\
\text { name }\end{array}$ & $\begin{array}{l}\text { Scientific } \\
\text { name }\end{array}$ & Status & $\begin{array}{l}\text { ECOS } \\
\text { doc }\end{array}$ & $\begin{array}{c}\text { ORR } \\
\text { historical }\end{array}$ & $\begin{array}{c}\text { Habitat } \\
\text { within VTR } \\
\text { project area }\end{array}$ & $\begin{array}{c}\text { VTR } \\
\text { confirmed } \\
\text { contemporary }\end{array}$ & $\begin{array}{l}\text { Notes/ } \\
\text { suspected } \\
\text { Impacts }\end{array}$ \\
\hline $\begin{array}{l}\text { Cracking } \\
\text { pearlymussel }\end{array}$ & Hemistena lata & $\mathrm{FE}$ & $\underline{\text { Link }}$ & No & No & No & No impact \\
\hline $\begin{array}{l}\text { Dromedary } \\
\text { pearlymussel }\end{array}$ & $\begin{array}{l}\text { Dromus } \\
\text { dromas }\end{array}$ & $\mathrm{FE}$ & $\underline{\text { Link }}$ & Yes & No & No & Low to no impact \\
\hline Fanshell & $\begin{array}{l}\text { Cyprogenia } \\
\text { stegaria }\end{array}$ & $\mathrm{FE}$ & $\underline{\text { Link }}$ & Yes & No & No & Low to no impact \\
\hline $\begin{array}{l}\text { Finerayed } \\
\text { pigtoe }\end{array}$ & $\begin{array}{l}\text { Fusconaia } \\
\text { cuneolus }\end{array}$ & $\mathrm{FE}$ & $\underline{\text { Link }}$ & Yes & No & No & Low to no impact \\
\hline $\begin{array}{l}\text { Orangefoot } \\
\text { pimpleback }\end{array}$ & $\begin{array}{l}\text { Plethobasus } \\
\text { cooperianus }\end{array}$ & $\mathrm{FE}$ & $\underline{\text { Link }}$ & Yes & No & No & Low to no impact \\
\hline Pink mucket & $\begin{array}{l}\text { Lampsilis } \\
\text { abrupta }\end{array}$ & $\mathrm{FE}$ & $\underline{\text { Link }}$ & Yes & No & No & Low to no impact \\
\hline Ring pink & $\begin{array}{l}\text { Obovaria } \\
\text { retusa }\end{array}$ & FE & $\underline{\text { Link }}$ & No & No & No & No impact \\
\hline Rough pigtoe & $\begin{array}{l}\text { Pleurobema } \\
\text { plenum }\end{array}$ & FE & $\underline{\text { Link }}$ & No & No & No & No impact \\
\hline $\begin{array}{l}\text { Rough } \\
\text { rabbitsfoot }\end{array}$ & $\begin{array}{l}\text { Quadrula } \\
\text { cylindrica } \\
\text { strigillata }\end{array}$ & $\mathrm{FE}$ & $\underline{\text { Link }}$ & Yes & No & No & Low to no impact \\
\hline $\begin{array}{l}\text { Sheepnose } \\
\text { Mussel }\end{array}$ & $\begin{array}{l}\text { Plethobasus } \\
\text { cyphyus }\end{array}$ & $\mathrm{FE}$ & $\underline{\text { Link }}$ & Yes & No & No & Low to no impact \\
\hline shiny pigtoe & Fusconaia cor & $\mathrm{FE}$ & $\underline{\text { Link }}$ & Yes & No & No & Low to no impact \\
\hline Spectaclecase & $\begin{array}{l}\text { Cumberlandia } \\
\text { monodonta }\end{array}$ & $\mathrm{FE}$ & $\underline{\text { Link }}$ & Yes & No & No & Low to no impact \\
\hline $\begin{array}{l}\text { White } \\
\text { wartyback }\end{array}$ & $\begin{array}{l}\text { Plethobasus } \\
\text { cicatricosus }\end{array}$ & FE & $\underline{\text { Link }}$ & No & No & No & No impact \\
\hline \multicolumn{8}{|l|}{ Snails } \\
\hline $\begin{array}{l}\text { Anthony's } \\
\text { riversnail }\end{array}$ & $\begin{array}{l}\text { Athearnia } \\
\text { anthonyi }\end{array}$ & $\mathrm{FE}$ & $\underline{\text { Link }}$ & No & No & No & No impact \\
\hline $\begin{array}{l}\text { Spiny } \\
\text { riversnail }\end{array}$ & Io fluvialis & UR & $\underline{\text { Link }}$ & Yes & No & No & Low to no impact \\
\hline \multicolumn{8}{|c|}{ Flowering plants } \\
\hline $\begin{array}{l}\text { Virginia } \\
\text { spiraea }\end{array}$ & $\begin{array}{l}\text { Spiraea } \\
\text { virginiana }\end{array}$ & FT & $\underline{\text { Link }}$ & No & $\begin{array}{l}\text { Several streams } \\
\text { with high } \\
\text { degree of } \\
\text { scouring from } \\
\text { periodic flood, } \\
\text { many areas } \\
\text { resulting in low } \\
\text { potential for } \\
\text { competition } \\
\text { from woody } \\
\text { vegetation }\end{array}$ & No & No impact \\
\hline
\end{tabular}


Table I.1. Federally listed species with the potential to occur within the VTR construction area (continued). Table A1.2 includes BCC or BMC.

\begin{tabular}{|c|c|c|c|c|c|c|c|}
\hline $\begin{array}{c}\text { Common } \\
\text { name }\end{array}$ & $\begin{array}{l}\text { Scientific } \\
\text { name }\end{array}$ & Status & $\begin{array}{c}\text { ECOS } \\
\text { doc }\end{array}$ & $\begin{array}{c}\text { ORR } \\
\text { historical }\end{array}$ & $\begin{array}{c}\text { Habitat } \\
\text { within VTR } \\
\text { project area }\end{array}$ & $\begin{array}{c}\text { VTR } \\
\text { confirmed } \\
\text { contemporary }\end{array}$ & $\begin{array}{c}\text { Notes/ } \\
\text { suspected } \\
\text { Impacts }\end{array}$ \\
\hline $\begin{array}{l}\text { White } \\
\text { fringeless } \\
\text { orchid }\end{array}$ & $\begin{array}{l}\text { Platanthera } \\
\text { integrilabia }\end{array}$ & FT & $\underline{\text { Link }}$ & No & $\begin{array}{l}\text { Several seepy, } \\
\text { boggy wetlands } \\
\text { within the VTR } \\
\text { construction } \\
\text { area provide } \\
\text { ideal habitat for } \\
\text { this species }\end{array}$ & Possible & $\begin{array}{c}\text { Possible } \\
\text { Platanthera spp } \\
\text { sprouts observed } \\
\text { in March } 2020 \text { in } \\
\text { wetlands within } \\
\text { project area. } \\
\text { Could not yet be } \\
\text { identified to } \\
\text { species level }\end{array}$ \\
\hline
\end{tabular}

* Could not confirm because of no known human accessible caves within project area. Does not preclude occurrence.

$\dagger$ Record based on few acoustic monitor detections, but presence is assumed given habitat and nearby records.

\$ Timing of surveys did not permit positive identification because diagnostic characters are largely absent during spring/early summer.

ECOS: Environmental Conservation Online System. Federal listing status codes: FE: federally listed Endangered species; FT: federally listed Threatened species; UR: currently under review for federal listing; CS: species is not listed or under review currently but continues to be a candidate species for federal listing owing to insufficient data. 
Table I.2. State-listed taxa, sensitive communities, and focal species on the ORR. The state of Tennessee adopts by default all federally listed species statuses (see Table A1.1 for federally listed taxa).

\begin{tabular}{|c|c|c|c|c|c|c|}
\hline Common name & Scientific name & Status & $\begin{array}{l}\text { Other } \\
\text { protection } \\
\text { status }\end{array}$ & $\begin{array}{c}\text { ORR } \\
\text { historical }\end{array}$ & $\begin{array}{c}\text { Habitat } \\
\text { within VTR } \\
\text { project area }\end{array}$ & $\begin{array}{c}\text { VTR } \\
\text { confirmed } \\
\text { contemporary }\end{array}$ \\
\hline \multicolumn{7}{|l|}{ Amphibians } \\
\hline $\begin{array}{l}\text { Green } \\
\text { salamander }\end{array}$ & Aneides aeneus & $\mathrm{R}$ & S3S4 & Yes & $\begin{array}{l}\text { Unlikely; minimal } \\
\text { availability of } \\
\text { damp crevices in } \\
\text { shaded rock } \\
\text { outcrops and } \\
\text { ledges; beneath } \\
\text { loose bark and } \\
\text { cracks of trees; } \\
\text { and sometimes } \\
\text { in/or under logs }\end{array}$ & No \\
\hline Hellbender & $\begin{array}{l}\text { Cryptobranchus } \\
\text { alleganiensis }\end{array}$ & $\mathrm{E}$ & S3 & Yes & No & No \\
\hline $\begin{array}{l}\text { Berry Cave } \\
\text { salamander }\end{array}$ & $\begin{array}{l}\text { Gyrinophilus } \\
\text { gulolineatus }\end{array}$ & $\mathrm{T}$ & S1 & No & $\begin{array}{l}\text { Possible;* but } \\
\text { aquatic } \\
\text { subterranean } \\
\text { habitat present }\end{array}$ & $\mathrm{No}^{*}$ \\
\hline $\begin{array}{l}\text { Four-toed } \\
\text { salamander }\end{array}$ & $\begin{array}{l}\text { Hemidactylium } \\
\text { scutatum }\end{array}$ & SD & $\begin{array}{c}\text { S3; } \\
\text { populations on } \\
\text { ORR are the } \\
\text { subject of } \\
\text { ongoing } \\
\text { research }\end{array}$ & Yes & $\begin{array}{l}\text { Yes; moist forest } \\
\text { and sphagnum in } \\
\text { and along all } \\
\text { wetlands and } \\
\text { slow-moving } \\
\text { waterways within } \\
\text { project area }\end{array}$ & Yes \\
\hline Mud salamander & $\begin{array}{l}\text { Pseudotriton } \\
\text { montanus }\end{array}$ & $\mathrm{R}$ & $\begin{array}{l}\text { Populations on } \\
\text { ORR are the } \\
\text { subject of } \\
\text { ongoing } \\
\text { research }\end{array}$ & unknown & $\begin{array}{l}\text { Yes; headwater } \\
\text { streams, seepages, } \\
\text { and mucky } \\
\text { wetlands } \\
\text { throughout } \\
\text { project area }\end{array}$ & Yes \\
\hline \multicolumn{7}{|l|}{ Arachnids } \\
\hline A cave spider & $\begin{array}{l}\text { Nesticus } \\
\text { paynei/tennesseen } \\
\text { sis }\end{array}$ & $\mathrm{R}$ & $\mathrm{S} 3, \mathrm{~S} 2 \mathrm{~S} 4$ & Yes & $\begin{array}{l}\text { Unlikely; } \\
\text { terrestrial cave } \\
\text { obligate }\end{array}$ & $\mathrm{No}^{*}$ \\
\hline $\begin{array}{l}\text { Southeastern } \\
\text { cave } \\
\text { pseudoscorpion }\end{array}$ & $\begin{array}{l}\text { Hersperochernes } \\
\text { mirabilis }\end{array}$ & $\mathrm{R}$ & S3 & No & $\begin{array}{l}\text { Unlikely; } \\
\text { terrestrial cave } \\
\text { obligate }\end{array}$ & No* \\
\hline \multicolumn{7}{|l|}{ Crustaceans } \\
\hline cave isopods & $\begin{array}{c}\text { Caecodotea } \\
\text { incurva/recurvata }\end{array}$ & $\mathrm{R}$ & $\mathrm{S} 1, \mathrm{~S} 2$ & Unknown & $\begin{array}{l}\text { Yes; aquatic } \\
\text { subterranean }\end{array}$ & Yes \\
\hline \multicolumn{7}{|l|}{ Insects } \\
\hline $\begin{array}{l}\text { Cave beetle } \\
\text { (multiple species, } \\
\text { including one yet } \\
\text { to be described) }\end{array}$ & $\begin{array}{c}\text { Pseudanophthalm } \\
\text { us spp }\end{array}$ & $\mathrm{R}$ & $\mathrm{S} 1-\mathrm{S} 3$ & Yes & $\begin{array}{l}\text { Yes; troglobitic, } \\
\text { typically along } \\
\text { subterranean } \\
\text { streams }\end{array}$ & No* \\
\hline
\end{tabular}


Table I.2. State-listed taxa, sensitive communities, and focal species on the ORR (continued). The state of Tennessee adopts by default all federally listed species statuses (see Table A1.1 for federally listed taxa).

\begin{tabular}{|c|c|c|c|c|c|c|}
\hline Common name & Scientific name & Status & $\begin{array}{c}\text { Other } \\
\text { protection } \\
\text { status }\end{array}$ & $\begin{array}{c}\text { ORR } \\
\text { historical }\end{array}$ & $\begin{array}{c}\text { Habitat } \\
\text { within VTR } \\
\text { project area }\end{array}$ & $\begin{array}{c}\text { VTR } \\
\text { confirmed } \\
\text { contemporary }\end{array}$ \\
\hline \multicolumn{7}{|l|}{ Mammals } \\
\hline $\begin{array}{l}\text { Allegheny } \\
\text { woodrat }\end{array}$ & Neotoma magister & SD & S3 & Yes & $\begin{array}{l}\text { Yes; outcrops, } \\
\text { cliffs, talus } \\
\text { slopes, crevices, } \\
\text { sinkholes, caves, } \\
\text { and karst } \\
\text { Observations } \\
\text { exist in caves just } \\
\text { outside project } \\
\text { area }\end{array}$ & Probable \\
\hline $\begin{array}{l}\text { Rafinesque's big- } \\
\text { eared bat }\end{array}$ & $\begin{array}{l}\text { Corynorhinus } \\
\text { rafinesquii }\end{array}$ & SD & S3S4 & Yes & $\begin{array}{l}\text { Yes; caves, } \\
\text { hollow trees, } \\
\text { abandoned } \\
\text { buildings; often } \\
\text { associated with } \\
\text { forested areas } \\
\text { Calls recorded } \\
\text { near site }\end{array}$ & Yes \\
\hline Gray bat & Myotis grisescens & $\mathrm{E}$ & $\begin{array}{c}\text { See Table } \\
\text { A1.1 }\end{array}$ & Yes & Yes & Yes \\
\hline $\begin{array}{l}\text { Eastern small- } \\
\text { footed bat }\end{array}$ & Myotis leibii & SD & & Yes & Yes & Yes \\
\hline Little brown bat & Myotis lucifugus & $\mathrm{T}$ & $\begin{array}{c}\text { See Table } \\
\text { A1.1 }\end{array}$ & Yes & Yes & Yes \\
\hline Little brown bat & Myotis lucifugus & $\mathrm{T}$ & $\begin{array}{c}\text { See Table } \\
\text { A1.1 }\end{array}$ & Yes & Yes & Yes \\
\hline $\begin{array}{l}\text { Northern long- } \\
\text { eared bat }\end{array}$ & $\begin{array}{c}\text { Myotis } \\
\text { septentrionalis }\end{array}$ & $\mathrm{T}$ & $\begin{array}{l}\text { See Table } \\
\text { A1.1 }\end{array}$ & Yes & Yes & Probable $^{\dagger}$ \\
\hline Indiana bat & Myotis sodalis & $\mathrm{E}$ & $\begin{array}{l}\text { See Table } \\
\text { A1.1 }\end{array}$ & Yes & Yes & Probable $^{\dagger}$ \\
\hline Tri-colored bat & $\begin{array}{l}\text { Perimyotis } \\
\text { subflavus }\end{array}$ & $\mathrm{T}$ & $\begin{array}{l}\text { See Table } \\
\text { A1.1 }\end{array}$ & Yes & Yes & Yes \\
\hline $\begin{array}{l}\text { Southern bog } \\
\text { lemming }\end{array}$ & $\begin{array}{c}\text { Synaptomys } \\
\text { cooperi }\end{array}$ & SD & S4 & $\begin{array}{c}\text { Yes } \\
\text { (pre-1995) }\end{array}$ & $\begin{array}{l}\text { Yes; marshy } \\
\text { meadows, wet } \\
\text { balds, and rich } \\
\text { upland forests } \\
\text { (especially in } \\
\text { northern and } \\
\text { eastern portion of } \\
\text { project area) }\end{array}$ & No \\
\hline \multicolumn{7}{|l|}{ Birds } \\
\hline Bald eagle & $\begin{array}{c}\text { Haliaeetus } \\
\text { leucocephalus }\end{array}$ & $\mathrm{SD}$ & $\begin{array}{l}\text { BCC, BGEPA, } \\
\text { FS, BMC, } \\
\text { MBTA }\end{array}$ & $\begin{array}{c}\text { Breeding } \\
\text { habitat }\end{array}$ & $\begin{array}{l}\text { Yes; breeding } \\
\text { pairs have been } \\
\text { noted in recent } \\
\text { years }\end{array}$ & Yes \\
\hline
\end{tabular}


Table I.2. State-listed taxa, sensitive communities, and focal species on the ORR (continued). The state of Tennessee adopts by default all federally listed species statuses (see Table A1.1 for federally listed taxa).

\begin{tabular}{|c|c|c|c|c|c|c|}
\hline Common name & Scientific name & Status & $\begin{array}{c}\text { Other } \\
\text { protection } \\
\text { status }\end{array}$ & $\begin{array}{c}\text { ORR } \\
\text { historical }\end{array}$ & $\begin{array}{c}\text { Habitat } \\
\text { within VTR } \\
\text { project area }\end{array}$ & $\begin{array}{c}\text { VTR } \\
\text { confirmed } \\
\text { contemporary }\end{array}$ \\
\hline $\begin{array}{l}\text { Worm-eating } \\
\text { Warbler }\end{array}$ & $\begin{array}{l}\text { Helmitheros } \\
\text { vermivorum }\end{array}$ & SNR & $\begin{array}{l}\text { BCC, BMC, } \\
\text { PIF, MBTA }\end{array}$ & $\begin{array}{c}\text { Breeding } \\
\text { habitat }\end{array}$ & Yes & Yes \\
\hline $\begin{array}{l}\text { Eastern whip- } \\
\text { poor-will }\end{array}$ & $\begin{array}{c}\text { Caprimulgus } \\
\text { vociferus }\end{array}$ & SNR & $\begin{array}{l}\text { BCC, PIF, } \\
\text { MTBA }\end{array}$ & $\begin{array}{c}\text { Breeding } \\
\text { habitat }\end{array}$ & Yes & Yes \\
\hline $\begin{array}{l}\text { Red-headed } \\
\text { woodpecker }\end{array}$ & $\begin{array}{c}\text { Melanerpes } \\
\text { erythrocephalus }\end{array}$ & SNR & BCC, PIF & $\begin{array}{c}\text { Breeding } \\
\text { habitat }\end{array}$ & Yes & Yes \\
\hline $\begin{array}{l}\text { Chuck-will's } \\
\text { widow }\end{array}$ & $\begin{array}{c}\text { Antrostomus } \\
\text { carolinensis }\end{array}$ & SNR & PIF, MBTA & $\begin{array}{c}\text { Breeding } \\
\text { habitat }\end{array}$ & Yes & Yes \\
\hline Wood thrush & $\begin{array}{l}\text { Hylocichla } \\
\text { mustelina }\end{array}$ & NM & $\begin{array}{l}\text { BCC, PIF, } \\
\text { BMC, FS, } \\
\text { MBTA }\end{array}$ & $\begin{array}{l}\text { Breeding } \\
\text { habitat }\end{array}$ & Yes & Yes \\
\hline $\begin{array}{l}\text { Yellow-bellied } \\
\text { sapsucker }\end{array}$ & $\begin{array}{l}\text { Sphyrapicus } \\
\text { varius }\end{array}$ & SNR & $\begin{array}{l}\text { BCC, BMC, } \\
\text { MBTA }\end{array}$ & $\begin{array}{c}\text { Breeding } \\
\text { habitat }\end{array}$ & Yes & Yes \\
\hline $\begin{array}{l}\text { Yellow-billed } \\
\text { cuckoo }\end{array}$ & $\begin{array}{l}\text { Coccyzus } \\
\text { americanus }\end{array}$ & SNR & PIF, MBTA & $\begin{array}{l}\text { Breeding } \\
\text { habitat }\end{array}$ & Yes & Yes \\
\hline $\begin{array}{l}\text { Kentucky } \\
\text { warbler }\end{array}$ & $\begin{array}{l}\text { Geothlypis } \\
\text { formosa }\end{array}$ & SNR & $\begin{array}{l}\text { BCC, PIF, } \\
\text { MBTA }\end{array}$ & $\begin{array}{l}\text { Breeding } \\
\text { habitat }\end{array}$ & Yes & Yes \\
\hline \multicolumn{7}{|l|}{ Plants } \\
\hline $\begin{array}{l}\text { Spreading False- } \\
\text { foxglove }\end{array}$ & Aureolaria patula & $\mathrm{SC}$ & S3 & Yes & $\begin{array}{l}\text { Yes; oak woods } \\
\text { and edges }\end{array}$ & \\
\hline $\begin{array}{l}\text { Pink lady’s- } \\
\text { slipper }\end{array}$ & $\begin{array}{l}\text { Cypripedium } \\
\text { acaule }\end{array}$ & SC-CE & S4 & Yes & $\begin{array}{l}\text { Possible; piney } \\
\text { woods, central } \\
\text { portion of project } \\
\text { area }\end{array}$ & \\
\hline $\begin{array}{l}\text { Appalachian } \\
\text { bugbane }\end{array}$ & $\begin{array}{c}\text { Cimicifuga } \\
\text { rubifolia }\end{array}$ & $\mathrm{R}$ & S3 & Yes & $\begin{array}{l}\text { Yes; rich woods } \\
\text { (especially } \\
\text { northeastern } \\
\text { portion of project } \\
\text { area and west of } \\
\text { HPRR Access } \\
\text { Road) }\end{array}$ & \\
\hline Canada lily & Lilium canadense & $\mathrm{R}(\mathrm{T})$ & $\begin{array}{l}\text { S3; } \\
\text { monitored as } \\
\text { rare for the } \\
\text { ORR }\end{array}$ & Yes & $\begin{array}{l}\text { Yes; rich woods } \\
\text { and seeps }\end{array}$ & \\
\hline Goldenseal & $\begin{array}{l}\text { Hydrastis } \\
\text { canadensis }\end{array}$ & SC-CE & S4 & Yes & $\begin{array}{l}\text { Yes; moist woods } \\
\text { with rich soils } \\
\text { (especially in } \\
\text { shaded valleys in } \\
\text { the southern and } \\
\text { eastern portions } \\
\text { of project area, } \\
\text { and west of } \\
\text { HPRR Access } \\
\text { Road) }\end{array}$ & \\
\hline
\end{tabular}


Table I.2. State-listed taxa, sensitive communities, and focal species on the ORR (continued). The state of Tennessee adopts by default all federally listed species statuses (see Table A1.1 for federally listed taxa).

\begin{tabular}{|c|c|c|c|c|c|c|}
\hline Common name & Scientific name & Status & $\begin{array}{c}\text { Other } \\
\text { protection } \\
\text { status }\end{array}$ & $\begin{array}{c}\text { ORR } \\
\text { historical }\end{array}$ & $\begin{array}{c}\text { Habitat } \\
\text { within VTR } \\
\text { project area }\end{array}$ & $\begin{array}{c}\text { VTR } \\
\text { confirmed } \\
\text { contemporary }\end{array}$ \\
\hline Ginseng & $\begin{array}{c}\text { Panax } \\
\text { quinquefolius }\end{array}$ & SC-CE & S3S4 & Yes & $\begin{array}{l}\text { Yes; especially in } \\
\text { northeastern } \\
\text { portion of project } \\
\text { area and west of } \\
\text { HPRR Access } \\
\text { Road }\end{array}$ & Yes \\
\hline $\begin{array}{l}\text { Tubercled rein } \\
\text { orchid }\end{array}$ & $\begin{array}{l}\text { Platanthera flava } \\
\text { var. herbiola }\end{array}$ & $\mathrm{T}$ & S2 & Yes & $\begin{array}{c}\text { Yes; mucky } \\
\text { seeps, swamps, } \\
\text { and floodplain } \\
\text { throughout } \\
\text { project area }\end{array}$ & $\begin{array}{c}\text { Highly likely } \\
\text { Platanthera spp } \\
\text { sprouts } \\
\text { observed in } \\
\text { project area }\end{array}$ \\
\hline $\begin{array}{l}\text { White fringeless } \\
\text { orchid }\end{array}$ & $\begin{array}{l}\text { Platanthera } \\
\text { integrilabia }\end{array}$ & $\mathrm{E}$ & S2S3 & No & $\begin{array}{l}\text { Yes; several } \\
\text { seepy, boggy } \\
\text { wetlands within } \\
\text { the VTR } \\
\text { construction area } \\
\text { provide ideal } \\
\text { habitat for this } \\
\text { species }\end{array}$ & $\begin{array}{c}\text { Possible } ; \\
\text { Platanthera spp } \\
\text { sprouts } \\
\text { observed in } \\
\text { project area }\end{array}$ \\
\hline $\begin{array}{l}\text { October ladies'- } \\
\text { tresses }\end{array}$ & Spiranthes ovalis & $S$ & SNR & Yes & $\begin{array}{l}\text { Yes; wet to mesic } \\
\text { forests }\end{array}$ & \\
\hline $\begin{array}{l}\text { Northern bush- } \\
\text { honeysuckle }\end{array}$ & Diervilla lonicera & $\mathrm{T}$ & S2 & Yes & $\begin{array}{l}\text { Possible; rocky } \\
\text { woodlands and } \\
\text { bluffs }\end{array}$ & \\
\hline $\begin{array}{l}\text { Northern white } \\
\text { cedar }\end{array}$ & Thuja occidentalis & $\mathrm{SC}, \mathrm{R}$ & S3 & Yes & $\begin{array}{l}\text { Yes; calcareous } \\
\text { rocky seeps, cliffs } \\
\text { (eastern portion of } \\
\text { project area) }\end{array}$ & \\
\hline Butternut & Juglans cinerea & $\mathrm{T}$ & S3 & Yes & $\begin{array}{l}\text { Yes; rich woods } \\
\text { and hollows }\end{array}$ & \\
\hline \multicolumn{7}{|c|}{ Rare plant communities } \\
\hline $\begin{array}{l}\text { Northern white } \\
\text { cedar woodland }\end{array}$ & $\begin{array}{c}\text { Thuja } \\
\text { occidentalis; } \\
\text { various species }\end{array}$ & $\mathrm{R}$ & $\mathrm{G} 2 \mathrm{G} 3, \mathrm{~S} 1$ & Yes & No & No \\
\hline $\begin{array}{l}\text { Ridge and valley } \\
\text { calcareous mixed } \\
\text { mesophytic } \\
\text { forest }\end{array}$ & various species & $\mathrm{R}$ & G3, S3 & Yes & $\begin{array}{l}\text { Yes; but subjected } \\
\text { to disturbance }\end{array}$ & $\begin{array}{l}\text { Yes; integrity } \\
\text { compromised }\end{array}$ \\
\hline \multicolumn{7}{|c|}{ Other plant communities } \\
\hline $\begin{array}{l}\text { Eastern hemlock } \\
\text { treatment area }\end{array}$ & Tsuga canadensis & SNR & $\begin{array}{c}\text { FS; vulnerable } \\
\text { in } \\
\text { Southeastern } \\
\text { United States }\end{array}$ & Yes & $\begin{array}{l}\text { Yes; site contains } \\
37 \text { treated } \\
\text { hemlocks, among } \\
\text { the largest } \\
\text { diameter } \\
\text { hemlocks on the } \\
\text { ORR }\end{array}$ & Yes \\
\hline
\end{tabular}


Table I.2. State-listed taxa, sensitive communities, and focal species on the ORR (continued). The state of Tennessee adopts by default all federally listed species statuses (see Table A1.1 for federally listed taxa).

\begin{tabular}{|c|c|c|c|c|c|c|}
\hline Common name & Scientific name & Status & $\begin{array}{c}\text { Other } \\
\text { protection } \\
\text { status }\end{array}$ & $\begin{array}{c}\text { ORR } \\
\text { historical }\end{array}$ & $\begin{array}{c}\text { Habitat } \\
\text { within VTR } \\
\text { project area }\end{array}$ & $\begin{array}{c}\text { VTR } \\
\text { confirmed } \\
\text { contemporary }\end{array}$ \\
\hline \multicolumn{7}{|l|}{ Reptiles } \\
\hline $\begin{array}{l}\text { Northern pine } \\
\text { snake }\end{array}$ & $\begin{array}{c}\text { Pituophis } \\
\text { melanoleucus }\end{array}$ & $\mathrm{T}$ & S3 & Yes & $\begin{array}{l}\text { Yes; well-drained } \\
\text { sandy soils in } \\
\text { pine/pine-oak } \\
\text { woods }\end{array}$ & No \\
\hline $\begin{array}{l}\text { Eastern slender } \\
\text { glass lizard }\end{array}$ & $\begin{array}{l}\text { Ophisaurus } \\
\text { attentuatus } \\
\text { longicaudus }\end{array}$ & SD & $\mathrm{S} 3$ & Yes & $\begin{array}{l}\text { Yes; dry upland } \\
\text { areas including } \\
\text { brushy, cut-over } \\
\text { woodlands and } \\
\text { grassy fields; } \\
\text { fossorial (eastern } \\
\text { and central } \\
\text { portion of project } \\
\text { area) }\end{array}$ & No \\
\hline \multicolumn{7}{|l|}{ Snails } \\
\hline Cave thorn snail & $\begin{array}{l}\text { Carychium } \\
\text { stygium }\end{array}$ & $\mathrm{R}$ & $\mathrm{S} 2$ & No & $\begin{array}{l}\text { Yes; stygobitic, } \\
\text { Highland Rim and } \\
\text { Cumberland } \\
\text { Plateau }\end{array}$ & No* \\
\hline $\begin{array}{l}\text { A cave obligate } \\
\text { snail }\end{array}$ & $\begin{array}{l}\text { Helicodiscus } \\
\text { notius specus }\end{array}$ & $\mathrm{R}$ & $\mathrm{S} 1$ & No & $\begin{array}{l}\text { Yes; troglobitic, } \\
\text { ridge, valley, and } \\
\text { Eastern Highland } \\
\text { Rim }\end{array}$ & No* \\
\hline
\end{tabular}

* Could not confirm due to no known human accessible caves within project area. Does not preclude occurrence.

$\dagger$ Record based on few acoustic monitor detections, but presence is assumed given habitat and nearby records.

* Timing of surveys did not permit positive identification, because diagnostic characters are largely absent during spring/early summer.

State-listing status codes: SNR: state not ranked; S: sensitive; R: rare; SD: In Need of Management; SC: Of Special Concern; SC-

CE: Of Special Concern-Commercially Exploited; T: Threatened; E: Endangered

Other status codes: BGEPA: Bald and Golden Eagle Protection Act; PIF: has listing status under Partners in Flight 


\section{APPENDIX II. COMPLETE LIST OF VERTEBRATE WILDLIFE DOCUMENTED WITHIN THE VTR CONSTRUCTION AREA}

Table II.1. Vertebrate fauna observed within the VTR construction area since 1995.

\begin{tabular}{|c|c|c|c|c|c|c|}
\hline Type & Scientific name & Common name & State status & State rank & Federal status & Other/global \\
\hline Amphibian & Ambystoma maculatum & Spotted salamander & & & & \\
\hline Amphibian & Anaxyrus americanus & American toad & & & & \\
\hline Amphibian & Desmognathus fuscus complex & Dusky salamander & & & & \\
\hline Amphibian & Eurycea bislineata/wilderae & Two-lined salamander & & & & \\
\hline Amphibian & Hemidactylium scutatum & Four-toed salamander & $\mathrm{D}$ & S3 & & G5 \\
\hline Amphibian & Hyla chrysoscelis & Cope's gray treefrog & & & & \\
\hline Amphibian & Lithobates clamitans & Green frog & & & & \\
\hline Amphibian & Lithobates catesbeianus & American bullfrog & & & & \\
\hline Amphibian & Lithobates palustris & Pickerel frog & & & & \\
\hline Amphibian & Lithobates sphenocephalus & Southern leopard frog & & & & \\
\hline Amphibian & Notphthalmus viridescens & Eastern newt & & & & \\
\hline Amphibian & Plethodon glutinosis & Slimy salamander & & & & \\
\hline Amphibian & Plethodon ventralis & Zigzag salamander & & & & \\
\hline Amphibian & Pseudacris crucifer & Spring peeper & & & & \\
\hline Amphibian & Pseudacris feriarum & Upland chorus frog & & & & \\
\hline Amphibian & Pseudotriton montanus & Mud salamander & & & & \\
\hline Amphibian & Pseudotriton ruber & Red salamander & & & & \\
\hline Bat & Corynorhinus rafinesquii & Rafinesque's big-eared bat & $\mathrm{D}$ & S3 & & G3G4 \\
\hline Bat & Eptesicus fuscus & Big brown bat & & & & \\
\hline Bat & Lasionycteris noctivagans & Silver-haired bat & & & & \\
\hline Bat & Lasiurus borealis & Eastern red bat & & & & \\
\hline Bat & Lasiurus cinereus & Hoary bat & & & & \\
\hline Bat & Lasiurus seminolus & Seminole bat & & & & \\
\hline Bat & Myotis grisescens & Gray bat & $\mathrm{E}$ & S2 & FE & G4 \\
\hline Bat & Myotis leibii & Eastern small-footed bat & $\mathrm{D}$ & $\mathrm{S} 2 \mathrm{~S} 3$ & & G4 \\
\hline
\end{tabular}


Table II.1. Vertebrate fauna observed within the VTR construction area since 1995.

\begin{tabular}{|c|c|c|c|c|c|c|}
\hline Type & Scientific name & Common name & State status & State rank & Federal status & Other/global \\
\hline Bat & Myotis lucifugus & Little brown bat & $\mathrm{T}$ & S3 & UR & $\mathrm{G} 3$ \\
\hline Bat & Myotis septentrionalis & Northern long-eared bat & $\mathrm{T}$ & $\mathrm{S} 1 \mathrm{~S} 2$ & FT & G1G2 \\
\hline Bat & Myotis sodalis & Indiana bat & $\mathrm{E}$ & $\mathrm{S} 1$ & $\mathrm{FE}$ & $\mathrm{G} 2$ \\
\hline Bat & Nycticeius humeralis & Evening bat & & & & \\
\hline Bat & Perimyotis subflavus & Tricolored bat & $\mathrm{T}$ & $\mathrm{S} 2 \mathrm{~S} 3$ & UR & G2G3 \\
\hline Bat & Tadarida brasiliensis & Brazilian free-tailed bat & & & & \\
\hline Bird & Ardea herodias & Great-blue heron & & & & \\
\hline Bird & Branta canadensis & Canada goose & & & & $\mathrm{BMC}$ \\
\hline Bird & Aix sponsa & Wood duck & & & & \\
\hline Bird & Coragyps atratus & Black vulture & & & & \\
\hline Bird & Cathartes aura & Turkey vulture & & & & \\
\hline Bird & Accipiter striatus & Sharp-shinned hawk & & & & \\
\hline Bird & Accipiter cooperii & Cooper's hawk & & & & \\
\hline Bird & Haliaeetus leucocephalus & Bald eagle & $\mathrm{D}$ & $\mathrm{S} 3$ & & $\mathrm{BCC}, \mathrm{BMC} / \mathrm{G} 5$ \\
\hline Bird & Buteo lineatus & Red-shouldered hawk & & & & \\
\hline Bird & Vireo olivaceus & Broad-winged hawk & & & & \\
\hline Bird & Strix varia & Barred owl & & & & \\
\hline Bird & Pandion haliaetus & Osprey & & & & \\
\hline Bird & Megascops asio & Eastern screech owl & & & & \\
\hline Bird & Bubo virginianus & Great horned owl & & & & \\
\hline Bird & Antrostomus carolinensis & Chuck-will's Widow & & & & \\
\hline Bird & Antrostomus vociferus & Whip-poor-will & & & & $\mathrm{BCC}$ \\
\hline Bird & Chordeiles minor & Common nighthawk & & & & \\
\hline Bird & Archilochus colubris & Ruby-throated hummingbird & & & & \\
\hline Bird & Sphyrapicus varius & Yellow-bellied sapsucker & & & & $\mathrm{BCC}, \mathrm{BMC}$ \\
\hline Bird & Melanerpes erythrocephalus & Red-headed woodpecker & & & & BCC \\
\hline Bird & Dryocopus pileatus & Pileated woodpecker & & & & \\
\hline Bird & Melanerpes carolinus & Red-bellied woodpecker & & & & \\
\hline Bird & Picoides pubescens & Downy woodpecker & & & & \\
\hline Bird & Dryobates pubescens & Hairy woodpecker & & & & \\
\hline
\end{tabular}


Table II.1. Vertebrate fauna observed within the VTR construction area since 1995.

\begin{tabular}{|c|c|c|c|c|c|c|}
\hline Type & Scientific name & Common name & State status & State rank & Federal status & Other/global \\
\hline Bird & Coccyzus americanus & Yellow-billed cuckoo & & & & \\
\hline Bird & Colaptes auratus & Northern flicker & & & & \\
\hline Bird & Sitta carolinensis & White-breasted nuthatch & & & & \\
\hline Bird & Falco sparverius & American kestrel & & & & \\
\hline Bird & Contopus virens & Eastern wood-pewee & & & & \\
\hline Bird & Empidonax virescens & Acadian flycatcher & & & & \\
\hline Bird & Myiarchus crinitus & Great crested flycatcher & & & & \\
\hline Bird & Sayornis phoebe & Eastern phoebe & & & & \\
\hline Bird & Tyrannus tyrannus & Eastern kingbird & & & & \\
\hline Bird & Vireo griseus & White-eyed vireo & & & & \\
\hline Bird & Vireo flavifrons & Yellow-throated vireo & & & & \\
\hline Bird & Vireo olivaceus & Red-eyed vireo & & & & \\
\hline Bird & Vireo solitarius & Blue-headed vireo & & & & \\
\hline Bird & Cyanocitta cristata & Blue jay & & & & \\
\hline Bird & Corvus brachyrhynchos & American crow & & & & \\
\hline Bird & Poecile carolinensis & Carolina chickadee & & & & \\
\hline Bird & Baeolophus bicolor & Tufted titmouse & & & & \\
\hline Bird & Hirundo rustica & Barn swallow & & & & \\
\hline Bird & Tachycineta bicolor & Tree swallow & & & & \\
\hline Bird & Regulus satrapa & Golden-crowned kinglet & & & & \\
\hline Bird & Regulus calendula & Ruby-crowned kinglet & & & & \\
\hline Bird & Certhia americana & Brown creeper & & & & \\
\hline Bird & Polioptila caerulea & Blue-gray gnatcatcher & & & & \\
\hline Bird & Troglodytes aedon & House wren & & & & \\
\hline Bird & Troglodytes aedon & Winter wren & & & & \\
\hline Bird & Thryothorus ludovicianus & Carolina wren & & & & \\
\hline Bird & Sturnus vulgaris & European starling & & & & \\
\hline Bird & Dumetella carolinensis & Gray catbird & & & & \\
\hline Bird & Toxostoma rufum & Brown thrasher & & & & \\
\hline Bird & Mimus polyglottos & Northern mockingbird & & & & \\
\hline
\end{tabular}


Table II.1. Vertebrate fauna observed within the VTR construction area since 1995.

\begin{tabular}{|c|c|c|c|c|c|c|}
\hline Type & Scientific name & Common name & State status & State rank & Federal status & Other/global \\
\hline Bird & Sialia sialis & Eastern bluebird & & & & \\
\hline Bird & Catharus ustulatus & Swainson's thrush & & & & \\
\hline Bird & Hylocichla mustelina & Wood thrush & NM & & & $\mathrm{BCC}, \mathrm{BMC}$ \\
\hline Bird & Catharus guttatus & Hermit thrush & & & & \\
\hline Bird & Catharus fuscescens & Veery & & & & \\
\hline Bird & Turdus migratorius & American robin & & & & \\
\hline Bird & Bombycilla cedrorum & Cedar waxwing & & & & \\
\hline Bird & Haemorhous mexicanus & House finch & & & & \\
\hline Bird & Haemorhous purpureus & Purple finch & & & & \\
\hline Bird & Spinus tristis & American goldfinch & & & & \\
\hline Bird & Passerculus sandwichensis & Savannah sparrow & Rare & $\mathrm{S} 1 \mathrm{~B}, \mathrm{~S} 4 \mathrm{~N}$ & & G5 \\
\hline Bird & Melospiza melodia & Song sparrow & & & & \\
\hline Bird & Zonotrichia albicollis & White-throated sparrow & & & & \\
\hline Bird & Spizella pusilla & Field sparrow & & & & \\
\hline Bird & Junco hyemalis & Dark-eyed junco & & & & \\
\hline Bird & Pipilo erythrophthalmus & Eastern towhee & & & & \\
\hline Bird & Icteria virens & Yellow-breasted chat & & & & \\
\hline Bird & Icterus spurius & Orchard oriole & & & & \\
\hline Bird & Agelaius phoeniceus & Red-winged blackbird & & & & \\
\hline Bird & Molothrus ater & Brown-headed cowbird & & & & \\
\hline Bird & Quiscalus quiscula & Common grackle & & & & \\
\hline Bird & Helmitheros vermivorum & Worm-eating warbler & & & & $\mathrm{BCC}, \mathrm{BMC}$ \\
\hline Bird & Setophaga citrina & Hooded warbler & & & & \\
\hline Bird & Setophaga pensylvanica & Chestnut-sided warbler & & & & \\
\hline Bird & Setophaga pinus & Pine warbler & & & & \\
\hline Bird & Vermivora cyanoptera & Blue-winged warbler & & & & $\mathrm{BCC}, \mathrm{BMC}$ \\
\hline Bird & Seiurus aurocapilla & Ovenbird & & & & \\
\hline Bird & Parkesia motacilla & Louisiana waterthrush & & & & \\
\hline Bird & Geothlypis formosa & Kentucky warbler & & & & $\mathrm{BCC}$ \\
\hline Bird & Geothlypis trichas & Common yellowthroat & & & & \\
\hline
\end{tabular}


Table II.1. Vertebrate fauna observed within the VTR construction area since 1995.

\begin{tabular}{|c|c|c|c|c|c|c|}
\hline Type & Scientific name & Common name & State status & State rank & Federal status & Other/global \\
\hline Bird & Setophaga citrina & Hooded warbler & & & & \\
\hline Bird & Setophaga americana & Northern parula & & & & \\
\hline Bird & Setophaga petechia & Yellow warbler & & & & \\
\hline Bird & Cardinalis cardinalis & Northern cardinal & & & & \\
\hline Bird & Setophaga coronata & Yellow-rumped warbler & & & & \\
\hline Bird & Setophaga discolor) & Prairie warbler & & & & \\
\hline Bird & Setophaga virens & Black-throated green warbler & & & & \\
\hline Bird & Piranga olivacea & Scarlet tanager & & & & \\
\hline Bird & Piranga rubra & Summer tanager & & & & \\
\hline Bird & Cardinalis cardinalis & Northern cardinal & & & & \\
\hline Bird & Pheucticus ludovicianus & Rose-breasted grosbeak & & & & \\
\hline Bird & Passerina caerulea & Blue grosbeak & & & & \\
\hline Bird & Passerina cyanea & Indigo bunting & & & & \\
\hline Bird & Zenaida macroura & Mourning dove & & & & $\mathrm{BMC}$ \\
\hline Bird & Meteagris gallopava silvestris & Wild turkey & & & & \\
\hline Mammal & Blarina brevicauda & Short-tailed shrew & & & & \\
\hline Mammal & Canis latrans & Coyote & & & & \\
\hline Mammal & Lynx rufus & Bobcat & & & & \\
\hline Mammal & Mustela frenata & Long-tail weasel & & & & \\
\hline Mammal & Odocoileus virginianus & Deer & & & & \\
\hline Mammal & Peromyscus leucopus & White-footed mouse & & & & \\
\hline Mammal & Peromyscus spp & Peromyscus & & & & \\
\hline Mammal & Procyon lotor & Raccoon & & & & \\
\hline Mammal & Sciurus carolinensis & Eastern gray squirrel & & & & \\
\hline Mammal & Sigmodon hispidus & Cotton rat & & & & \\
\hline Mammal & Sylvilagus floridanus & Eastern cottontail & & & & \\
\hline Mammal & Tamias striatus & Eastern chipmunk & & & & \\
\hline Reptile & Carphophis amoenus & Wormsnake & & & & \\
\hline Reptile & Coluber constrictor & Racer & & & & \\
\hline Reptile & Nerodia sipedon & Watersnake & & & & \\
\hline
\end{tabular}


Table II.1. Vertebrate fauna observed within the VTR construction area since 1995.

\begin{tabular}{|c|c|c|c|c|c|c|}
\hline Type & Scientific name & Common name & State status & State rank & Federal status & Other/globa \\
\hline Reptile & Pantherophis spiloides & Rat snake & & & & \\
\hline Reptile & Plestiodon fasciatus & Five-lined skink & & & & \\
\hline Reptile & Scincella lateralis & Little brown skink & & & & \\
\hline Reptile & Storeria occipitomaculata & Redbellied snake & & & & \\
\hline Reptile & Terrapene carolina & Eastern box turtle & & & & \\
\hline Reptile & Thamnophis sirtalis & Gartersnake & & & & \\
\hline
\end{tabular}

Federal status codes (ESA): FE: federally Endangered; FT: federally Threatened; UR: under federal review for listing under ESA.

State status codes: Rare: considered rare by TDEC; NM: In Need of Management by rule of TWRA; SD: state-listed In Need of Management; ST: state Threatened; SE: state Endangered 


\section{APPENDIX III. ADDITIONAL DETAILS FROM 2013 FOREST INVENTORY}

Table III.1. List of species and live tree basal area statistics for the VTR review area.

\begin{tabular}{l}
\multicolumn{1}{c}{ Scientific Name } \\
Acer rubrum \\
Acer saccharum \\
Aesculus flava \\
Ailanthus altissima \\
Albizia julibrissin \\
Carya cordiformis \\
Carya glabra \\
Carya ovata \\
Carya tomentosa \\
Cercis canadensis \\
Cornus florida \\
Fagus grandifolia \\
Fraxinus americana \\
Juglans nigra \\
Juniperus virginiana \\
Liquidambar styraciflua \\
Liriodendron tulipifera \\
Magnolia acuminata \\
Nyssa sylvatica \\
Ostrya virginiana \\
Oxydendrum arboreum \\
Pinus echinata \\
Pinus strobus \\
Pinus virginiana \\
Platanus occidentalis \\
Prunus serotina \\
Quercus alba \\
Quercus coccinea \\
Quercus falcata \\
Quercus muehlenbergii \\
Quercus rubra \\
Quercus stellata \\
Quercus velutina \\
Sassafras albidum \\
Ulmus americana \\
\end{tabular}

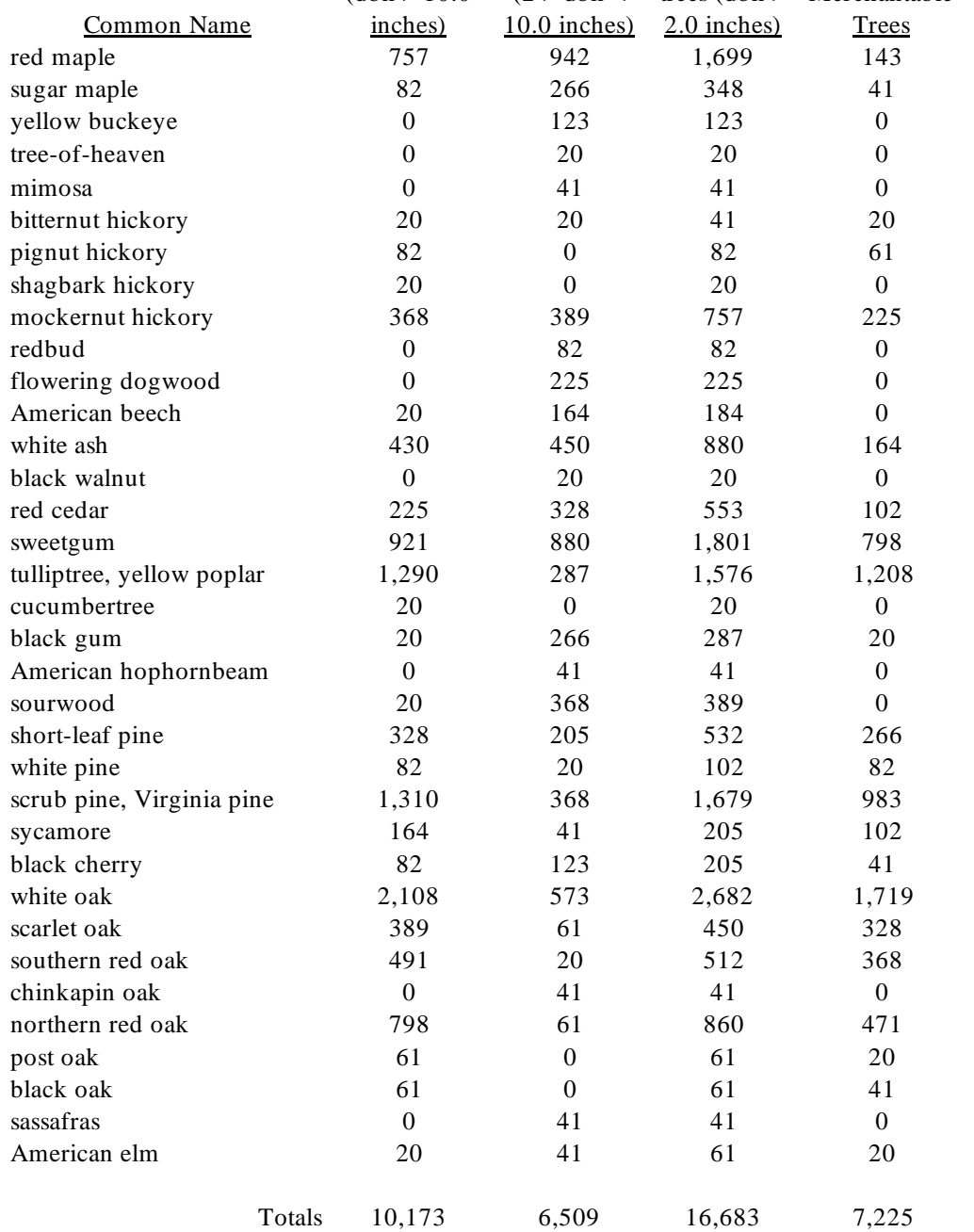

\begin{tabular}{|c|c|c|c|}
\hline $\begin{array}{c}\text { Trees } \\
(\mathrm{dbh}>10.0 \\
\text { inches })\end{array}$ & $\begin{array}{c}\text { Saplings } \\
(2>\text { dbh }< \\
10.0 \text { inches })\end{array}$ & $\begin{array}{c}\text { All tally trees } \\
(\text { dbh }>2.0 \\
\text { inches) }\end{array}$ & $\begin{array}{c}\text { Merchantable } \\
\text { Trees }\end{array}$ \\
\hline$\overline{7 \%}$ & $14 \%$ & $\overline{10 \%}$ & $\overline{2 \%}$ \\
\hline $1 \%$ & $4 \%$ & $2 \%$ & $1 \%$ \\
\hline $0 \%$ & $2 \%$ & $1 \%$ & $0 \%$ \\
\hline $0 \%$ & $0 \%$ & $0 \%$ & $0 \%$ \\
\hline $0 \%$ & $1 \%$ & $0 \%$ & $0 \%$ \\
\hline $0 \%$ & $0 \%$ & $0 \%$ & $0 \%$ \\
\hline $1 \%$ & $0 \%$ & $0 \%$ & $1 \%$ \\
\hline $0 \%$ & $0 \%$ & $0 \%$ & $0 \%$ \\
\hline $4 \%$ & $6 \%$ & $5 \%$ & $3 \%$ \\
\hline $0 \%$ & $1 \%$ & $0 \%$ & $0 \%$ \\
\hline $0 \%$ & $3 \%$ & $1 \%$ & $0 \%$ \\
\hline $0 \%$ & $3 \%$ & $1 \%$ & $0 \%$ \\
\hline $4 \%$ & $7 \%$ & $5 \%$ & $2 \%$ \\
\hline $0 \%$ & $0 \%$ & $0 \%$ & $0 \%$ \\
\hline $2 \%$ & $5 \%$ & $3 \%$ & $1 \%$ \\
\hline $9 \%$ & $14 \%$ & $11 \%$ & $11 \%$ \\
\hline $13 \%$ & $4 \%$ & $9 \%$ & $17 \%$ \\
\hline $0 \%$ & $0 \%$ & $0 \%$ & $0 \%$ \\
\hline $0 \%$ & $4 \%$ & $2 \%$ & $0 \%$ \\
\hline $0 \%$ & $1 \%$ & $0 \%$ & $0 \%$ \\
\hline $0 \%$ & $6 \%$ & $2 \%$ & $0 \%$ \\
\hline $3 \%$ & $3 \%$ & $3 \%$ & $4 \%$ \\
\hline $1 \%$ & $0 \%$ & $1 \%$ & $1 \%$ \\
\hline $13 \%$ & $6 \%$ & $10 \%$ & $14 \%$ \\
\hline $2 \%$ & $1 \%$ & $1 \%$ & $1 \%$ \\
\hline $1 \%$ & $2 \%$ & $1 \%$ & $1 \%$ \\
\hline $21 \%$ & $9 \%$ & $16 \%$ & $24 \%$ \\
\hline $4 \%$ & $1 \%$ & $3 \%$ & $5 \%$ \\
\hline $5 \%$ & $0 \%$ & $3 \%$ & $5 \%$ \\
\hline $0 \%$ & $1 \%$ & $0 \%$ & $0 \%$ \\
\hline $8 \%$ & $1 \%$ & $5 \%$ & $7 \%$ \\
\hline $1 \%$ & $0 \%$ & $0 \%$ & $0 \%$ \\
\hline $1 \%$ & $0 \%$ & $0 \%$ & $1 \%$ \\
\hline $0 \%$ & $1 \%$ & $0 \%$ & $0 \%$ \\
\hline $0 \%$ & $1 \%$ & $0 \%$ & $0 \%$ \\
\hline $100 \%$ & $100 \%$ & $100 \%$ & $100 \%$ \\
\hline
\end{tabular}


Table III.2. Live basal area statistics by genus for the VTR review area.

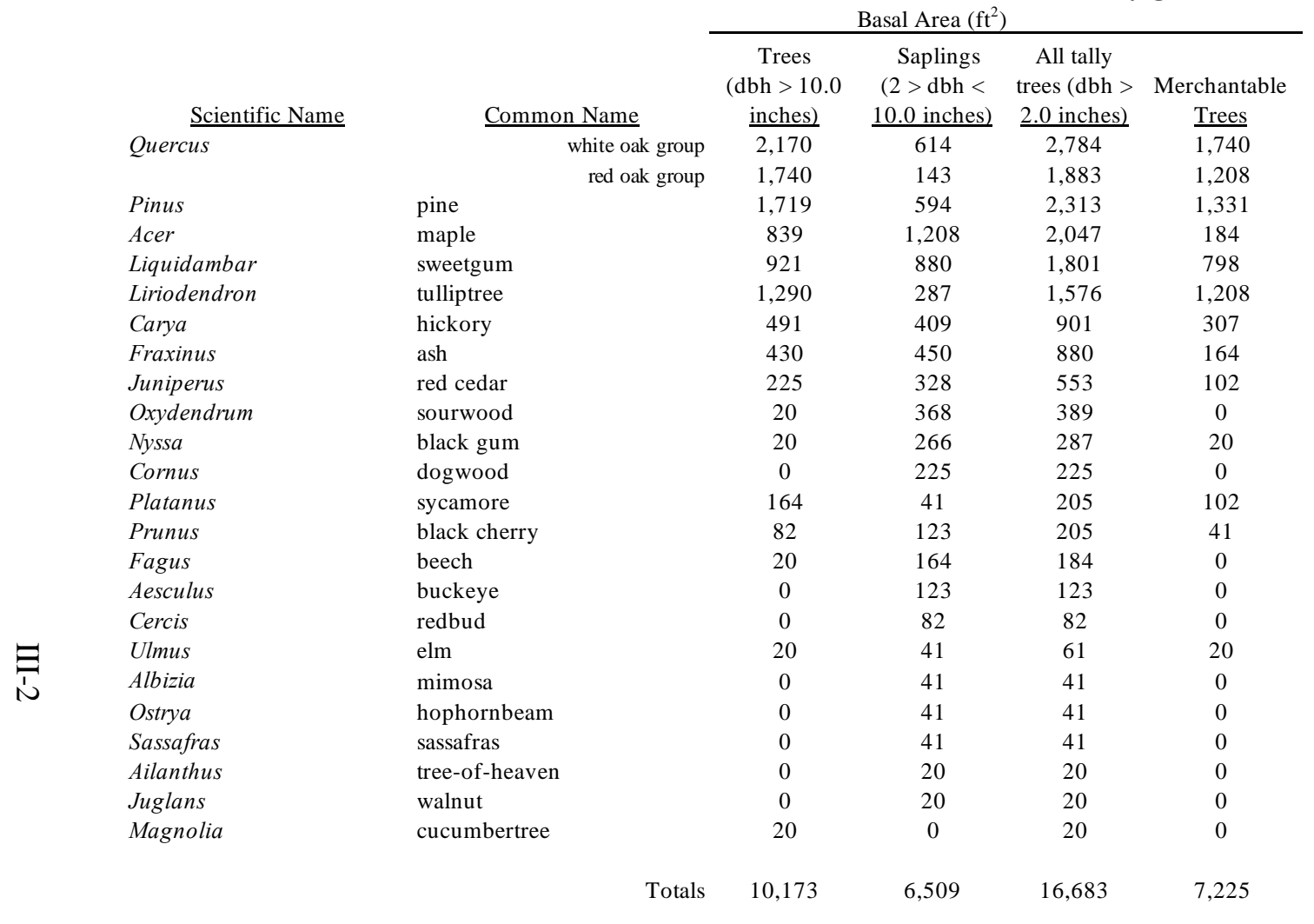

\begin{tabular}{|c|c|c|c|}
\hline \multicolumn{3}{|c|}{ Basal Area $(\%)$} & \multirow[b]{2}{*}{$\begin{array}{c}\text { Merchantable } \\
\text { Trees }\end{array}$} \\
\hline $\begin{array}{c}\text { Trees } \\
(\mathrm{dbh}>10.0 \\
\text { inches })\end{array}$ & $\begin{array}{c}\text { Saplings } \\
(2>\text { dbh }< \\
10.0 \text { inches })\end{array}$ & $\begin{array}{l}\text { All tally trees } \\
\begin{array}{c}\text { (dbh }>\underline{2.0} \\
\text { inches) }\end{array}\end{array}$ & \\
\hline $21 \%$ & $9 \%$ & $17 \%$ & $24 \%$ \\
\hline $17 \%$ & $2 \%$ & $11 \%$ & $17 \%$ \\
\hline $17 \%$ & $9 \%$ & $14 \%$ & $18 \%$ \\
\hline $8 \%$ & $19 \%$ & $12 \%$ & $3 \%$ \\
\hline $9 \%$ & $14 \%$ & $11 \%$ & $11 \%$ \\
\hline $13 \%$ & $4 \%$ & $9 \%$ & $17 \%$ \\
\hline $5 \%$ & $6 \%$ & $5 \%$ & $4 \%$ \\
\hline $4 \%$ & $7 \%$ & $5 \%$ & $2 \%$ \\
\hline $2 \%$ & $5 \%$ & $3 \%$ & $1 \%$ \\
\hline $0 \%$ & $6 \%$ & $2 \%$ & $0 \%$ \\
\hline $0 \%$ & $4 \%$ & $2 \%$ & $0 \%$ \\
\hline $0 \%$ & $3 \%$ & $1 \%$ & $0 \%$ \\
\hline $2 \%$ & $1 \%$ & $1 \%$ & $1 \%$ \\
\hline $1 \%$ & $2 \%$ & $1 \%$ & $1 \%$ \\
\hline $0 \%$ & $3 \%$ & $1 \%$ & $0 \%$ \\
\hline $0 \%$ & $2 \%$ & $1 \%$ & $0 \%$ \\
\hline $0 \%$ & $1 \%$ & $0 \%$ & $0 \%$ \\
\hline $0 \%$ & $1 \%$ & $0 \%$ & $0 \%$ \\
\hline $0 \%$ & $1 \%$ & $0 \%$ & $0 \%$ \\
\hline $0 \%$ & $1 \%$ & $0 \%$ & $0 \%$ \\
\hline $0 \%$ & $1 \%$ & $0 \%$ & $0 \%$ \\
\hline $0 \%$ & $0 \%$ & $0 \%$ & $0 \%$ \\
\hline $0 \%$ & $0 \%$ & $0 \%$ & $0 \%$ \\
\hline $0 \%$ & $0 \%$ & $0 \%$ & $0 \%$ \\
\hline $100 \%$ & $100 \%$ & $100 \%$ & $100 \%$ \\
\hline
\end{tabular}


Table III.3. Total trees and trees per acre by species and size class for the VTR review area.

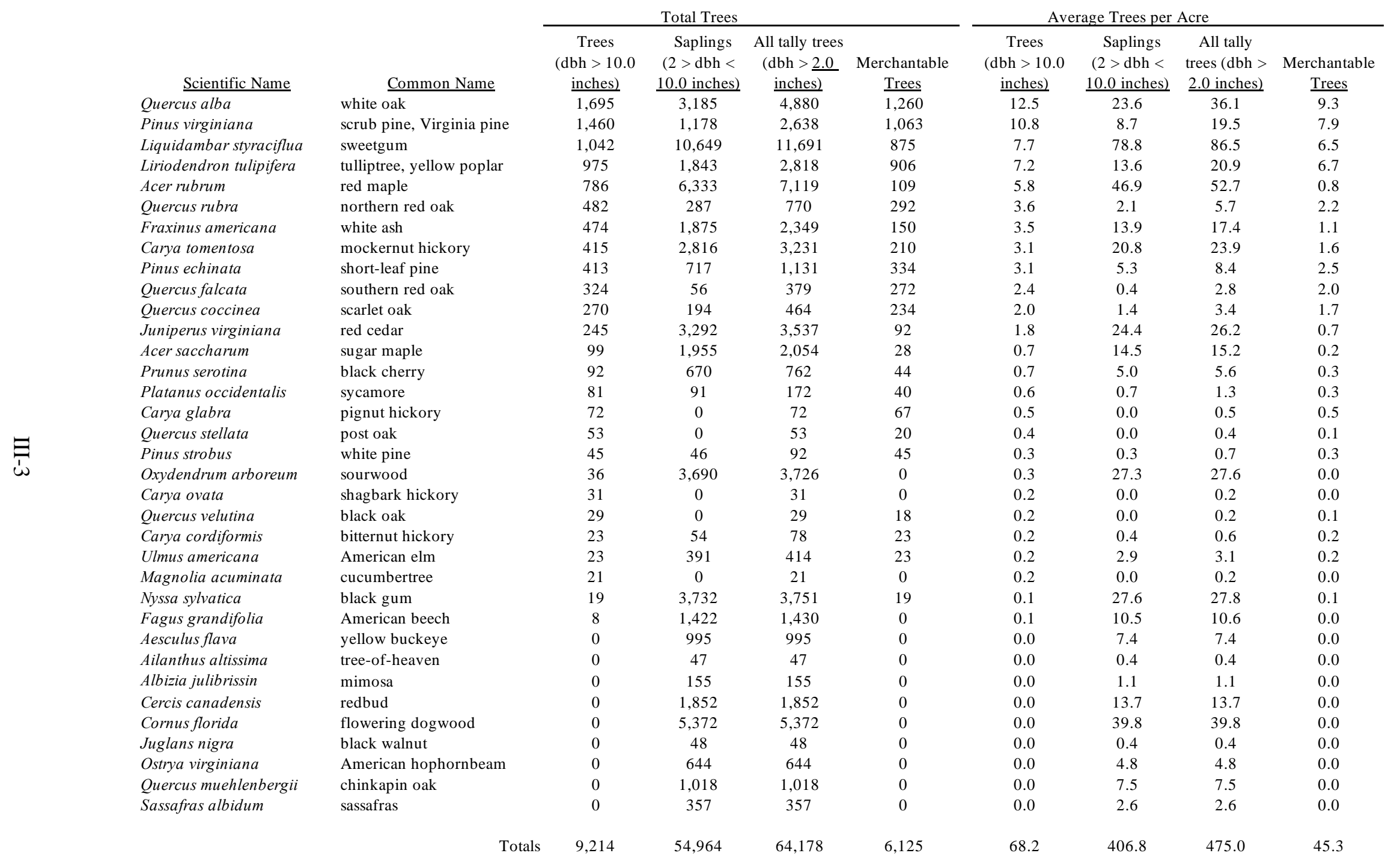


Table III.4. Total and per acre merchantable volume of timber by species for the VTR review area.

$\underline{\text { Scientific Name }}$

Quercus alba

Liriodendron tulipifera

Pinus virginiana

Liquidambar styraciflua

Quercus rubra

Quercus falcata

Quercus coccinea

Pinus echinata

Carya tomentosa

Fraxinus americana

Platanus occidentalis

Acer rubrum

Pinus strobus

$\quad$ Juniperus virginiana

Carya glabra

Quercus velutina

Acer saccharum

Prunus serotina

Nyssa sylvatica

Quercus stellata

Ulmus americana

Carya cordiformis
2011 Volume (board feet)

$\quad$ Common Name
white oak
tulliptree, yellow poplar
scrub pine, Virginia pine
sweetgum
northern red oak
southern red oak
scarlet oak
short-leaf pine
mockernut hickory
white ash
sycamore
red maple
white pine
red cedar
pignut hickory
black oak
sugar maple
black cherry
black gum
post oak
American elm
bitternut hickory

\begin{tabular}{c} 
Tract Total \\
\hline 174,201 \\
152,698 \\
97,584 \\
80,285 \\
47,388 \\
38,024 \\
32395 \\
27,221 \\
19,016 \\
15,928 \\
13,419 \\
11,507 \\
10,349 \\
7,672 \\
4,497 \\
4,381 \\
3,750 \\
3,007 \\
2,498 \\
1,518 \\
1491 \\
1,488
\end{tabular}

Totals

\begin{tabular}{c} 
Average per Acre \\
\hline 1,289 \\
1,130 \\
722 \\
594 \\
351 \\
281 \\
240 \\
201 \\
141 \\
118 \\
99 \\
85 \\
77 \\
57 \\
33 \\
32 \\
28 \\
22 \\
18 \\
11 \\
11 \\
11 \\
5,554
\end{tabular}

Estimated 2019 Volume (board feet)

\begin{tabular}{c} 
Tract Total \\
\hline 220,673 \\
193,433 \\
123,617 \\
101,703 \\
60,029 \\
48,167 \\
41,037 \\
34,483 \\
24,090 \\
0 \\
16,999 \\
14,577 \\
13,109 \\
9,719 \\
5,696 \\
5,550 \\
4,751 \\
3,809 \\
3,165 \\
1,923 \\
1,889 \\
1,885 \\
930,304
\end{tabular}

Percent of

$\underline{\text { Total }}$

$23.2 \%$

$20.4 \%$

$13.0 \%$

$10.7 \%$

$6.3 \%$

$5.1 \%$

$4.3 \%$

$3.6 \%$

$2.5 \%$

$2.1 \%$

$1.8 \%$

$1.5 \%$

$1.4 \%$

$1.0 \%$

$0.6 \%$

$0.6 \%$

$0.5 \%$

$0.4 \%$

$0.3 \%$

$0.2 \%$

$0.2 \%$

$0.2 \%$ 
Table III.5. Total and per acre merchantable volume of timber by genus for the VTR review area.

\begin{tabular}{|c|c|c|c|c|c|c|}
\hline \multirow[b]{2}{*}{$\underline{\text { Scientific Name }}$} & \multirow[b]{2}{*}{ Common Name } & \multicolumn{3}{|c|}{2011 Volume (board feet) } & \multicolumn{2}{|c|}{ Estimated 2019 Volume (board feet) } \\
\hline & & Tract Total & Average per Acre & $\begin{array}{l}\text { Percent of } \\
\text { total }\end{array}$ & Tract Total & Average per Acre \\
\hline Acer & maple & 15,258 & 113 & $2.0 \%$ & 19,328 & 143 \\
\hline Carya & hickory & 25,001 & 185 & $3.3 \%$ & 31,670 & 234 \\
\hline Fraxinus & ash & 15,928 & 118 & $2.1 \%$ & 0 & 0 \\
\hline Juniperus & red cedar & 7,672 & 57 & $1.0 \%$ & 9,719 & 72 \\
\hline Liquidambar & sweetgum & 80,285 & 594 & $10.7 \%$ & 101,703 & 753 \\
\hline Liriodendron & tulliptree, yellow poplar & 152,698 & 1,130 & $20.4 \%$ & 193,433 & 1,432 \\
\hline Nyssa & gum & 2,498 & 18 & $0.3 \%$ & 3,165 & 23 \\
\hline Pinus & pine & 135,154 & 1,000 & $18.0 \%$ & 171,210 & 1,267 \\
\hline Platanus & sycamore & 13,419 & 99 & $1.8 \%$ & 16,999 & 126 \\
\hline Prunus & cherry & 3,007 & 22 & $0.4 \%$ & 3,809 & 28 \\
\hline Quercus & oak & 297,907 & 2,205 & $39.7 \%$ & 377,379 & 2,793 \\
\hline Ulmus & elm & 1491 & 11 & $0.2 \%$ & 1,889 & 14 \\
\hline & Totals & 750,319 & 5,554 & $100 \%$ & 930,304 & 6,886 \\
\hline
\end{tabular}




\section{Table III.6. Largest trees of each species for the VTR review area.}

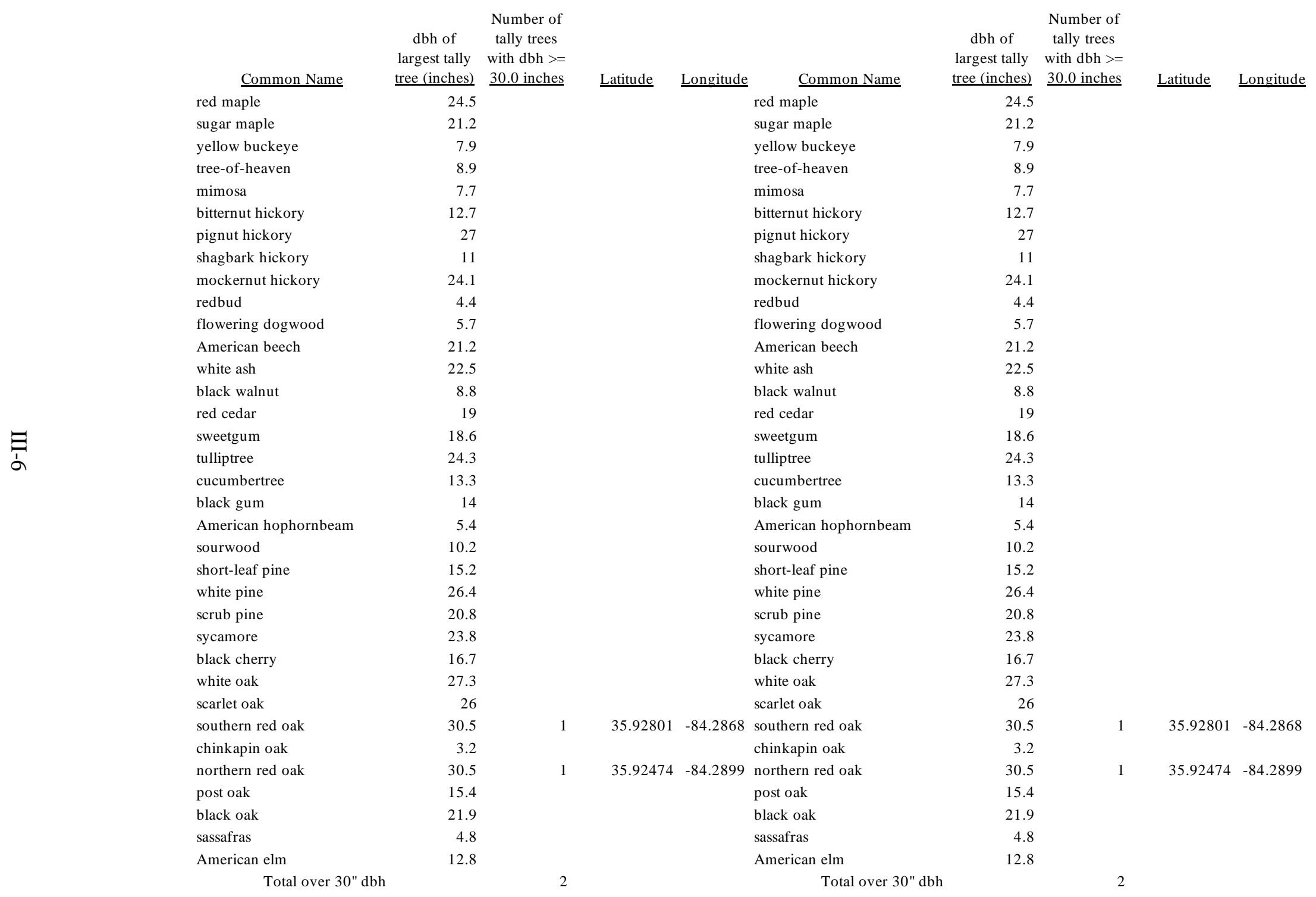

